\title{
Bedeutung des cytosolischen Teils des großen Hüllproteins für die Umhüllung des Hepatitis B Virus Nukleokapsids
}

\author{
Dissertation \\ zur Erlangung des Doktorgrades \\ der Mathematisch-Naturwissenschaftlichen Fakultäten \\ der Georg-August-Universität zu Göttingen
}

vorgelegt von

Michaela Schläger

aus Kassel 
D7

Referent:

Prof. Dr. A. Zeeck

Korreferent:

Prof. Dr. L. Fitjer

Tag der mündlichen Prüfung: 


\section{Inhaltsverzeichnis}

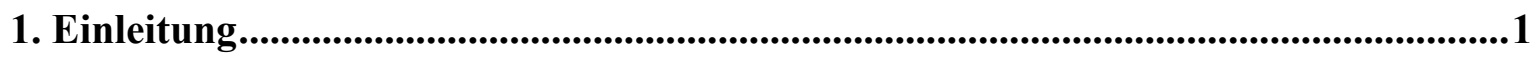

1.1 Die Familie der Hepadnaviridae ……………………………………………....

1.2 Das humane Hepatitis B Virus ............................................................................

1.3 Die Struktur des Hepatitis B Virus ........................................................................

1.4 Infektionszyklus des Hepatitis B Virus .....................................................................

1.5 Morphogenese des Hepatitis B Virus ..........................................................................

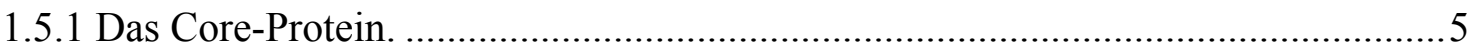

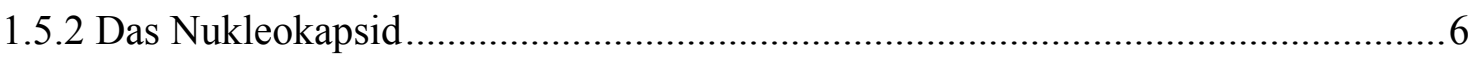

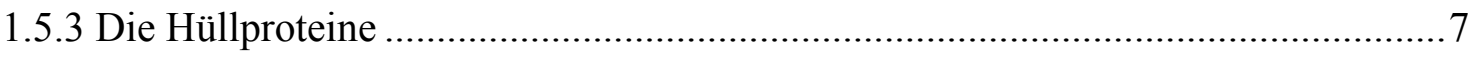

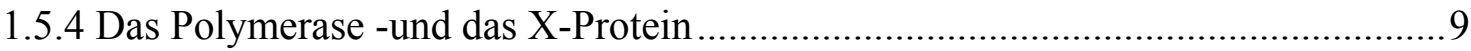

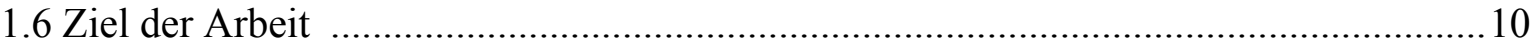

2. Allgemeiner Teil............................................................................................................... 11

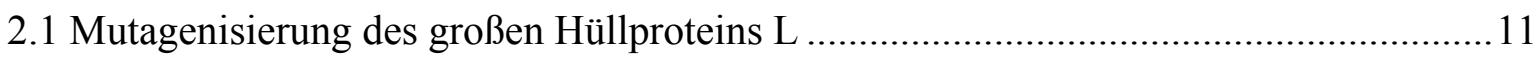

2.1.1 Exonukleolytische Verkürzung von Plasmid-DNA mit Bal31 ..............................11

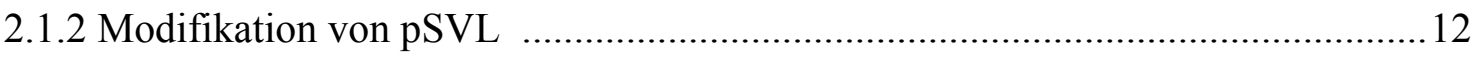

2.1.3 Restriktionsanalyse einer Auswahl von Plasmiden ...............................................13

2.1.4 Sequenzierung einer Auswahl von Mutanten........................................................14

2.2 Erste Selektion einer Auswahl von L-Protein Mutanten in Zellkultur ...........................15

2.2.1 Nachweis der Hüllproteinbildung in Zelllysaten.................................................15

2.2.2 Cotransfektion von COS7-Zellen mit pSVBX24H …………............................ 17

2.3 Erweiterte Mutagenisierung des L-Proteins ..................................................................19

2.3.1 Einführung von Deletionen mittels PCR .............................................................. 19

2.4 Expression deletierter L-Proteine in COS7-Zellen.......................................................21

2.4.2 Überprüfung der Sezernierung der deletierten L-Konstrukte.................................23

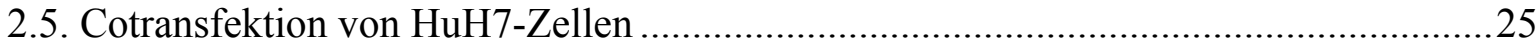

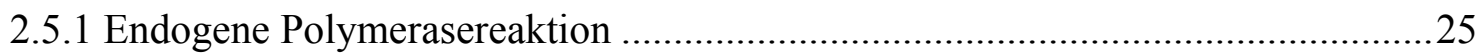

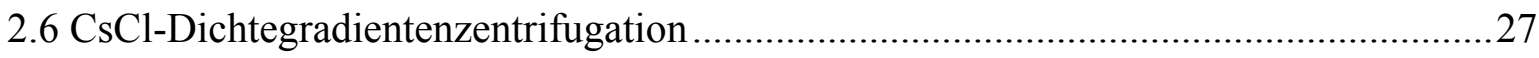

2.7 Zusammenfassung der bisherigen Daten ...............................................................29

2.8 Konstruktion von Deletionsplasmiden im Bereich

zwischen AS 220 und 237 mittels PCR ……………………..................................31 


\subsection{1 Überprüfung der Konstrukte auf Expression der L-Proteine} in COS7-Zellen

2.8.2 Überprüfung der Sezernierung deletierter L-Proteine nach

Cotransfektion von COS7-Zellen

2.9 Nachweis kompletter Virionen durch endogene Polymerasereaktion

nach Cotransfektion von HuH7-Zellen .35

2.10 Bedeutung der in das L-Protein eingeführten Deletionen

für die Sekretion subviraler Partikel 37

2.11 Einfluss der deletierten L-Proteine auf die Virusbildung 41

2.12 Auswirkung des durch die eingeführten Deletionen veränderten Abstands zwischen ER-Membran und der Domäne von AS 98-124 .42

2.13 Ausblick 44

3. Zusammenfassung 45

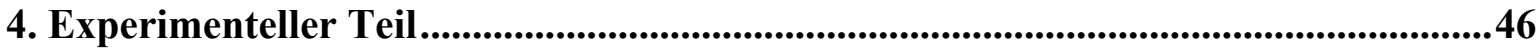

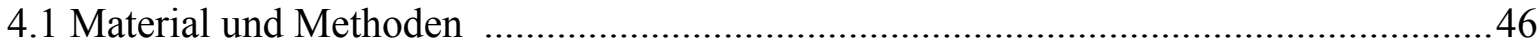

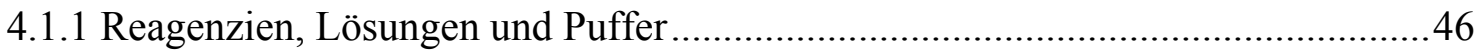

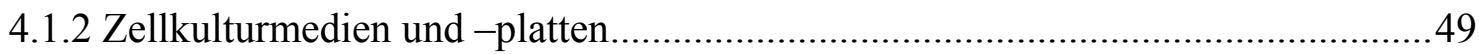

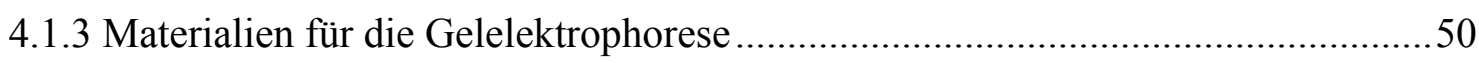

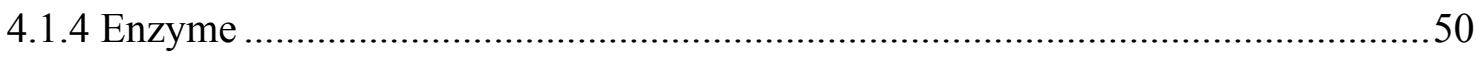

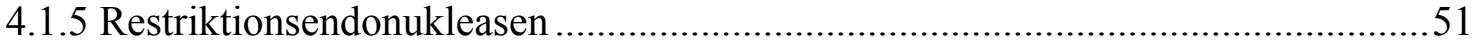

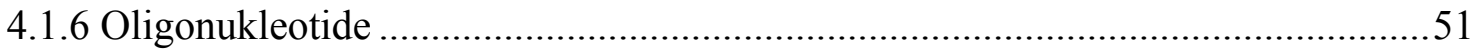

4.1.7 Längenstandards für Gelelektrophoresen ........................................................52

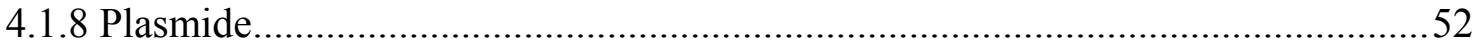

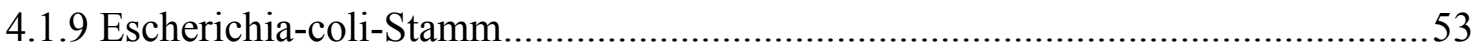

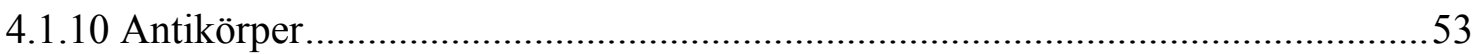

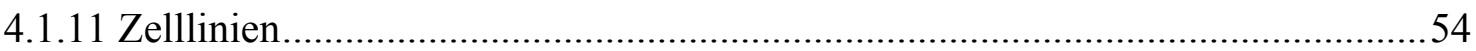

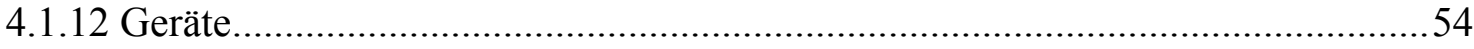

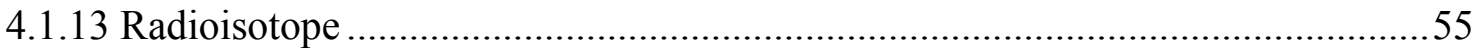

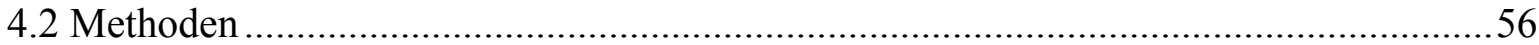

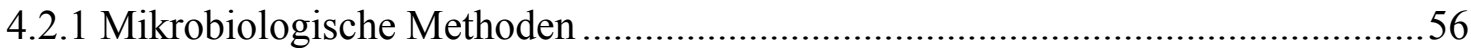

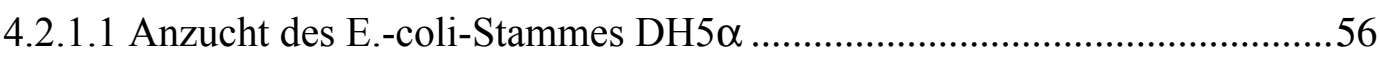

4.2.1.2 Herstellung kompetenter E.-coli-Zellen ...............................................56 
4.2.1.3 Transformation von E.-coli-Zellen mit Plasmid-DNA .............................57

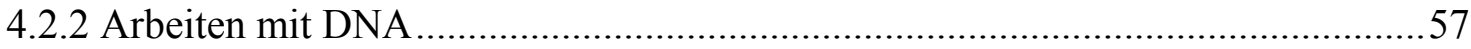

4.2.2.1 Isolierung von DNA in analytischem Maßstab .....................................57

4.2.2.2 Isolierung von DNA in präparativem Maßstab .......................................58

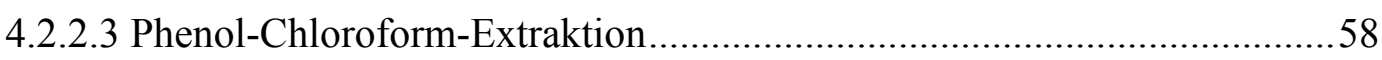

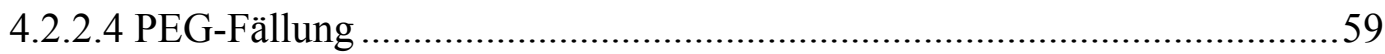

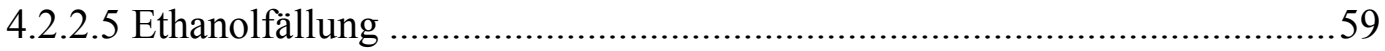

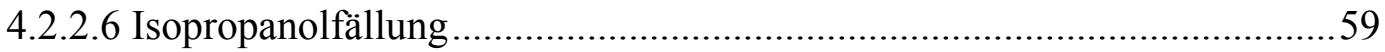

4.2.2.7 Konzentrationsbestimmung von DNA und Proteinen .............................59

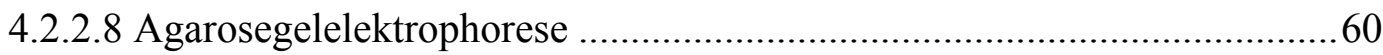

4.2.2.9 Spalten von DNA mittels Restriktionsendonukleasen.............................61

4.2.2.10 Behandlung mit Exonuklease Bal31 ...................................................62

4.2.2.11 Behandlung mit Mung Bean-Nuklease.................................................63

4.2.2.12 DNA-Extraktion aus Agarosegelen ......................................................63

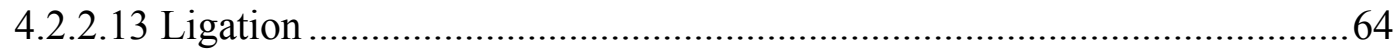

4.2.2.14 Polymerase-Kettenreaktion

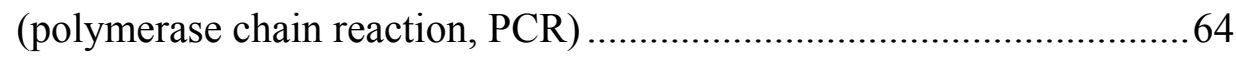

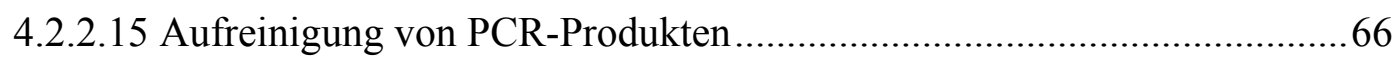

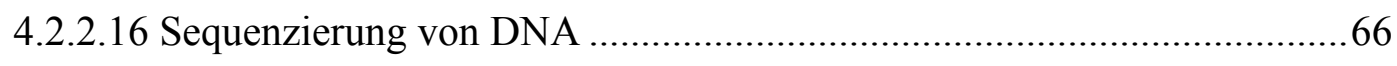

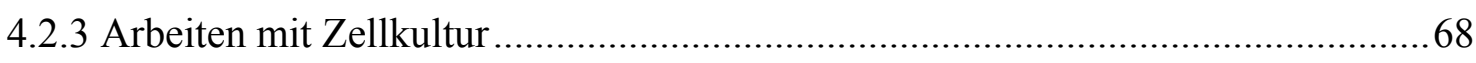

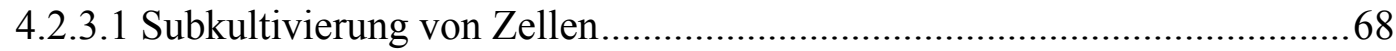

4.2.3.2 Transiente Transfektion eukaryontischer Zellen....................................69

4.2.3.3 Transfektion von COS7-Zellen mit DEAE-Dextran.................................69

4.2.3.4 Transfektion von HuH7-Zellen

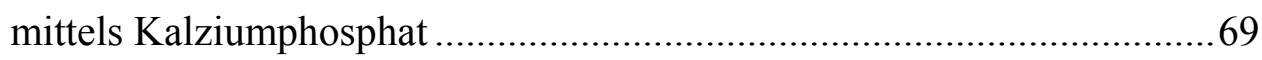

4.2.3.5 Bestimmung des HBsAg-Titers ..................................................... 70

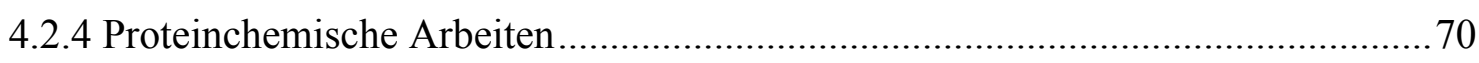

4.2.4.1 Ernte und Aufreinigung des Zellkulturmediums ....................................70

4.2.4.2 Herstellung von Zelllysaten ................................................................ 70

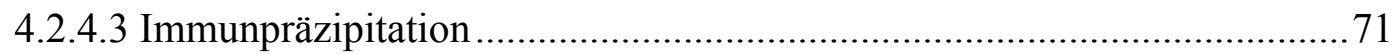

4.2.4.4 Radioaktive metabolische Markierung von Zellen

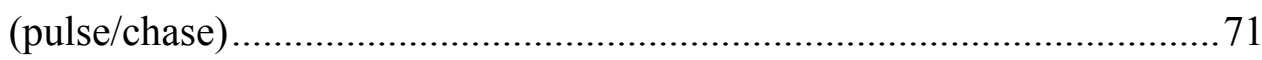

4.2.4.5 Herstellung von SDS-Polyacrylamidgelen .......................................... 72

4.2.4.6 SDS-Polyacrylamidgelelektrophorese ..............................................72 


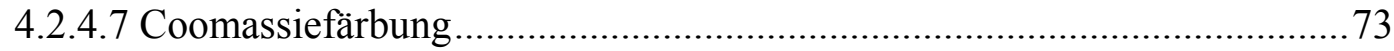

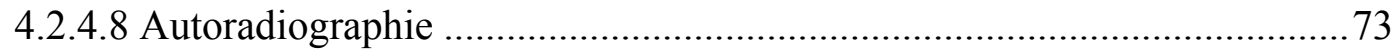

4.2.4.9 Endogene Polymerasereaktion (EPR) ................................................. 73

4.2.4.10 Anreicherung von Virionen durch CsCl-Dichtegradientenzentrifugation .............................................................................. 74

4.2.4.11 Dichtebestimmung des CsCl-Gradienten ............................................. 74

4.2.4.12 Dialyse von CsCl-Fraktionen............................................................. 75

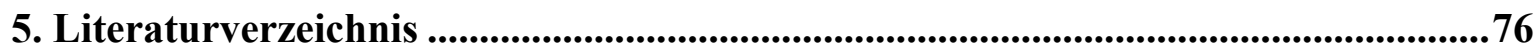

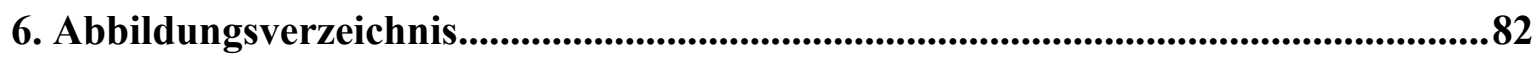

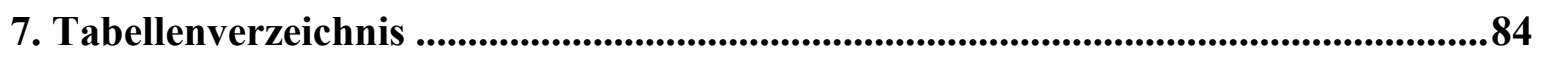




\section{Abkürzungen}

Grundsätzlich werden die international üblichen chemischen Symbole und Abkürzungen der SI-Einheiten (Systeme International d'Unites) benutzt. Die in dieser Arbeit verwendeten Ein-Buchstaben-Notierungen für Aminosäuren sowie Abkürzungen für Nukleinsäure-Bausteine und alle physikalischen Größen entsprechen der Konvention der „International Union for Biochemistry“.

\begin{tabular}{|c|c|c|c|}
\hline $\mathbf{A}$ & Adenosin & d.h. & das heißt \\
\hline $\mathrm{Ag}$ & Antigen & DMSO & Dimethylsulfoxid \\
\hline $\mathrm{Ak}$ & Antikörper & DNA & Desoxyribonukleinsäure \\
\hline Amp & Ampicillin & dNTP & Desoxynukleotid-5'- \\
\hline anti- & gegen & & triphosphat \\
\hline APS & Ammoniumperoxodisulfat & DTT & Dithiotreitol \\
\hline ATP & Adenosin-5'-triphosphat & dTTP & $\begin{array}{l}\text { Desoxythymidin-5' - } \\
\text { triphosphat }\end{array}$ \\
\hline bidest & doppelt destilliert & & \\
\hline $\mathrm{Bp}$ & Basenpaare & E. coli & Escherichia coli \\
\hline BSA & Rinderserumalbumin & EDTA & Ethylendiamintetraacetat \\
\hline bzw. & beziehungsweise & ELISA & $\begin{array}{l}\text { Enzyme Linked Immuno } \\
\text { sorbent Assay }\end{array}$ \\
\hline $\mathbf{C}$ & Cytosin & ER & Endoplasmatisches \\
\hline ca. & circa & & Retikulum \\
\hline \multirow[t]{2}{*}{$\mathrm{Ci}$} & Curie $\left(1 \mathrm{Ci}=3,7 \times 10^{10}\right.$ & & \\
\hline & Zerfälle pro Sekunde) & FKS & fötales Kälberserum \\
\hline \multirow[t]{2}{*}{ Corp. } & Corporation & & \\
\hline & & G & Guanin \\
\hline D & Dalton & $\mathrm{g}$ & Gramm \\
\hline dATP & $\begin{array}{l}\text { Desoxyadenosin-5' - } \\
\text { triphosphat }\end{array}$ & GTP & Guanosin-5'-triphosphat \\
\hline \multirow[t]{2}{*}{$\mathrm{dCTP}$} & Desoxycytosin-5'- & $\mathbf{h}$ & Stunde \\
\hline & triphosphat & $\mathrm{HBc}$ & Hepatitis B Core \\
\hline \multirow[t]{2}{*}{ dGTP } & Desoxyguanosin-5'- & HBs & Hepatitis B Surface \\
\hline & triphosphat & HBV & Hepatitis B Virus \\
\hline
\end{tabular}




\begin{tabular}{|c|c|c|}
\hline $\mathbf{k D}$ & Kilodalton & negativer dekadisch \\
\hline $\mathrm{kB}$ & Kilobasen & Logarithmus der Wasser- \\
\hline
\end{tabular}

LB Luria Broth

$\begin{array}{llll}\text { M } & \text { molar } & \text { RNAse } & \text { Ribonuklease } \\ \mathrm{m} & \text { milli,Meter } & \text { RT } & \text { Raumtemperatur }\end{array}$

$\mu \quad$ mikro

$\mathrm{mA} \quad$ Milliampere

SDS Natriumdodecylsulfat

med. medizinisch

sek. Sekunde

min. Minuten

mol $6,023 \times 10^{23}$ Teilchen

T

Thymin

MOPS 3-(N-Morpholino)-

TAE Tris-Acetat-EDTA-Puffer

Propansulfonsäure

TBE

Tris-Borat-EDTA-Puffer

mRNA messanger RNA

TE

Tris-EDTA-Puffer

TEMED N,N,N', $\mathrm{N}^{\prime}-$

NP40 Nonidet P40

Tris

tetraethylendiamin

nt Nukleotid

Trishydroxymethyl-

aminomethan

O.D. optische Dichte

ORF offener Leserahmen

U Einheit („Unit)

(,open reading frame")

UpM Umdrehungen pro Minute

ori origin of replication

UV

ultraviolett

P Protein

PAG Polyacrylamidgel

V

Volt

PAGE Polyacrylamidgel-

elektrophorese

$\mathbf{w} / \mathrm{v}$

Gewicht pro Volumen

PBS phosphatgepufferte

Salzlösung

z.B.

zum Beispiel

PCR Polymerasekettenreaktion

PEG Polyethylenglycol 
Aminosäuren

$\begin{array}{lllccl}\text { A } & \text { Ala } & \text { Alanin } & \text { M } & \text { Met } & \text { Methionin } \\ \text { C } & \text { Cys } & \text { Cystein } & \text { N } & \text { Asn } & \text { Asparagin } \\ \text { D } & \text { Asp } & \text { Asparaginsäure } & \text { P } & \text { Pro } & \text { Prolin } \\ \text { E } & \text { Glu } & \text { Glutaminsäure } & \text { Q } & \text { Gln } & \text { Glutamin } \\ \text { F } & \text { Phe } & \text { Phenylalanin } & \text { R } & \text { Arg } & \text { Arginin } \\ \text { G } & \text { Gly } & \text { Glycin } & \text { S } & \text { Ser } & \text { Serin } \\ \text { H } & \text { His } & \text { Histidin } & \text { T } & \text { Thr } & \text { Threonin } \\ \text { I } & \text { Ile } & \text { Isoleucin } & \text { V } & \text { Val } & \text { Valin } \\ \text { K } & \text { Lys } & \text { Lysin } & \text { W } & \text { Trp } & \text { Tryptophan } \\ \text { L } & \text { Leu } & \text { Leucin } & \text { Y } & \text { Tyr } & \text { Tyrosin }\end{array}$




\section{Einleitung}

\subsection{Die Familie der Hepadnaviridae}

Das Hepatitis B Virus (HBV) gehört taxonomisch zur kleinen Virusfamilie der Hepadnaviridae, umhüllter hepatotroper DNA-Viren, die sich durch ihren Replikationsmechanismus über ein RNA-Intermediat und ihr begrenztes Wirtsspektrum auszeichnen. Die Hepadnaviren sind DNA-Viren, die sich spezifisch in Hepatozyten vermehren. Sie werden unterteilt in Hepadnaviren der Säugetiere (Orthohepadnaviridae) und der Vögel (Avihepadnaviridae). Neben dem Hepatitis B Virus, das außer einigen höheren Primaten nur den Menschen infiziert, gehören auch die Hepatitisviren des Waldmurmeltiers (,woodchuck hepatitis virus“, WHV ${ }^{[1]}$ ), des Erdhörnchens (,ground squirrel hepatitis virus“, GSHV ${ }^{[2]}$ ) und, vor kurzem erst entdeckt, des Wollaffen (,,woolly monkey hepatitis virus“, $\mathrm{WMHV}^{[3]}$ ) zu den Orthohepadnaviren.

Das Hepatitis B Virus der Pekingente (,duck hepatitis B virus“, DHBV ${ }^{[4]}$ ) und das des Graureihers (,heron hepatitis B virus“, $\mathrm{HHBV}^{[5]}$ ) werden zusammengefaßt zu den Avihepadnaviren.

\subsection{Das humane Hepatitis B Virus}

Die durch das humane Hepatitis B Virus hervorgerufene Infektion beim Menschen zeigt unterschiedliche klinische Manifestationen. Sie reichen von der inapparenten Verlaufsform in etwa $50 \%$ der Fälle bis zur fulminanten Hepatitis mit Todesfolge ${ }^{[6]}$. Während in den meisten Fällen die Infektion mit nachfolgender Immunität ausheilt nimmt sie bei ca. $10 \%$ der Infizierten einen chronischen Verlauf. In diesen Fällen ist das Risiko, ein hepatozelluläres Karzinom zu entwickeln ${ }^{[7]}$ oder an Leberzirrhose zu erkranken, etwa 200 mal höher als bei Nichtinfizierten. Mit weltweit über 350 Millionen chronisch infizierten Menschen ist das HBV einer der bedeutensten viralen Krankheitserreger. Das Virus infiziert durch parenterale Übertragung mit infiziertem Blut, Blutderivaten oder anderen Köperflüssigkeiten und kann auch peri- oder postnatal Säuglinge infizieren, deren Immunsystem noch kaum entwickelt ist. Daher verlaufen hier die Infektionen fast 
ausschließlich chronisch. Diese chronisch Infizierten stellen ein Reservoir dar, über das eine weitere Verbreitung erfolgen kann.

\subsection{Die Struktur des Hepatitis B Virus}

Das sphärische Hepatitis B Virus-Partikel besteht aus einem $30 \mathrm{~nm}$ großen ikosaedrischen Nukleokapsid, das sich aus monomeren Untereinheiten, den Coreproteinen, die ein Molekulargewicht von $21 \mathrm{kD}$ besitzen ${ }^{[8]}$, zusammensetzt. Es enthält das Virus-Genom, bestehend aus einer zirkulären, partiell doppelsträngingen $\mathrm{DNA}^{[9]}$ und eine DNAPolymerase $^{[10]}$. Umschlossen wird das Nukleokapsid von einer lipidhaltigen Hülle, welche viruskodierende Oberflächenproteine enthält ${ }^{[11]}$. Dieses ca. $42 \mathrm{~nm}$ große infektiöse Partikel wird nach seinem Entdecker auch Dane-Partikel genannt ${ }^{[12]}$.

Zudem sind im Serum infizierter Individuen auch subvirale, nicht infektiöse Partikel nachweisbar. Sie bestehen nur aus viralen Hüllproteinen und Lipid. Ihre Konzentration ist $10^{3}$ - bis $10^{5}$-fach höher als die der Virionen. Sie haben einen Durchmesser von $20 \mathrm{~nm}$ und liegen in sphärischer oder filamentöser Form vor, wobei die Länge der Filamente zwischen $50 \mathrm{~nm}$ und $1 \mu \mathrm{m}$ variiert. Man spricht auch von HBsAg-Partikeln, da die Oberflächenproteine, aus denen sie bestehen, Antigendeterminanten enthalten, die bei den meisten Infizierten eine starke Immunantwort hervorrufen ${ }^{[13]}$.

\subsection{Infektionszyklus des Hepatitis B Virus}

Der Mechanismus der Virusaufnahme ist bisher noch nicht geklärt. Es wird vermutet, dass es sich um einen Rezeptor-vermittelten Prozeß handelt, bei dem ein Bereich des großen Hüllproteins an einen oder mehrere zelluläre Rezeptoren bindet ${ }^{[14]}$ und das Virus auf diese Art in die Zelle eindringen kann. Es konnte jedoch bisher keiner der zahlreichen Rezeptorkandidaten wie beispielsweise Fibronektin, Apolipoprotein $\mathrm{H}$ und andere sicher bestätigt werden ${ }^{[15]}$. Das Nukleokapsid gelangt anschließend durch einen wahrscheinlich pH-unabhängigen Mechanismus in das Zytoplasma der Wirtszelle ${ }^{[16]}$, wo es an der Kernmembran zerfällt ${ }^{[17]}$, wodurch das virale Genom wahrscheinlich als DNA-PolymeraseKomplex, wie Untersuchungen am WHV zeigten, in den Zellkern gelangt ${ }^{[18]}$. Durch unterschiedliche zelluläre Enzyme wird das Genom dort in die kovalent geschlossene Form 
(ccc-DNA) überführt ${ }^{[19]}$, von der die unterschiedlich langen RNA-Moleküle von der zellulären RNA-Polymerase II transkibiert werden. Diese besitzen ein identisches 3'-Ende, da das zirkuläre Virusgenom nur ein Polyadenylierungssignal enthält. Die virale Polymerase und das Core-Protein sind die Translationsprodukte der 3,5 kB großen mRNA, die über ca. 120 Bp einen terminal redundanten Bereich aufweist ${ }^{[20]}$. Diese virale RNA von übergenomischer Länge enthält ein Verpackungssignal $\varepsilon$ auf RNA-Sekundärstrukturebene, das von der viralen Polymerase erkannt und gebunden wird ${ }^{[21]}$. Hierdurch wird die Verpackung des Prägenom-Polymerase-Komplexes durch Coreproteine zu einem Nukleokapsid initiiert. Im Inneren des Partikels erfolgt die Synthese des viralen Genoms durch die reverse Transkriptionsreaktion ${ }^{[22]}$, wobei $\varepsilon$ als Template für einen kurzen DNAPrimer und somit als Replikationsursprung dient ${ }^{[23]}$. Mit der Synthese des Plusstranges geht die Degradation des RNA-Stranges einher. Die Zweitstrangsynthese endet an einer nicht genau definierten Stelle. Das Genom in fertigen Virionen ist daher nur partiell doppelsträngig. „Reife“ Kapside, die diese partiell doppelsträngige DNA enthalten, im Gegensatz zu „unreifen“ Kapsiden, in denen sich das RNA-Prägenom befindet, können im Infektionszyklus zwei unterschiedlichen Wegen folgen.

In der frühen Phase der Infektion vermehren sie hauptsächlich die ccc-DNA im Zellkern, indem sie zu diesem zurück transportiert werden ${ }^{[24]}$, dort zerfallen, und das Genom in den Kern eingeschleust wird.

In der späten Phase hingegen interagiert das Nukleokapsid mit den Hüllproteinen, die von einer 2,4 kB und einer $2,1 \mathrm{kB}$ großen mRNA translatiert wurden. Die Hüllproteine durchspannen die Membran des Endoplasmatischen Retikulums (ER). Das Kapsid gelangt durch Knospung in dessen Lumen, wird umhüllt und verläßt als Virion die Zelle auf sekretorischem $\mathrm{Weg}^{[25]}$. 


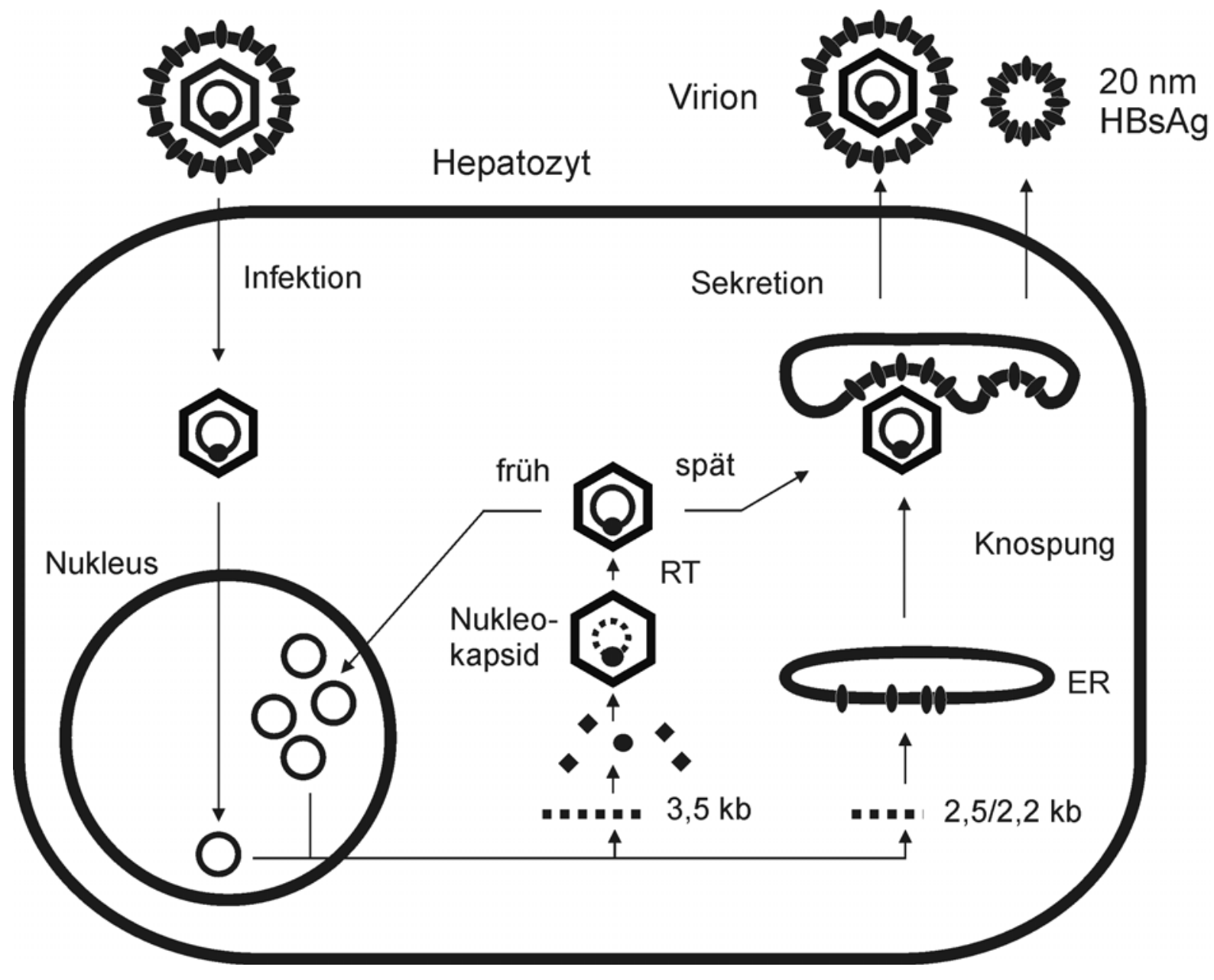

Abb.1.1: Infektionszyklus des Hepatitis B Virus

Bei der Infektion der Leberzelle wird das virale Genom freigesetzt und etabliert sich als Episom im Zellkern. Aus dem 3,5 kB großen Prägenom (gestrichelte Linie), der viralen Polymerase $(\bullet)$ und dem Core-Protein $(\bullet)$ entsteht das Nukleokapsid, in dem die DNASynthese durch reverse Transkription stattfindet. In der frühen Phase der Infektion gelangt das Genom wieder in den Zellkern. In der späten Phase wird das Kapsid an der Membran des ER von den Hüllproteinen umhüllt. Die Hüllproteine werden von einer 2,5 kB und 2,2 kB großen mRNA translatiert. Umhüllte Kapside werden über den GolgiApparat als infektiöse Viren sekretiert. Neben den Virionen werden außerdem sogenannte subvirale nicht infektiöse Partikel sekretiert, die nur aus Hüllproteinen und Lipiden bestehen.

\subsection{Morphogenese des Hepatitis B Virus}

Ein essentieller Schritt im Vermehrungszyklus des Virus ist die Bildung von infektiösen Viruspartikeln. Zum besseren Verständnis dieses komplexen Vorganges müssen zunächst die daran beteiligten Strukturproteine näher charakterisiert werden. 


\subsubsection{Das Coreprotein}

Der Core-ORF kodiert für zwei verschieden große Proteine, das Präcore- und das CoreProtein, die einen unterschiedlichen N-Terminus besitzen. Beide bilden eine unterschiedliche Antigenität aus, die als $\mathrm{HBeAg}$ und $\mathrm{HBcAg}$ bezeichnet wird.

Das $\mathrm{HBeAg}$, das vom ersten Initiationskodon aus translatiert wird, ist $25 \mathrm{kD}$ groß und besitzt am N-Terminus gegenüber dem Coreprotein zusätzliche 29 Aminosäuren, die durch den PräC-Bereich des Core-ORFs kodiert werden. Der Präcore-Bereich besitzt eine Signalsequenz, die bei der Translokation ins ER-Lumen abgespalten wird ${ }^{[26]}$. In einem dem ER nachgelagerten Kompartiment ${ }^{[27]}$ findet am C-Terminus eine weitere Prozessierung statt, bevor das $16 \mathrm{kD}$ große Protein sezerniert wird. Das $\mathrm{HBeAg}$ ist weder für die Virusbildung noch für die Infektiosität notwendig ${ }^{[28]}$, scheint aber die infizierte Leberzelle vor einer immunologischen Reaktion zu schützen ${ }^{[29]}$.

Das 21 kD große Coreprotein besteht je nach Subtyp aus 183 (Subtyp ay) oder 185 (Subtyp ad) Aminosäuren. Es ist Hauptbestandteil des viralen Nukleokapsids und kann funktionell in zwei unterschiedliche Bereiche unterteilt werden. Wie Mutationsanalysen gezeigt haben $^{[30]}$, umfaßt die Domäne, die den ,self- assembly“-Prozeß ermöglicht, die Nterminalen 144 Aminosäuren. Sie enthält außerdem die HBc-Antigendeterminante. Dem basischen, sehr Arginin-reichen C-Terminus wird die Fähigkeit zugeschrieben, DNA binden zu können ${ }^{[31]}$. An den Serin-Resten des C-Terminus kann Phosphorylierung des Proteins ${ }^{[32]}$ erfolgen wie für das $\mathrm{DHBV}^{[33]}$ und $\mathrm{HBV}^{[34]}$ nachgewiesen wurde. Dieser Phosphorylierungszustand könnte bei der Virusmorphogenese eine Rolle spielen. Während DHBV-Coreproteine von Nukleokapsiden, die aus Zellen isoliert wurden, unterschiedlich stark phosphoryliert waren, waren Coreproteine in kompletten Virionen unphosphoryliert ${ }^{[35]}$. Für die Phosphorylierung ist wahrscheinlich eine im Corpartikel verpackte Proteinkinase verantwortlich ${ }^{[36]}$. 


\subsubsection{Das Nukleokapsid}

In der infizierten Zellen ist für die Bildung des Nukleokapsids die Interaktion der Coreproteine mit einem Prägenom-Polymerase-Komplex notwendig ${ }^{[37]}$. Durch Bindung der Polymerase an ein Verpackungssignal $\varepsilon$ am 5'-Ende der prägenomischen RNA wird diese Interaktion initiiert. Das Nukleokapsid wird aus einem Pool von Coreprotein-Dimeren gebildet. Oligomere Zwischenprodukte konnten jedoch nicht nachgewiesen werden. Dieser Vorgang ist von der Konzentration des Coreproteins abhängig.

In anderen Zellsystemen wie z. B. Bakterien ${ }^{[38]}$ oder Insektenzellen ${ }^{[39]}$ wurde eine spontane Bildung von Kapsiden ohne Anwesenheit anderer HBV-Proteine beobachtet.

Cryo-elektronenmikroskopische Untersuchungen von Partikelpräparationen haben gezeigt, dass das Kapsid in zwei unterschiedlichen Formen vorliegt. Zum einen eine kleinere bestehend aus 180 Untereinheiten bzw. 90 Coreprotein-Dimeren und zum anderen eine größere aus 240 Untereinheiten bzw. 120 Coreprotein-Dimeren bestehende Form. Welche der beiden Strukturen an der Virusmorphogenese beteiligt ist, ist nicht bekannt.

Die Oberfläche der Kapside weist „Spikes“ auf und enthält kleine Poren von ca. 2 nm Durchmesser. Durch diese können kleine Moleküle wie ATP und Nukleotide, die für die DNA-Synthese im Inneren der Corepartikel notwendig sind ${ }^{[40]}$, diffundieren. Solche Öffnungen wurden auch bei Kapsiden anderer Viren, in denen Nukleinsäuresynthese stattfindet, beobachtet.

Antikörper-Bindungsstudien und Protease-Schutzversuche haben eine Kartierung dreier Bereiche auf der Oberfläche des Kapsids ermöglicht. Das HBcAg-Epitop um Aminosäure $80^{[41]}$, der Bereich um die Aminosäuren 127 bis $133^{[42]}$ und der C-terminale Bereich um Aminosäure $150^{[43]}$. Letzterer scheint jedoch eine duale Topologie zu besitzen, da er auch für die Nukleinsäure-Bindung notwendig ist ${ }^{[44]}$.

Der N-terminale hydrophobe Teil des Proteins ist kompakt gefaltet und gegenüber Protease-Abbau geschützt ${ }^{[45]}$. Seit 1999 gibt es eine Kristallstruktur des Nukleokapsids ${ }^{[46]}$. 


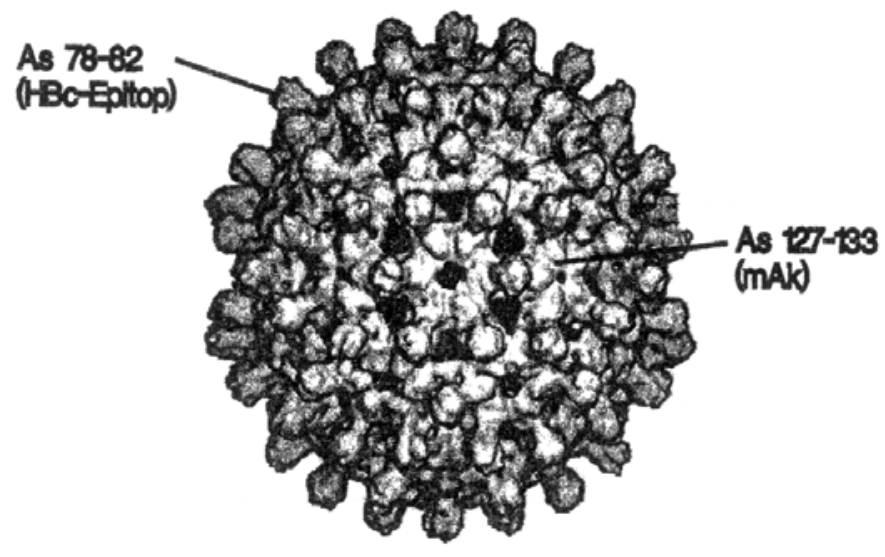

Abb. 1.2: Modell des HBV Corepartikels (modifiziert) ${ }^{[47]}$

Dieses Modell wurde anhand von cryo-elektronenmikroskopischen Daten erstellt. Es zeigt die nach außen gerichtete Domäne des HBV-Nukleokapsids, die durch die Antikörper (anti-HBc und ein monoklonaler Antikörper gegen das Epitop von As 127 bis 133) erkannt werden. Außerdem sind die Poren, die ein Durchtreten kleinerer Moleküle wie z.B. ATP oder Nukleotide ermöglichen, deutlich zu erkennen.

\subsubsection{Die Hüllproteine}

Die drei viralen Hüllproteine SHBs (small hepatitis B surface protein), MHBs (middle hepatitis B surface protein) und LHBs (large hepatitis surface protein), im folgenden als S-, M- und L- Protein bezeichnet, werden von einem offenen Leserahmen kodiert, der drei verschiedene Startkodons und ein gemeinsames Stopkodon besitzt. Unglykosyliert haben sie ein Molekulargewicht von 24 kD (S-Protein), 30 kD (M-Protein) und 39 kD (L-Protein). Das S-Protein enthält zwei hydrophobe Signalsequenzen, welche die kotranslationale Translokation durch die ER-Membran vermitteln. Das Signal I befindet sich kurz hinter dem N-Terminus und wird nicht, wie bei Signalsequenzen sonst üblich, abgespalten ${ }^{[48]}$. Das Signal II, das ebenfalls in die ER-Membran integriert, umfaßt die Aminosäuren 80 bis 100. Die darauf folgenden Aminosäuren sind in das ER-Lumen gerichtet und enthalten das Sspezifische Hauptepitop und eine fakultative N-Glykosylierungsstelle, die aus nicht bekannten Gründen jedoch nur zu $50 \%$ genutzt wird ${ }^{[49]}$. Es liegt daher neben der unglykosylierten Form auch eine glykosylierte Form vor mit einem Molekulargewicht von $27 \mathrm{kD}$.

Das M-Protein weist zusätzlich zum S-Protein N-terminal eine 55 Aminosäure lange PräS2Domäne auf, die ebenfalls durch das Signal II in das ER-Lumen kotranslational transloziert wird. Die Aminosäure $\mathrm{Asn}_{4}$ wird hierbei glykosyliert ${ }^{[50]}$. Die Glykosylierungsstelle der S- 
Domäne wird auch beim M-Protein nur partiell genutzt, so das zwei weitere Formen existieren mit den Molekulargewichten $33 \mathrm{kD}$ und $36 \mathrm{kD}$.

Das L-Protein besteht aus den drei Domänen PräS1, PräS2 und S. Die Länge der Nterminalen PräS1-Sequenz variiert hierbei je nach Subtyp zwischen 108 (ay) oder 119 $(a d)^{[51]}$ Aminosäuren.

Auch bei diesem Protein kommt es zur partiellen Glykosylierung der S-Schleife, so dass auch hier eine zweite Form existiert mit einem Molekulargewicht von $42 \mathrm{kD}^{[52]}$.

Die Topologie des L-Proteins unterscheidet sich von der des S- und M-Proteins. In unterschiedlichen Versuchsansätzen wurde gezeigt, dass der N-terminale Bereich während der Translokation am ER zytosolisch vorliegt und das Signal II die Translokation des C-Terminus bewirkt ${ }^{[53]}$. Bei der Hälfte der L-Proteine kommt es während der Virusmorphogenese zu einer posttranslationalen Translokation ${ }^{[54]}$, so dass ca. $50 \%$ der PräS-Domänen auf dem Viruspartikel nach außen gerichtet sind. Die posttranslationale Translokation, die die duale Topologie des L-Proteins bewirkt, ist ein Prozeß der zuvor bei keinem anderen Virus beschrieben wurde. In früheren Arbeiten konnte gezeigt werden, dass das L-Protein für die Umhüllung des Kapsids und die Entstehung von Viren notwendig ist ${ }^{[54]}$. Es wird vermutet, dass das Protein den direkten Kontakt der Hülle zum Kapsid durch Protein-Protein-Wechselwirkung vermittelt. Außerdem ist bekannt, dass die N-terminalen 253 Aminosäurereste des 400 Aminosäure langen L-Protein zum Cytosol hin orientiert $\operatorname{sind}^{[56]}$. Es konnte außerdem gezeigt werden, dass die N-terminalen 97 Aminosäuren des großen Hüllproteins ohne Funktionsverlust deletiert werden können ${ }^{[57]}$, die Aminosäuren 98 bis 124 jedoch unerlässlich für die Virusbildung sind ${ }^{[59]}$. Weiterhin ist bekannt, dass im Bereich der Aminosäuren 125 bis 171 Penta- bis Dekapeptide durch fremde Peptide ersetzt werden können, ohne das dies die Virusbildung beeinflusst ${ }^{[59]}$. 


\section{ER-Lumen}

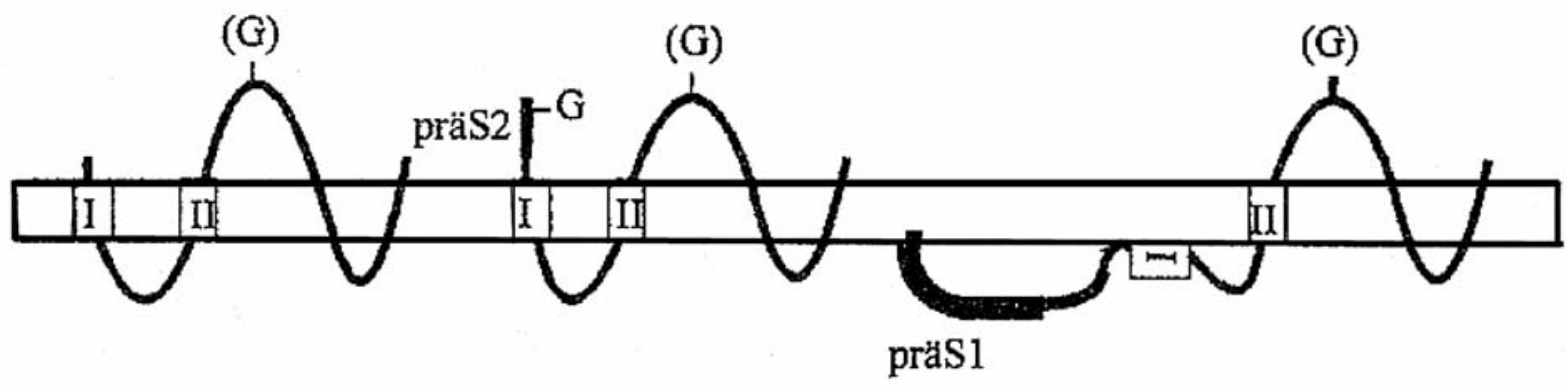

S-Protein

M-Protein

L-Protein

\section{Zytoplasma}

Abb. 1.3: Darstellung der transmembranen Topologie der HBV-Hüllproteine ${ }^{[58]}$

Das S-Protein ist mit zwei Signalsequenzen (I und II) in der ER-Membran (Balken) inseriert und wahrscheinlich durch den hydrophoben C-Terminus zusätzlich in der Membran verankert. Die luminale Schleife ist partiell N-glykosyliert $((\mathrm{G}))$. Das MProtein weist die gleiche Topologie auf, wobei die N-terminale PräS2-Domäne, die an $\mathrm{Asn}_{4}$ N-glykosyliert wird (G), im ER-Lumen liegt. Die PräS-Domänen des L-Proteins sind in der ER-Membran zytosolisch lokalisiert und werden erst später bei einem Teil der L-Proteine in einem posttranslationalen Prozeß durch die Membran transloziert.

\subsubsection{Das Polymerase- und das X-Protein}

Der P-ORF kodiert für das multifunktionale $90 \mathrm{kD}$ große Polymerase-Protein. Es kann in drei verschiedene funktionelle Domänen unterteilt werden. Am N-Terminus liegt die TP (,terminal protein“)-Region (AS 1-180), die als Primer für die Initiation der DNA-Synthese des DNA-Minusstrangs dient. An sie schließt sich eine 160 AS lange Spacer-Region an, die wahrscheinlich keine enzymatische Funktion besitzt, sondern eine Art Gelenk-Bereich darstellt. Die Pol/RT-Domäne, die in der Mitte des P-Proteins liegt und 340 AS groß ist, besitzt RNA- und DNA-abhängige DNA-Polymerase-Aktivität und dient somit als reverse Transkriptase $^{[55]}$. Die C-terminale Region des P-Proteins hat RNAseH-Aktivität und katalysiert den Abbau des RNA-Prägenoms während der reversen Transkriptasereaktion.

Die Funktion des vom X-ORF kodierten Genproduktes, dem X-Protein, ist bisher noch nicht eindeutig geklärt. Es hat wahrscheinlich regulatorische Aufgaben. 


\subsection{Ziel der Arbeit}

Der abschließende Schritt der Virusmorphogenese des HBV ist die Umhüllung des cytoplasmatisch vorgebildeten Nukleokapsids an der ER-Membran, die die viralen Oberflächenproteine enthält. Es konnte gezeigt werden, dass die Domäne zwischen den Aminosäuren 98 und 124 des großen Hüllproteins für die Umhüllung essentiell ist ${ }^{[59]}$.

Bisher nicht geklärt ist die Frage, ob der zum Cytosol gerichtet Bereich des L-Proteins zwischen Aminosäure 170 und 253 einen direkten Einfluß auf die Virusbildung hat und ob abstandsverändernde Mutationen (Deletionen) in diesem Bereich geduldet werden.

Hierzu sollen in einem Expressionsvektor für das L-Protein die entsprechenden Deletionen im Bereich von Aminosäure 170 bis 253 eingeführt werden. Die so konstruierten Mutanten sollen zunächst in Zellkulturexperimenten exprimiert und nachgewiesen werden. Durch Kotransfektion humaner Hepatomzelllinien mit einem HBV-Genom, das kein L-Protein exprimieren kann, zusammen mit den deletierten L-Konstrukten soll der Phänotyp der Mutationen in Bezug auf Nukleokapsidumhüllung bestimmt werden.

Durch diese phänotypische Charakterisierung der Mutanten soll die Bedeutung der L-Protein-Domäne zwischen Aminosäure 170 und 253 für die Virusbildung aufgeklärt werden. 


\section{Allgemeiner Teil}

\subsection{Mutagenisierung des großen Hüllproteins L}

\subsubsection{Exonukleolytische Verkürzung von Plasmid-DNA mit Bal31}

Um untersuchen zu können, in wie weit der cytosolische Bereich des L-Proteins zwischen den Aminosäuren 174 und 253 Einfluß auf die Virusbildung hat, wurden Plasmide konstruiert, die in dem entsprechenden Bereich Deletionen von 24 bis 121 Aminosäuren Länge aufwiesen. Hierzu wurde der Vektor pSVL (4.1.8), der aufgrund zweier Mutationen der Startcodons für das M- und S-Gen nur das L-Protein exprimiert, zunächst mit dem Restriktionsenzym PstI (nt 21) linearisiert. Es wurden $20 \mu \mathrm{g}$ des Vektors $1 \mathrm{~h}$ bei $37^{\circ} \mathrm{C}$ mit PstI inkubiert und anschließend mit Ethanol gefällt (4.2.2.5). Das Pellet wurde in $20 \mu 1 \mathrm{H}_{2} \mathrm{O}$ aufgenommen, resuspendiert und in Aliquots von je $5 \mu$ l portioniert. Anschließend wurden die Aliquots unterschiedlich lang bei $37^{\circ} \mathrm{C}$ mit der Exonuklease Bal31, die in der Lage ist, doppelsträngige DNA sowohl am 3'- wie auch am 5'-Ende unter Erzeugung von stumpfen Ende („,blunt-ends“) abzubauen, behandelt (4.2.2.10). Es wurden vier verschiedene Reaktionszeiten gewählt, die zwischen 5 und 15 min lagen. Nach Abstoppen der Reaktion mit EGTA (10 mM Endkonzentration) und anschließender Phenol-Chloroform-Extraktion (4.2.2.3) wurden die Reaktionsansätze für 5 min bei $65^{\circ} \mathrm{C}$ inkubiert, um das Enzym zu inaktivieren. Anschließend wurde der Reaktionsansatz erneut mit Phenol/Chloroform extrahiert und mit Ethanol gefällt. Danach wurden zwei unterschiedliche Restriktionsenzyme (EcoRV und SpeI) ausgewählt, um die relativ geringe Anzahl der degradierten Basenpaare und somit die Länge der entstandenen Fragmente auf dem Agarosegel besser abschätzen zu können. Hierzu wurden Aliquots der Reaktionsansätze mit je einem der beiden Enzymen $1 \mathrm{~h}$ inkubiert und anschließend auf ein analytisches Agarosegel aufgetragen (Abb. 2.1). Nachdem sicher gestellt war, dass die Fragmente die entsprechenden Verkürzungen aufwiesen, wurde der restliche Reaktionsansatz, um ein einheitliches 3'-Ende aller verkürzten Fragmente zu erhalten, mit dem Restriktionsenzym SpeI für $1 \mathrm{~h}$ bei $37^{\circ} \mathrm{C}$ inkubiert und direkt auf ein präparatives $1 \%$-iges Agarosegel (4.2.2.8) aufgetragen. Die Banden der so verkürzten Fragmente wiesen Längen von 350 bis 650 Basenpaaren auf. Diese wurden, um sie vom Rest des Vektors zu isolieren, mit einem Skalpell aus dem Gel ausgeschnitten und anschließend mit dem „QIAquick Gel Extraction 
Kit“ der Firma QIAGEN, Hilden, nach dem Protokoll des Herstellers aufgereingt und die DNA mit $50 \mu 1$ TE von der Säule eluiert.

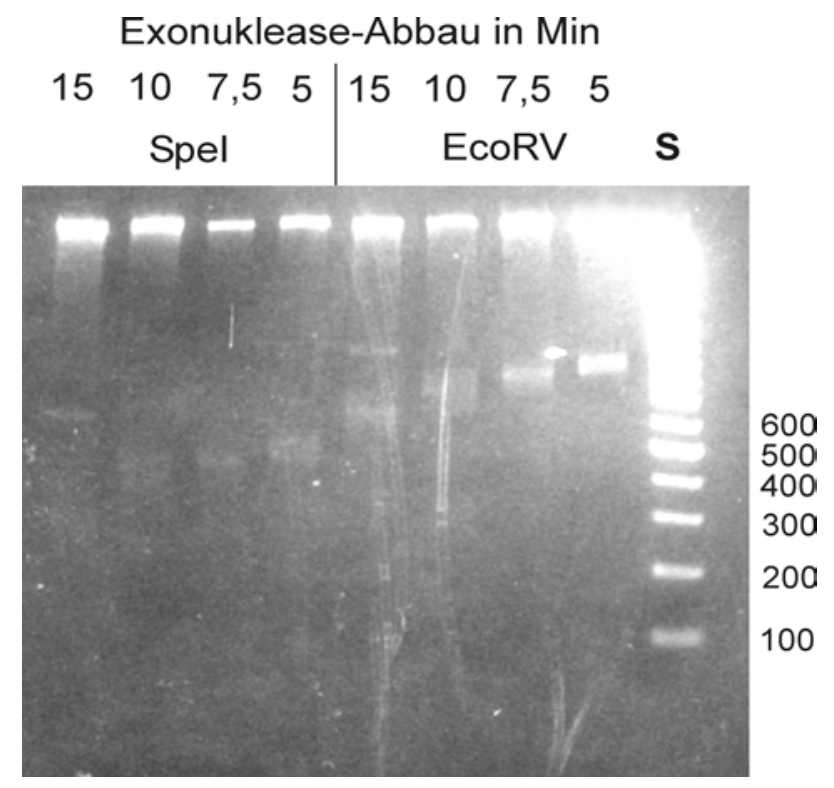

Abb. 2.1: Behandlung linearisierter DNA mit der Exonuklease Bal31

Das Plasmid pSVL wurde mit der Restriktionsendonuklease PstI linearisiert. Nach unterschiedlichen Inkubationszeiten mit Bal31 wurde die Reaktion durch PhenolChloroform-Extraktion abgestoppt, und nach Präzipitation der Reaktionsansätze wurden die erhaltenen Fragmente mit EcoRV oder SpeI für 45 min inkubiert. Ein Aliquot jedes Ansatzes wurde anschließend auf ein analytische Agarosegel aufgetragen um die Länge der entstandenen Fragmente abschätzen zu können. Auf der rechten Spur ist der DNALängenstandard (S) aufgetragen (Gene Ruler ${ }^{\mathrm{TM}} 100 \mathrm{Bp}$ DNA Ladder).

\subsubsection{Modifikation von pSVL}

Um die am 5'-Ende mit Bal31 unterschiedlich verkürzten und am 3'-Ende mit SpeI egalisierten Fragmente in das L-Gen exprimierende Plasmid einfügen zu können, wurden $10 \mu \mathrm{g}$ des Plasmids pSVL zunächst $1 \mathrm{~h}$ bei $37^{\circ} \mathrm{C}$ mit PstI inkubiert. Um das überstehende 5 '-Ende zu entfernen, wurde das Plasmid anschließend eine halbe Stunde mit Mung BeanNuklease bei $30^{\circ} \mathrm{C}$ behandelt (4.2.2.11). Mung Bean-Nuklease ist ein Enzym, das in der Lage ist, überhängende 3 '- und 5'-Enden doppelsträngiger DNA abzubauen und somit stumpfe Enden $\mathrm{zu}$ erzeugen. Nach Phenol-Chloroform-Extraktion (4.2.2.3) und anschließender Ethanolfällung (4.2.2.5) wurde das Plasmid mit SpeI (nt 677) bei $37^{\circ} \mathrm{C}$ für 1h inkubiert. Der Reaktionsansatz wurde vollständig auf ein präparatives $1 \%$-iges Agarosegel aufgetragen und die ca. 5,3 Kb große Vektorbande vom PstI/SpeI-Fragment 
durch Ausschneiden des Gelstücks und anschließender Aufreinigung mit dem „QIAquick Gel Extraction Kit“" der Firma QIAGEN, Hilden nach dem Protokoll des Herstellers isoliert. Die DNA wurde in $50 \mu \mathrm{TE}$ aufgenommen. In den so modifizierten Vektor pSVL konnten nun die zuvor durch Bal31 degradierten Fragmente eingefügt werden.

Hierzu wurden ca. $10 \mathrm{ng}$ des mit PstI/MBN und SpeI vorbehandelten Vektors pSVL mit je $30 \mathrm{ng}$ der aus den 4 Reaktionsansätzen erhaltenen verkürzten Fragmenten $12 \mathrm{~h}$ bei $16^{\circ} \mathrm{C}$ mit T4-DNA-Ligase inkubiert (4.2.2.13).

Nach anschließender Transformation von E. coli-Zellen (4.2.1.3) mit den Ligationsansätzen wurden $3 \mathrm{ml}$ LB-Amp-Kulturen mit zufällig ausgewählten Kolonien angeimpft und die Plasmid-DNA im analytischen Maßstab aufgereinigt (4.2.2.1).

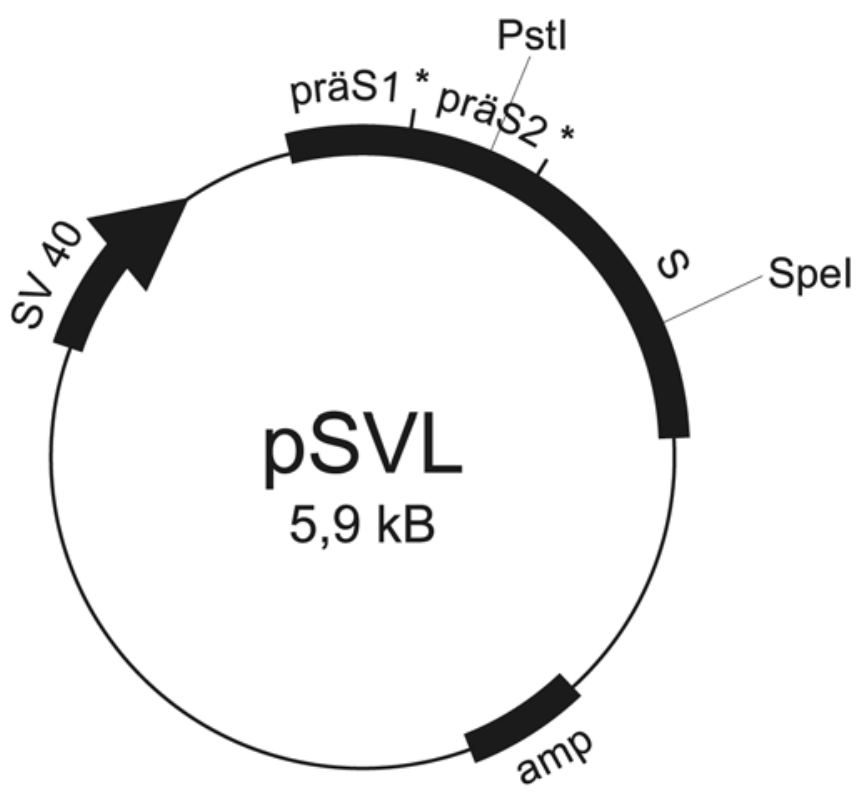

Abb. 2.2: Darstellung des Expressionsvektors pSVL

Der oben dargestellte Vektor wurde mit PstI linearisiert und das überstehende 5'-Enden mit Mung Bean-Nuklease degradiert. Mit SpeI wurde anschließend ein ca. 650 Bp großes Fragment herausgeschnitten. In den so modifizierten Vektor wurden die durch Bal31 verkürzten Fragmente über das stumpfe 3'-Ende und die SpeI Schnittstelle einligiert. Die Sternchen kennzeichnen die Mutationen der Startkodons des M und S-Gens zu ACG. 


\subsubsection{Restriktionsanalyse einer Auswahl von Plasmiden}

Die isolierten Plasmide wurden mit zwei Restriktionsendonukleasen geschnitten, so dass ein Fragment von etwa 1000 Bp Größe entstand, welches durch Mutagenese verkürzt sein sollte. Die geschnittenen Plasmide wurden auf ein 1\%-iges analytisches Agarosegel aufgetragen. Abb. 2.3 zeigt ein Beispiel für eine solche Analyse. Die präparierten Plasmide wurden mit EcoRI (nt 0/3221) und EcoRV (nt 1050) gespalten.

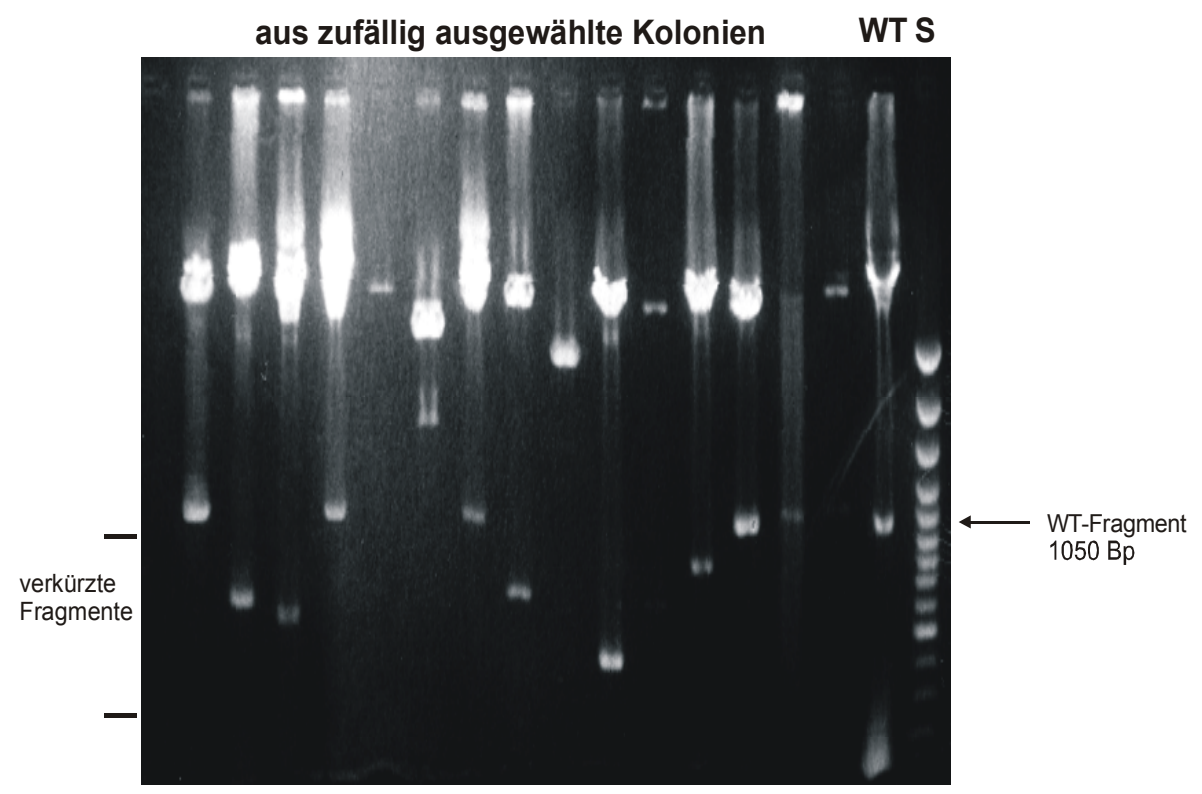

Abb. 2.3: Restriktionsanalyse einer Auswahl der durch die Exonuklease Bal31 veränderten Plasmide

Die Auftrennung der DNA-Fragmente wurde in einem 1\%igen Agarosegel durchgeführt. In der rechten Spur ist der DNA-Srandard aufgetragen (Gene Ruler ${ }^{\mathrm{TM}} 100$ bp DNA Ladder (4.1.7)). Die folgende Spur zeigt ein 1050 Bp großes Fragment von pSVL, das nicht durch exonukleolytischen Abbau mutiert wurde In den weiteren Spuren sind verschiedene mutierte Plasmide aufgetragen. Das urspünglich $1050 \mathrm{Bp}$ große Fragment hat hier durch Deletion eine Länge zwischen etwa 400 und 900 Bp. .

\subsubsection{Sequenzierung einer Auswahl von Mutanten}

Zur genaueren Charakterisierung des exonukleolytischen Abbaus wurde der mutagenisierte Bereich der Plasmide, die nach Agarosegelanalyse ein verkürztes EcoRI/EcoRV-Fragment aufwiesen, sequenziert (4.2.2.16). Durch Einsatz des Oligonukleotids VB\#5 in die Sequenzierreaktion konnte die Art, Größe und Position der Mutation ausgehend von der PstI Schnittstelle auf Nukleotid- und Aminosäureebene bestimmt werden. Durch 
Sequenzierung von ca. 400 Plasmiden wurden 53 unterschiedliche Mutationen identifiziert. Die anderen Plasmide hatten Wildtyp-Sequenzen, wiederholte Mutationen oder einen unterbrochenen Reading Frame. Es wurden außerdem Plasmide erhalten deren Deletionsendpunkt sich entweder vor oder hinter dem zu untersuchenden Bereich zwischen As 170 und As 252 befand. Es zeigte sich, dass der Abbau mit Bal31 nicht gleichmäßig über den gesamten Bereich zwischen Aminosäure 170 und 252 stattfand. Sehr viele Plasmide wurden mit dem Endpunkt an Aminosäure 249 isoliert, während es nicht gelang, Plasmide zu erhalten, bei denen die Endpunkte des exonukleolytischen Abbaus im Bereich zwischen Aminosäure 200 und 245 lag. Mutanten, deren Sequenz eine Verschiebung des Leserasters aufwies, wurden verworfen. Letztendlich wurden elf Plasmide ausgewählt, deren DNA im präparativem Maßstab angereichert wurde (4.2.2.2), um anschließend in Zellkulturexperimente eingesetzt zu werden.

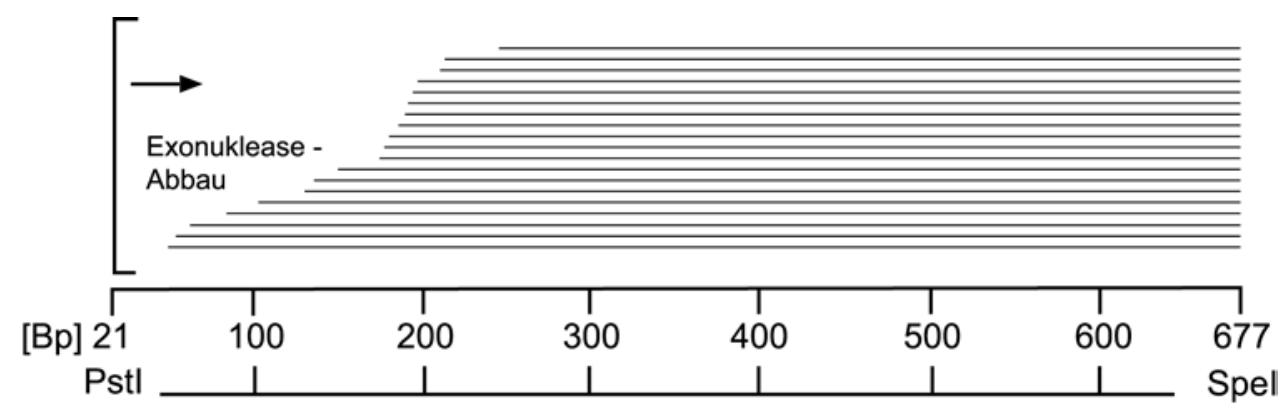

Abb. 2.4: Schematische Darstellung des Exonuklease-Abbaus

Fragmente, die nach Schnitt mit PstI (nt 21), Bal31-Behandlung und Schnitt mit SpeI (nt 677) entstanden waren wurden über ein 1\%-iges Agarosegel isoliert. Die Länge des exonukleolytischen Abbaus ausgehend von der PstI-Schnittstelle wurde durch DNASequenzierung bestimmt. Dadurch entstand ein Eindruck über die Verteilungen der Fragmentlängen.

Der Exonuklease-Abbau ist von PstI ausgehend dargestellt. Die Striche markieren den verbliebenen DNA-Teil vom 3'- bis zum 5'-Ende. 


\subsection{Erste Selektion von L-Protein-Mutanten in Zellkultur}

\subsubsection{Nachweis der Hüllproteinbildung in Zelllysaten}

Im folgenden sollte untersucht werden, wie sich die durch Bal31 in den Expressionsvektor pSVL eingeführten ,in-Phase“-Deletionen, auf die Expression des großen Hüllproteins auswirken. Hierzu wurden COS7-Zellen mit je $2 \mu \mathrm{g}$ des deletierten Plasmids mittels DEAE-Dextran (4.2.3.3) transient transfiziert.

Zur Untersuchung der Expression der Proteine wurden sie radioaktiv markiert. Die radioaktive Markierung erfolgte durch Einbau von ${ }^{35} \mathrm{~S}$-markiertem Cystein/Methionin mit dem Easy Tag Express ${ }^{35}$ S-Protein labeling mix (4.1.13) für 30 min unter $\mathrm{CO}_{2}$-Atmosphäre. Anschließend wurde der Zellkulturüberstand abgesaugt. Die Zellen einer Kulturschale mit $2 \mathrm{~cm}$ Durchmesser wurden $1 \times$ mit PBS gewaschen und nach 5-minütiger Inkubation mit Lysispuffer (4.1.1) abgelöst. Je $1 \mathrm{ml}$ des Zelllysats wurde anschließend mit $1 \mu 1$ anti-HBs (4.1.10), einem polyklonalen Serum aus der Ziege, welches die Hüllproteine des HBV erkennt, $12 \mathrm{~h}$ bei $4^{\circ} \mathrm{C}$ immunpräzipitiert. Im Zellmedium wurden die mutierten LKonstrukte nicht gesucht, da das L-Protein allein nicht von den Zellen sezerniert wird ${ }^{[60]}$.

Nach ihrer Auftrennung über ein SDS-PAGE (4.2.4.6), wurden die radioaktiv markierten Proteine durch ein Autoradiogramm nachgewiesen (4.2.4.8). Es zeigte sich, dass die Mutanten pSVL131-180, pSVL131-185 und pSVL131-187, bei denen sich der Endpunkt des exonukleolytischen Abbaus im Bereich der hydrophoben Domäne von Signal I (As 180 bis As 194) befand, nicht nachweisbar waren. Diese Proteine waren wahrscheinlich instabil und wurden schon während der Markierungsphase abgebaut. Die Mutante pSVL131-193, deren Verkürzung sich ebenfalls auf diese Domäne erstreckte, wies zwei schwache Banden für die glykosylierte und unglykosylierte Form des großen Hüllproteins auf. Für alle übrigen Deletionsmutanten wurden Doppelbanden für die glykosylierte und unglykosylierte Form in unterschiedlicher Intensität erhalten, die im Vergleich zum nicht mutagenisierten Plasmid pSVL, welches als Positivkontrolle mitgeführt wurde, geringere Molekulargewichte hatten. Einige Spuren im Autoradiogramm wiesen zudem eine einzelne Bande mit einem Molekulargewicht von ca.18 kD auf (Spuren 1,2,3,6 und11) Dieses Phänomen wird darauf zurückgeführt, dass das ATG-Kodon an Position 247 ebenfalls als Startkodon fungiert, was zur Expression dieses kleinen Proteins führen könnte (Abb. 2.5). 


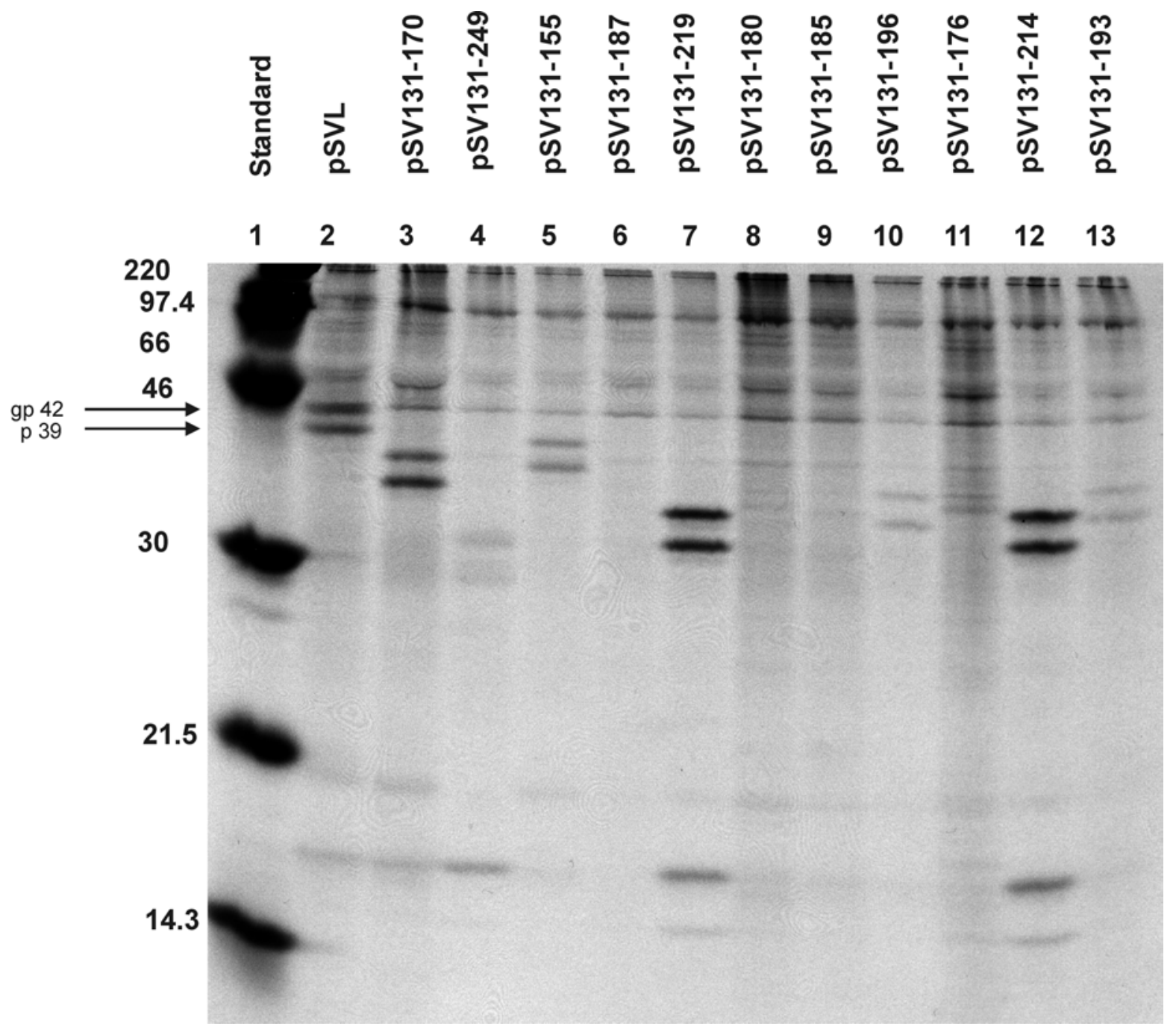

Abb. 2.5: Nachweis ${ }^{35} \mathrm{~S}$-markierter, verkürzter L-Proteine nach Transfektion von COS7-Zellen

Nach einwöchiger Exposition des getrockneten SDS-Gels erfolgte die Entwicklung des Autoradiogramms. Spur 1 zeigt den mit ${ }^{14} \mathrm{C}$-markierten Proteinstandard (4.1.7).Die nachfolgende Spur zeigt das immunpräzipitierte L-Protein das vom nicht mutagenisierten Vektors pSVL exprimiert wurde. In den Spuren 6, 8 und 9 ließ sich das verkürzte Hüllprotein nicht nachweisen. Die Spuren 4, 10,11 und 13 wiesen jeweils nur schwach die Doppelbanden für die glykosylierte und unglykosylierte Form des großen Hüllproteins auf. Die Spuren 3, 5, 7 und 12 wiesen das verkürzte L-Protein mit ähnlich starker Intensität nach wie beim nicht mutagenisierte L-Protein (Spur 2). Die Zahlen links geben die Molekulargewichte der Proteine in $\mathrm{kDa}$ an. 


\subsubsection{Cotransfektion von COS7-Zellen mit pSVBX24H}

Zum Nachweis der Sekretion subviraler $20 \mathrm{~nm}$ Partikel in das Zellmedium wurden die LKonstrukte, deren Expression im Lysat nachweisbar war, mit dem Plasmid pSVBX24H (4.1.8) cotransfiziert. Die Effektivität der Transfektion konnte durch Bestimmung des HBsAg-Gehalts im Zellkulturüberstand mit einem ELISA überprüft werden (4.2.3.5).

Es wurden zunächst Transfektionsversuche gemacht, in denen die deletierten Plasmide zusammen mit pSVBX24H in unterschiedlichen Verhältnissen eingesetzt wurden. Es zeigte sich, dass der Nachweis der exprimierten L-Proteine am besten gelang, wenn die deletierten Plasmide mit pSVBX24H im Mengen-Verhältnis 5:1 cotransfiziert wurden. Es wurden daher 2,5 $\mu \mathrm{g}$ jeder Mutante mit 0,5 $\mu \mathrm{g}$ pSVBX24H auf die Zellen gegeben. Nach zwei Tagen wurden die Zellen mit ${ }^{35} \mathrm{~S}$-markiertem Cystein/Methionin radioaktiv markiert und nach einem weiteren Tag wurde sowohl das Zellmedium wie auch das Lysat geerntet und mit anti-HBs immunpräzipitiert (4.2.4.3). Der Nachweis der im Zellmedium und Zelllysat exprimierten Hüllproteine erfolgte mittels SDS-PAGE (4.2.4.6).Das Autoradiogramm wies erwartungsgemäß für alle Mutanten die entsprechend verkürzten Doppelbanden für das große Hüllprotein im Lysat auf, neben Doppelbanden von 24 und 27 kD für das S-Protein. Im Zellmedium hingegen konnten das L-Protein nur von den Mutanten pSVL131-214 und pSVL31-219 nachgewiesen werden (Abb. 2.6). Der Deletionsendpunkt dieser beiden Mutanten lag jeweils hinter der transmembranen Domäne der Signalsequenz I. 


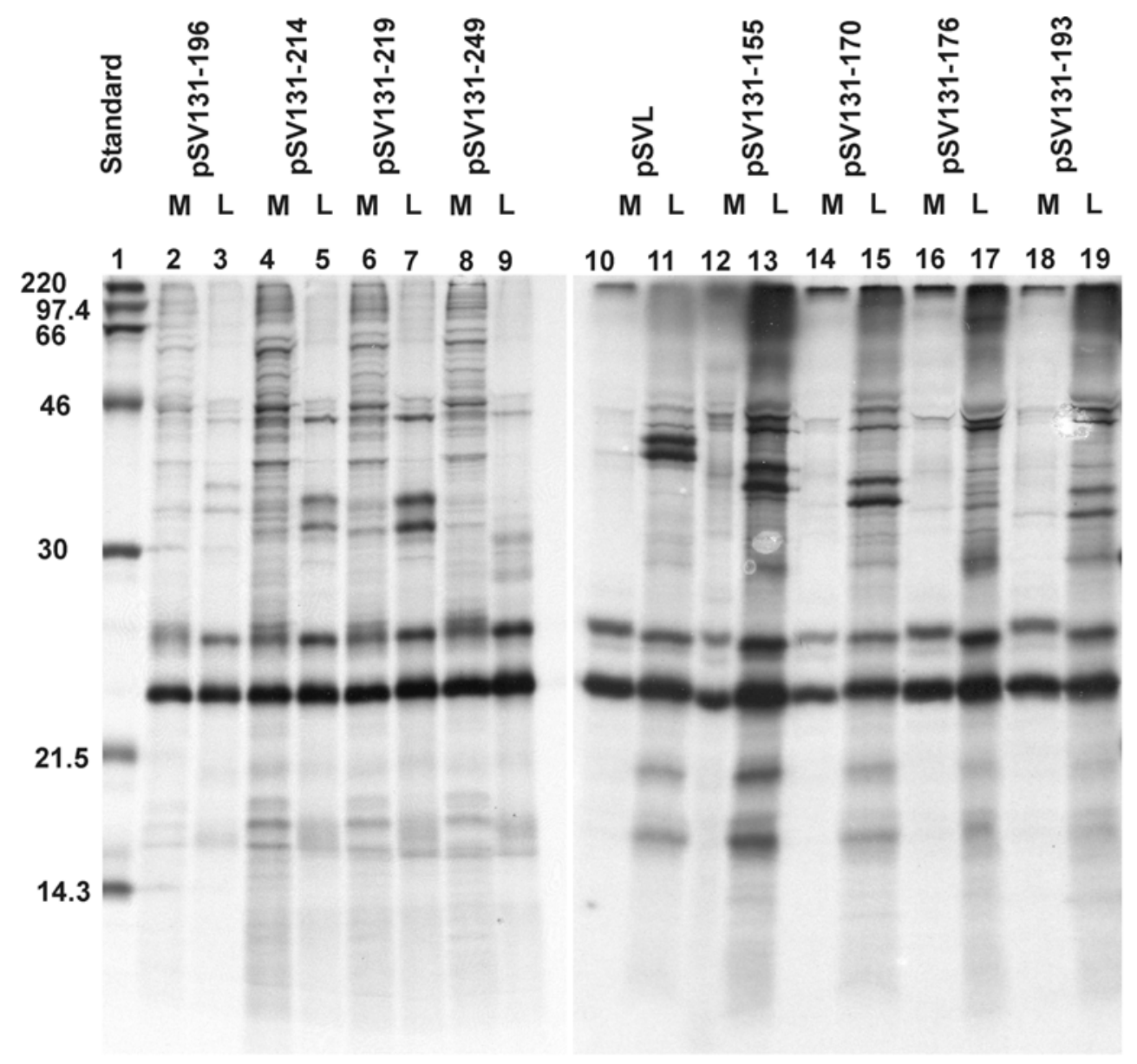

Abb. 2.6: Nachweis der Hüllproteinexpression nach Cotransfektion von COS7-Zellen

COS7-Zellen wurden transient mit den deletierten Plasmiden und dem Expressionsplasmid pSVBX24H cotransfiziert. Nach radioaktiver Markierung der Proteine und Auftrennung in einem Gel erfolgte die Exposition des Gels für eine Woche bei $-70^{\circ} \mathrm{C}$. In Spur 1 ist der ${ }^{14} \mathrm{C}$-markierte Proteinstandard aufgetragen. In den Spuren 2, $4,6,8,11,13,15,17$ und 19 sind die aus dem Zellüberstand immunpräzipitierten Hüllproteine aufgetragen. Die Spuren 3, 5, 7, 9, 10, 12, 14, 16 und 18 zeigen die entsprechenden Banden für die Proteine aus den Lysaten. Die Zahlen am linken Rand der Abbildung geben die Molekulargewichte der Proteine des Standards wieder.

\subsection{Erweiterte Mutagenisierung des L-Proteins}

\subsubsection{Einführung von Deletionen mittels PCR}

Um den Bereich zwischen Aminosäure 200 und Aminosäure 250 näher charakterisieren zu können, in dem es mit der Exonuklease Bal31 nicht gelungen war, Deletionen zu erzeugen und um auszuschließen, durch zufälligen exonukleolytischen Abbau weitere Mutanten zu 
erhalten, deren Leseraster eine Verschiebung aufwies (im Mittel zwei von drei Mutanten), wurden daher Fragmente mit bekanntem 3'- und 5'-Ende mittels PCR aus dem Expressionsplasmid pSVL amplifiziert (4.2.2.14) um sie anschließend in den zuvor mit PstI/MBN und SpeI behandelten Vektor (2.2) einzufügen. Die sense-Oligonukleotide wurden hierfür so gewählt, dass das 5'-Ende eine ,in Phase“- Mutation nach der Religation (2.1.2) lieferte, und das außerdem unter Einführung einer Punktmutation an der Fusionsstelle von PCR-Fragment und pSVL-Vektor ein Kodon für die Aminosäure Leucin entstand, um die Polarität der Aminosäurereste nicht zu verändern. Das antisenseOligonukleotid war für alle Fragmente einheitlich (\#244) und erzeugte ein 3'-Ende, welches ca. 100Bp hinter der SpeI-Schnittstelle lag (Tab. 2.1).

\begin{tabular}{|l|l|}
\hline L-Konstrukt & sense-Oligonukleotid \\
\hline pSV131-205 & $\# 238$ \\
\hline pSV131-210 & $\# 239$ \\
\hline pSV131-225 & $\# 240$ \\
\hline pSV131-230 & $\# 241$ \\
\hline pSV131-237 & $\# 242$ \\
\hline pSV131-252 & $\# 243$ \\
\hline
\end{tabular}

Tab. 2.1: Erzeugung von L-Konstrukten mit entsprechend ausgewählten Primern für das 5'-Ende.

Zur Amplifikation der Fragmente wurde Pfu-Polymerase eingesetzt, die im Gegensatz zur gebräuchlicheren Taq-Polymerase stumpfe Enden (,,blunt-ends“) bei der Elongation der Template-DNA erzeugt. Für die PCR wurde folgendes Temperaturprogramm gewählt (Tab.2.2)

\begin{tabular}{|l|l|}
\hline $2 \min , 95^{\circ} \mathrm{C}$ & \\
\hline $30 \mathrm{sek}, 95^{\circ} \mathrm{C}$ & 30 Zyklen \\
$30 \mathrm{sek}, 42^{\circ} \mathrm{C}$ & \\
$45 \mathrm{sek}, 72^{\circ} \mathrm{C}$ & \\
\hline $10 \min 72^{\circ} \mathrm{C}$ & \\
\hline
\end{tabular}

Tab. 2.2: Temperaturprogramm für die PCR. 
Zur Überprüfung der PCR wurde ein Aliquot jedes Reaktionsansatzes auf ein analytisches Agarosegel aufgetragen. Die Fragmentlängen betrugen zwischen 530 und 390 Basenpaaren (Abb. 2.7 ).

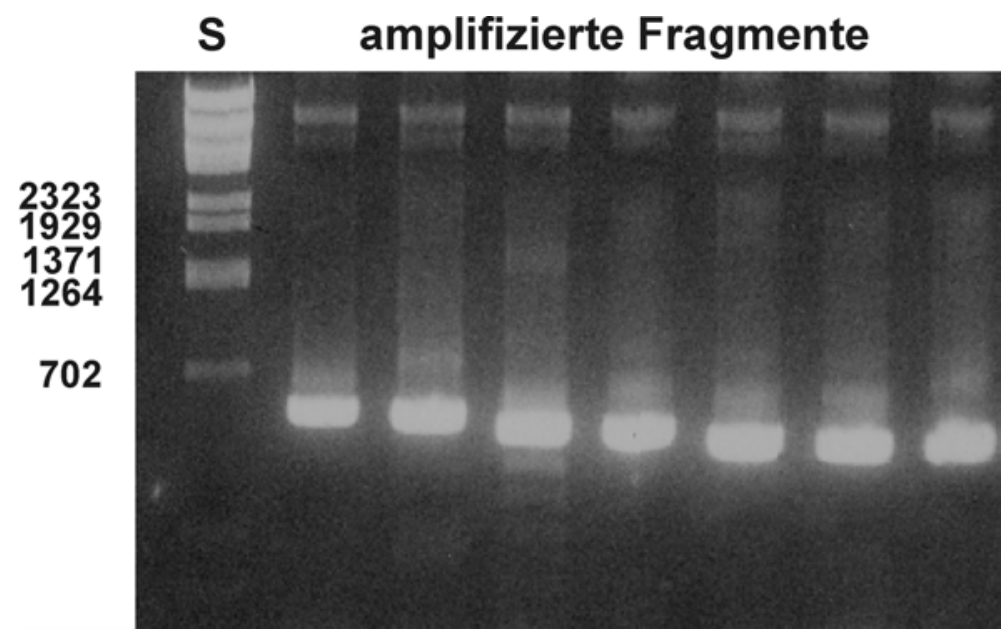

Abb. 2.7: Amplifikation verschieden großer Fragmente aus pSVL mittels PCR

Die Auftrennung der Fragmente erfolgte in einem 1\%igen Agarosegel. In der linken Spur ist der DNA-Standard (S) aufgetragen ( $\lambda$-DNA, BstEII-gespalten (4.1.7)). Die Zahlen geben die Länge der DNA-Fragmente an. In den folgenden Spuren wurden die Fragmente in der Reihenfolge ihrer Größe aufgetragen. Ihre Längen variierten zwischen 530 und 390 Bp. Die so erhaltenen Fragmente wurden mit SpeI geschnitten, über Gelelektrophorese aufgereinigt und in den modifizierten Vektor pSVL (2.1.2) einligiert.

Zur nachfolgenden Reaktion mit dem Restriktionsenzym SpeI mußte das DNA-Fragment von eventuell störenden Reaktionskomponenten der PCR getrennt werden. Hierzu wurde es mit dem „QIAquick PCR Purification Kit“ der Firma QIAGEN, Hilden nach dem Protokoll des Herstellers gereinigt (4.2.2.15).

Der anschließende Restriktionsverdau mit SpeI lieferte Fragmente mit einem stumpfen 5'Ende und einem überstehenden 3'-Ende. Der gesamte Reaktionsansatz wurde auf ein präparatives Agarosegel aufgetragen und die Fragmente durch Ausschneiden der Gelstücke von der 100 Bp-Bande isoliert. Nach Aufreinigung mit dem „QIAquick Gel Extraction Kit““ der Firma QIAGEN, Hilden wurden die Fragmente in den modifizierten pSVL-Vektor (2.1.2) eingefügt. Hierzu wurden ca. $10 \mathrm{ng}$ pSVL mit je $30 \mathrm{ng}$ von jedem Fragment $12 \mathrm{~h}$ mit T4-DNA-Ligase bei $16^{\circ} \mathrm{C}$ inkubiert (4.2.2.13) und anschließend zur Transformation kompetenter E. coli-Zellen benutzt (4.2.1.3). Es wurden $3 \mathrm{ml}$ TB-Amp-Kulturen mit zufällig ausgewählten Kolonien angeimpft und ihre DNA in analytischem Maßstab aufgereinigt. Danach wurden je $3 \mu \mathrm{l}$ der Präparation mit EcoRI und EcoRV für $1 \mathrm{~h}$ inkubiert und zur Kontrolle auf ein analytische Agarosegel aufgetragen. Plasmide, deren 
EcoRI/EcoRV-Fragment kleiner als $1000 \mathrm{Bp}$ war, wurden danach sequenziert (4.2.2.16). Die Sequenz wurde, da die verwendeten Mutations-Primer manchmal Fehler enthielten, auf die eingeführte Punktmutation hin überprüft und darauf, dass sie der erwarteten Sequenz entsprach.

Nachdem sicher gestellt war, dass es sich um die erwartete Sequenz handelte, wurden

$40 \mu \mathrm{l}$ der entsprechenden Vorkultur in eine $30 \mathrm{ml}$ TB-Amp-Kultur überimpft und ihre DNA in präparativem Maßstab angereichert (4.2.2.2). Auf diese Weise wurden sieben weitere Deletionsmutanten konstruiert.

\subsubsection{Phänotypische Charakterisierung neu erzeugter L-Konstrukte in COS7-Zellen}

Wie zuvor mit den durch exonukleolytischen Abbau deletierten Plasmiden wurden COS7Zellen mit durch PCR konstruierten Deletionsmutanten transient transfiziert.

Wie bereits in (2.2.1) beschrieben wurde die Expression der verkürzten großen Hüllproteine im Zelllysat nach radioaktiver Markierung, Immunpräzipitation mit je $1 \mu \mathrm{l}$ anti-HBs und anschließender SDS-PAGE mit einem Autoradiogramm nachgewiesen. Der deletierte Bereich erstreckte sich auf die Aminosäuren 205 bis 252 in Abständen von ca. 5 bis 10 Aminosäuren.

Das Autoradiogramm wies, wie erwartet für die mitgeführte Positivkontrolle eine Doppelbande bei 42 und $39 \mathrm{kD}$ auf, was der glykosylierten und unglykosylierten Form des großen Hüllproteins entspricht. Entsprechend ihrer Verkürzungen zeigte das Autoradiogramm für sechs der sieben Mutanten ebenfalls Doppelbanden mit niedrigerem Molekulargewicht. Die Mutante pSVL131-210 wies keine Banden auf dem Autoradiogramm auf, so dass eine Verkürzung an dieser Stelle die Expression des LProteins offensichtlich verhinderte (Abb.2.8). 


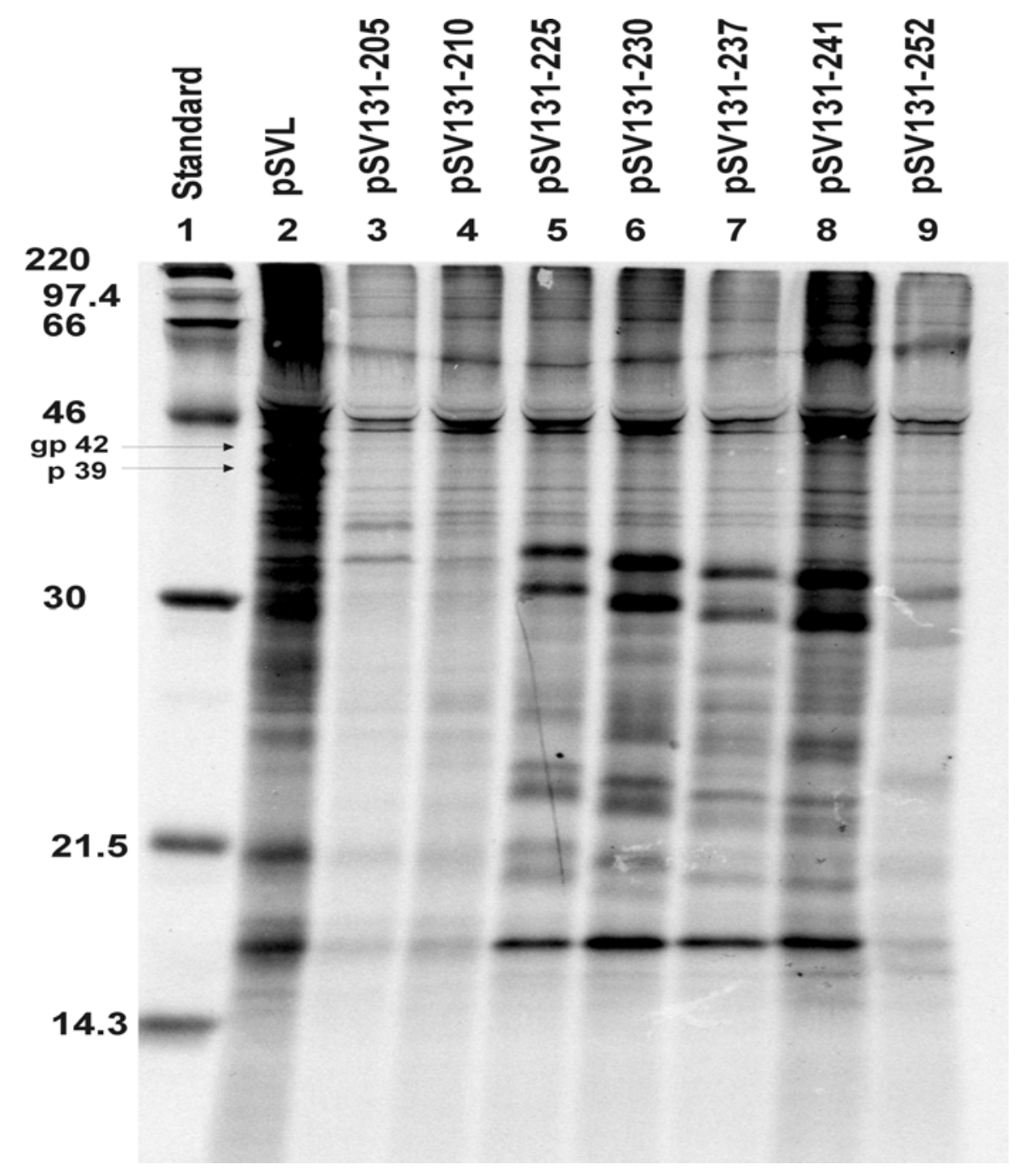

Abb. 2.8: Nachweis der durch PCR verkürzten L-Proteine nach Transfektion von COS7-Zellen

Nach dreitägiger Exposition des Gels erfolgte die die Entwicklung des Autoradiogramms. Spur 1 zeigt den mit ${ }^{14} \mathrm{C}$ radioaktiv markierten Standard. Die Zahlen links geben die Molekulargewichte der Proteine des Standards wieder. Spur 2 weist das nicht deletierte L-Protein von pSVL mit einer Doppelbande bei 42 und $39 \mathrm{kD}$ auf entsprechend der glykosylierten und unglykosylierten Form des großen Hüllproteins. Die Spuren 3 und 5-7 zeigen Doppelbanden bei niedrigeren Molekulargewichten entsprechend der Verkürzung der L-Proteine. In Spur 4 konnte das deletierte große Hüllprotein der Mutante pSV131210 nicht nachgewiesen werden.

\subsection{2 Überprüfung der Sezernierung der deletierten L-Konstrukte}

Um die Sezernierung der neu konstruierten Deletionsmutanten ins Zellmedium zu überprüfen, wurden COS7-Zellen mit den bei der Expression im Zelllysat positiven LKonstrukten und dem S-exprimierende Plasmid pSVBX24H im Mengen-Verhältnis 5:1 cotransfiziert. Nach zwei Tagen wurden die Zellen mit ${ }^{35} \mathrm{~S}$-Cystein/Methionin radioaktiv markiert und nach einem weiteren Tag wurden sowohl das Lysat wie auch das Medium mit 
anti-HBs immunpräzipitiert (4.2.4.3).Nach Auftrennung der Proteine auf einem SDSPolyacrylamidgel wurden diese auf einem Autoradiogramm nachgewiesen (4.2.4.8).

Abb. 2.9 zeigt, dass alle Mutanten im Zelllysat Doppelbanden aufwiesen. Die Mutanten pSVL131-205, pSVL131-225 und pSVL131-230 aus dem Zellmedium wiesen ebenfalls Doppelbanden auf, was die Fähigkeit der so verkürzten L-Konstrukte anzeigte, von den Zellen in das Medium sezerniert werden zu können. Die übrigen deletierten Plasmide waren hierzu nicht in der Lage.

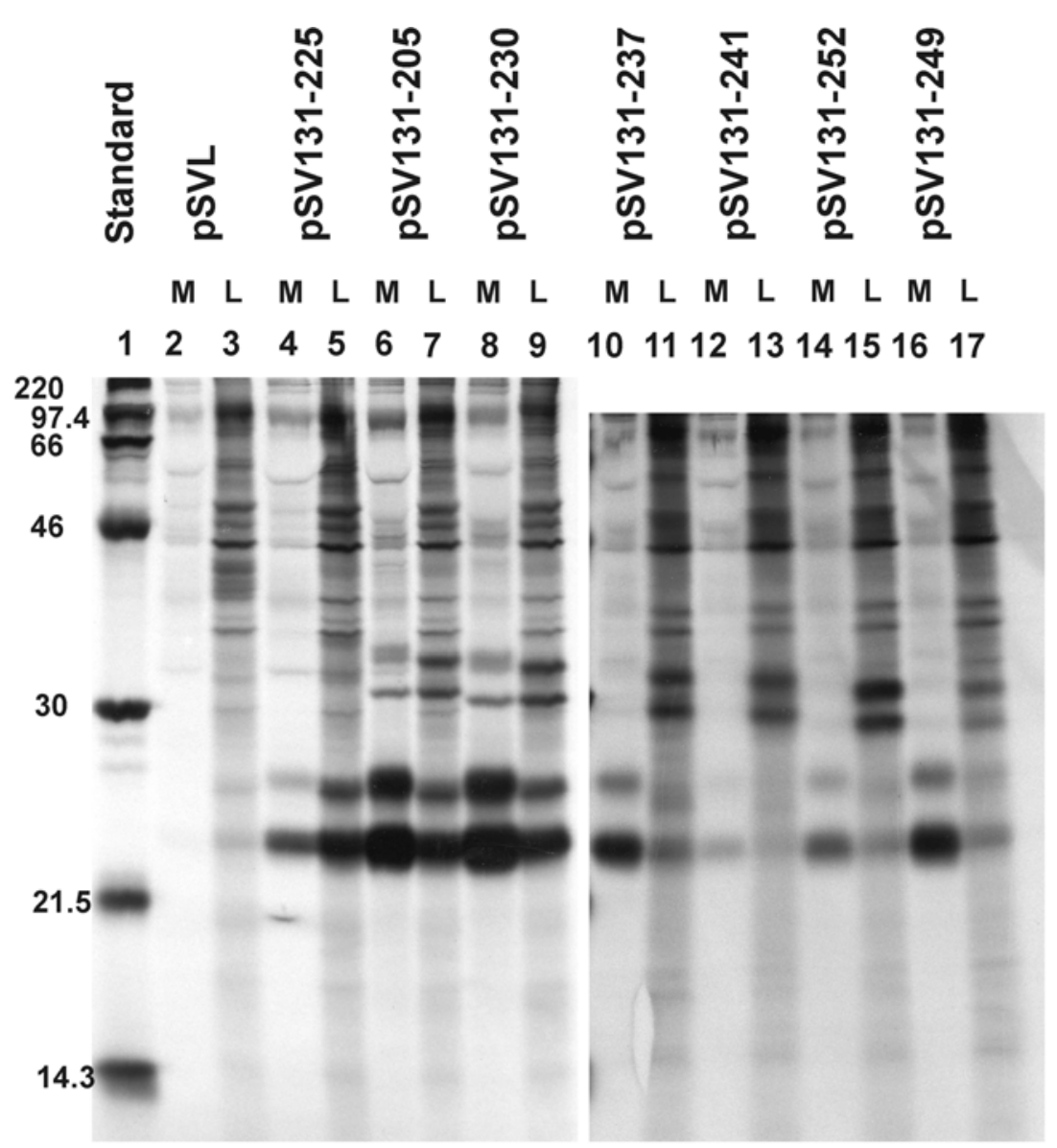

Abb. 2.9: Nachweis der aus Zellmedium und -lysat immunpräzipitierten deletierten L-Proteine nach Cotransfektion von COS7-Zellen

Die Entwicklung des Autoradiogramms erfolgte nach zweiwöchiger Exposition. In Spur 1 wurde der ${ }^{14} \mathrm{C}$-markierte Standard aufgetragen. Die ungeraden Spuren (3, 5, 7 usw) wiesen sowohl für das nicht verkürzte L-Protein von pSVL (Spur 3) wie auch für alle deletierten L-Proteine Doppelbanden im Lysat auf. Im Zellmedium konnten nur für die Mutanten pSV131-205, pSV131-225 und pSV131-230 Doppelbanden detektiert werden. Die übrigen verkürzten L-Proteine waren nicht in der Lage, von den Zellen sezerniert zu werden. 


\subsection{Cotransfektion von HuH7-Zellen}

Aus den vorangegangen Versuchen sind L-Protein-Mutanten hervorgegangen, die entweder gar nicht exprimiert werden konnten oder bei deren Expression durch radioaktive metabolische Markierung der Zelllysate nachgewiesen werden konnte. Nur 5 von 18 der in COS7-Zellen getesteten deletierten Plasmide waren in der Lage, das verkürzte große Hüllprotein außerdem aus den Zellen in das Medium zu sekretieren. Diese 5 Mutanten waren also in der Lage in subvirale Partikel eingebaut zu werden. Sie erfüllten damit eine Voraussetzung, um nun im weiteren ihre Fähigkeit zur Umhüllung des HBVNukleokapsids testen zu können.

Um zu überprüfen, wie sich die durch Deletion verkürzten L-Proteine auf die Virusbildung auswirkte, wurden HuH7-Zellen mit diesen 5 L-Konstrukten zusammen mit dem Expressionsplasmid pSVHBV1.5 L' cotransfiziert. Das Plasmid pSVHBV1.5L- ist in der Lage, bis auf das große Hüllprotein alle Virusproteine zu exprimieren.

HuH7-Zellen, die aus einem humanen Hepatom stammen, sind im Gegensatz zu COS7Zellen in der Lage, komplette Virionen zu bilden Damit die Virusreifung stattfinden kann, müssen außer dem X-Gen und $\mathrm{HBeAg}$ alle anderen Viruskomponenten in den Zellen gebildet werden. Die HuH7-Zellen wurden hierzu mit je $1 \mu \mathrm{g}$ des Deletionsplasmids und $1 \mu \mathrm{g}$ pSVHBV1.5 $\mathrm{L}^{-}$mittels der Kalziumphosphatmethode (4.2.3.4) cotransfiziert. Nach vier Tagen wurden die Zelllysate und die Zellmedien geerntet. Es wurde je $1 \mathrm{ml}$ des Zelllysats mit $1 \mu \mathrm{l}$ anti-HBc sowie $1 \mathrm{ml}$ des Mediums mit $1 \mu 1$ anti-HBs immunpräzipitiert.

\subsubsection{Endogene Polymerasereaktion}

Die so erhaltenen viralen Partikel wurden einer endogenen Polymerasereaktion (4.2.4.9) unterzogen. Dieses Testsystem erlaubt es, die Aktivität der viralen Polymerase zu untersuchen und somit indirekt einen Nachweis auf das Vorhandensein von intakten Nukleokapsiden im Zellysat und kompletten Virionen im Zellmedium zu führen.

Die 3 x mit PBS gewaschenen Immunpräzipitate wurden $12 \mathrm{~h}$ mit einer gepufferten Lösung, die unter anderem die Nukleotide dATP, dGTP, dTTP und das radioaktiv markierte Nukleotid $\alpha^{32}$ PdCTP enthielt (4.1.1), inkubiert. Nach Aufreinigung der Proben durch Phenol-Chloroform-Extraktion und anschließender zweimaliger Fällung der DNA mit Ammoniumacetat/Ethanol-Lösung (10 $\mathrm{M} \mathrm{NH}_{4} \mathrm{Ac} / \mathrm{EtOH}$ 1:10), wurden die Sedimente nach 
15-minütiger Zentrifugation getrocknet und in TE-Puffer resuspendiert. Mit Probenauftragspuffer versehen wurden sie dann getrennt nach Zellmedium- und -lysat auf zwei separaten Agarosegelen einer Elektrophorese unterzogen. Die mit $\alpha^{32} \mathrm{PdCTP}$ radioaktiv markierte DNA wurde durch Autoradiographie (4.2.4.8) detektiert.

Es wurden für alle in das Experiment eingesetzten Mutanten im Lysat Signale erhalten, was auf das Vorhandensein intakter Nukleokapside schließen ließ (Abb.2.10.a).

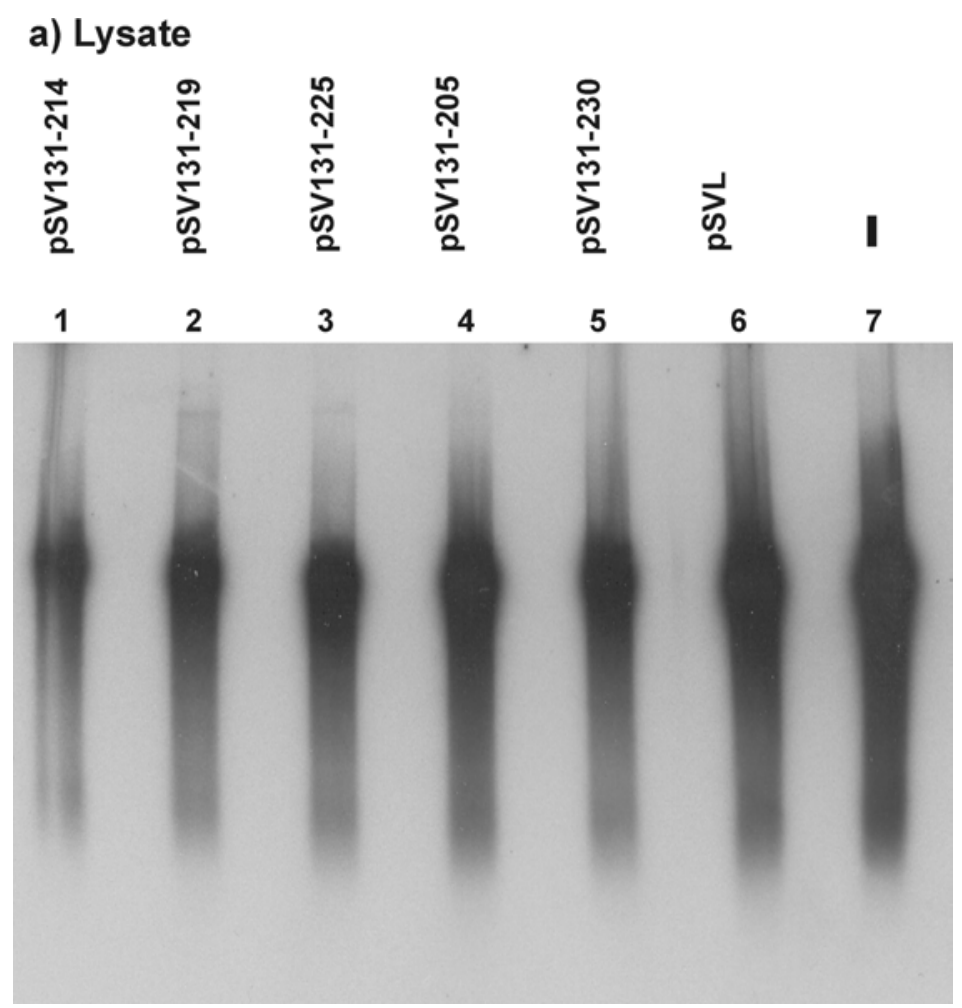

Abb. 2.10.a: Endogene Polymerasereaktion nach Cotransfektion von HuH7-Zellen

Nach eintägiger Exposition erfolgte die Entwicklung der Autoradiogramme.

In Abb. 2.10.a konnten für alle L-Konstrukte, die mit pSVHBV1.5L cotransfiziert wurden, intakte Nukleokapside aus den mit antiHBc immunpräzipitierten Zelllysaten nachgewiesen werden. Spur 6 zeigt das Signal für das nicht deletierte L-Protein von pSVL als mitgeführte Positivkontrolle. In Spur 7 wurde das anti-HBc Präzipitat nach Transfektion von pSVHBV1.5L`allein nachgewiesen.

Ebenso konnte für alle untersuchten Mutanten Virus im Zellkulturüberstand nachgewiesen werden (Abb. 2.10.b). Die Signale waren jedoch im Vergleich zur mitgeführten Positivkontrolle, dem pSVL, wesentlich schwächer. Das schwächste Signal wurde für die Mutante pSV131-230 erhalten. Es wies nur ca. 20\% der Intensität des Signals von pSVL auf (Abb. 2.10.b). Im folgenden wurde überprüft, ob es sich bei diesem Signal tatsächlich 
um ein von Virionen produziertes Signal handelte oder ob es durch eventuell vorhandene Verunreinigungen verursacht worden war.

\section{b) Zellkulturüberstände}

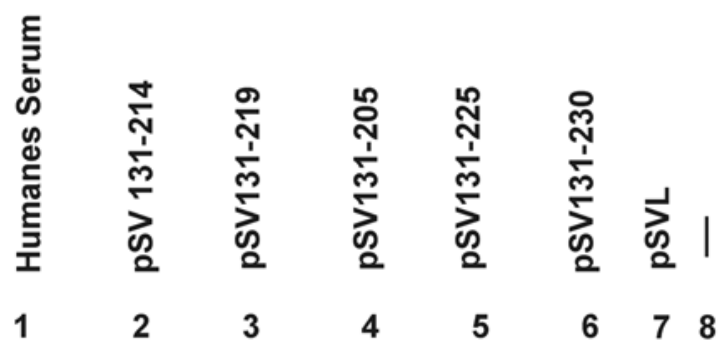

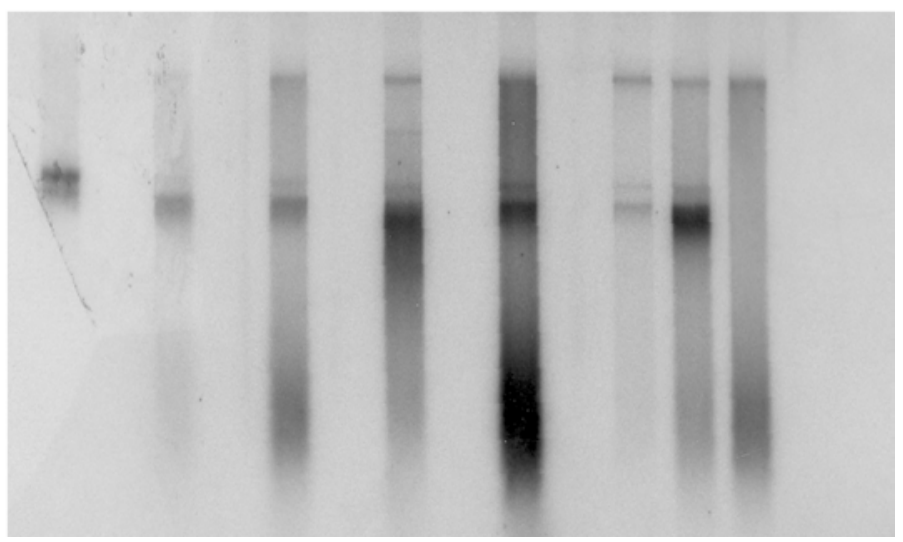

Abb. 2.10.b Endogene Polymerasereaktion nach Cotransfektion von HuH7-Zellen

In Abb. 2.10.b konnten für alle L-Mutanten komplette Virionen nachgewiesen werden. Spur 7 zeigt das Signal des nicht deletierten L-Proteins von pSVL. Die Intensitäten der Signale für die mit pSVHBV1.5L cotransfizierten Mutanten waren erheblich schwächer. Die Signalintensität von Spur 6 betrug nur etwa 20\% der mitgeführten Positivkontrolle (Spur 7). In Spur 8 wurde die gebildete virale DNA nach Transfektion von pSVHBV1.5L' allein aufgetragen. Es wurde erwartungsgemäß kein Signal erhalten.

\subsection{CsCl-Dichtegradientenzentrifugation}

Um Nachweisen zu können, dass die Mutante pSV131-230 tatsächlich in der Lage war, komplette Virionen in das Zellmedium zu sekretieren, wurden HuH7-Zellen in einer $10 \mathrm{~cm}$ Kulturschale mit je $5 \mu \mathrm{g}$ des deletierten Plasmids und $5 \mu \mathrm{g}$ pSVHBV1.5L $\mathrm{L}^{-}$kotransfiziert. Um später eine Quantifizierung der erhaltenen Menge an Virionen vornehmen zu können, wurde eine weitere $10 \mathrm{~cm}$ Kulturschale mit HuH7-Zellen mit der gleichen Mengen des Plasmids pSVL und pSVHBV1.5L' cotransfiziert. Desweiteren wurde eine andere $10 \mathrm{~cm}$ Kulturschale mit $10 \mu \mathrm{g}$ pSVHBV1.5L transfiziert, die als Negativkontrolle dienen sollte. 
Nach vier Tagen wurde das Medium zur Abtrennung nackter Core-Partikel einer CsClDichtegradientenzentrifugation unterzogen (4.2.4.10). Anschließend wurde der Gradient fraktioniert und die Dichte der einzelnen Fraktionen bestimmt (4.2.4.11).Die Dichte der Fraktionen, die nackte Core-Partikel enthalten liegt bei $1,35 \mathrm{~g} / \mathrm{ml}$. Die Virionen enthaltenden Fraktionen mit einer Dichte von $1,23 \mathrm{~g} / \mathrm{ml}^{[59]}$ wurden isoliert und zur Entfernung von $\mathrm{CsCl} 3 \mathrm{~h}$ gegen PBS dialysiert (4.2.4.12) In Anwesenheit des Detergenz NP40, das die Hülle der Virionen zerstört, wurden die Kapside mit anti-HBc, einem polyklonalem Serum aus dem Kaninchen, dass $\mathrm{HBcAg}$ erkennt, immunpräzipitiert (4.2.4.3).Die Immunpräzipitation wurde über Nacht bei $4^{\circ} \mathrm{C}$ durchgeführt. Der Nachweis auf Virionen erfolgte mittels endogener Polymerasereaktion (4.2.4.9). Hierzu wurden die Präzipitate $3 \times$ mit PBS gewaschen und $12 \mathrm{~h}$ mit einer gepufferten Lösung mit den vorhandenen Nukleotiden (dGTP, dATP, dTTP und $\alpha^{32} \mathrm{PdCTP}$ ) bei $37^{\circ} \mathrm{C}$ inkubiert. Nach anschließender Inkubation der Proben mit Proteinase K-Puffer (4.1.1) für 30 min bei $37^{\circ} \mathrm{C}$ wurde die virale radioaktiv markierte DNA mit Phenol-Chloroform-Extraktion und zweimaliger $\mathrm{NH}_{4}$-Acetat/Ethanol-Präzipitation gereinigt und auf ein 1\%-iges Agarosegel aufgetragen. Das Autoradiogramm, in Abb. 2.11 dargestellt, weist erwartungsgemäß kein Signal für das Plasmid pSVHBV1.5L' auf. Im Gegensatz dazu erhielt man für die Mutante pSV131-230 ein Signal, dessen Intensität im Vergleich zur mitgeführten Positivkontrolle von pSVL nur ca. $1 \%$ betrug. Dies zeigte, dass die Virionenbildung zwar möglich war, aber offensichtlich durch die große Verkürzung des L-Proteins stark eingeschränkt zu sein schien. 


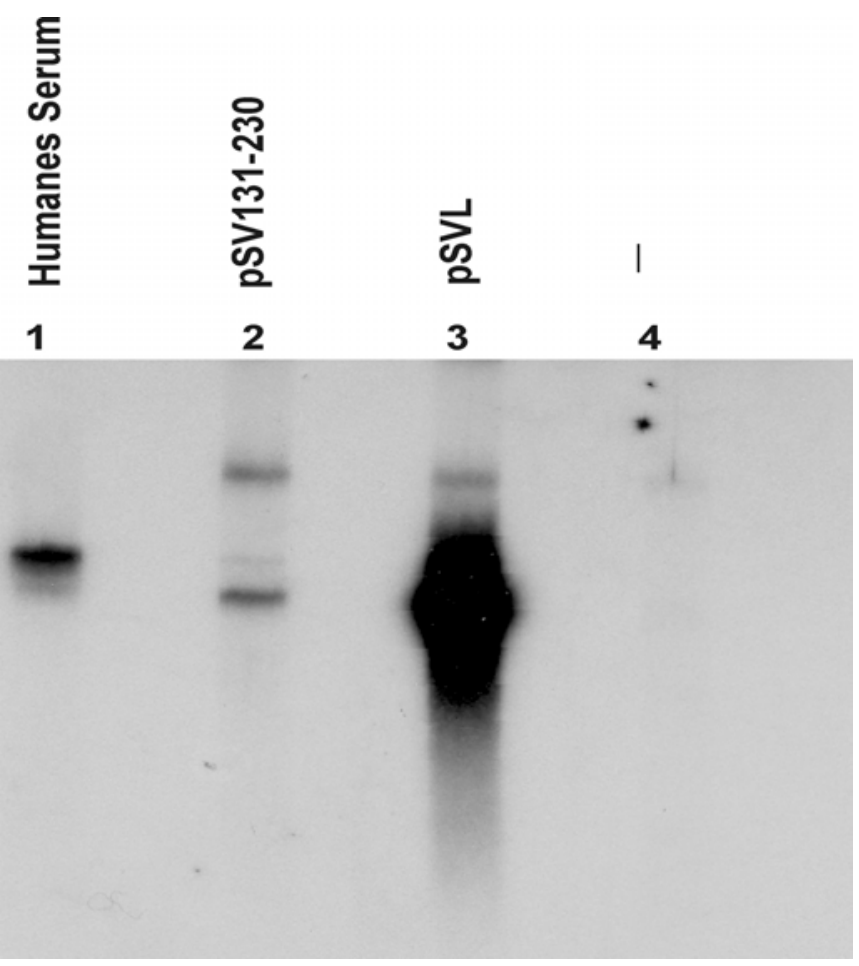

Abb. 2.11: Nachweis von Virionen nach Transfektion von HuH7-Zellen durch CsClDichtegradientenzentrifugation und endogene Polymerasereaktion

Die Entwicklung des Autoradiogramms erfolgte nach 4-stündiger Exposition bei $-70^{\circ} \mathrm{C}$. Spur 1 zeigte das Signal der mitgeführte Positivkontrolle aus einem humanen Serum. Spur 3 weist ein sehr starkes Signal für die mit anti-HBc immunpräzipitierte CsClGradient-Fraktion der Dichte $1,23 \mathrm{~g} / \mathrm{ml}$ in Anwesenheit eines milden Detergenz auf. Für das deletierte L-Konstrukt in Spur 2 wurde ebenfalls ein Signal erhalten, welches im Vergleich zu dem mit pSVHBV1.5L $\mathrm{L}^{-}$cotransfizierten nicht deletierten L-Protein eine Intensität von nur etwa $1 \%$ aufwies.

\subsection{Zusammenfassung der bisherigen Daten}

Das HBV L-Protein wurde im Bereich der beiden transmembranen Signalsequenzen um bis zu 121 AS verkürzt. Die mittels der Exonuklease Bal31 und der PCR eingeführten Deletionen wurden durch Sequenzierung zunächst genotypisch charakterisiert. Die daraufhin erhaltenen deletierten Plasmide wurden anschließend auf ihre Fähigkeit der Hüllproteinexpression in Zelllysaten und Zellkulturüberständen von COS7-Zellen getestet. Deletierte L-Konstrukte, deren Hüllproteinexpression im Zellkulturüberstand nach radioaktiver metabolischer Markierung nachgewiesen werden konnte, wurden durch Cotransfektionsversuche in HuH7-Zellen auf ihre Fähigkeit überprüft, das Nukleokapsid umhüllen zu können und komplette Virionen aus den Zellen zu sekretieren. Tabelle 2.3 liefert eine Übersicht über die erhaltenen Ergebnisse. 


\begin{tabular}{|l|c|c|c|c|}
\hline Bezeichnung & Anzahl deletierter AS & \multicolumn{2}{|c|}{ L-Proteinbildung } & Virionenbildung \\
& \multicolumn{2}{|c|}{ Lysat } & Medium & \\
\hline pSV131-155 & 24 & + & - & n.d. \\
\hline pSV131-170 & 39 & + & - & n.d. \\
\hline pSV131-176 & 45 & + & - & n.d. \\
\hline pSV131-180 & 49 & - & n.d. & n.d \\
\hline pSV131-185 & 54 & - & n.d & n.d \\
\hline pSV131-187 & 56 & + & - & n.d. \\
\hline pSV131-193 & 62 & + & - & n.d. \\
\hline pSV131-196 & 65 & + & + & + \\
\hline pSV131-205 & 74 & - & n.d. & n.d. \\
\hline pSV131-210 & 79 & + & + & + \\
\hline pSV131-214 & 83 & + & + & + \\
\hline pSV131-219 & 88 & + & + & n.d. \\
\hline pSV131-225 & 94 & + & + & + \\
\hline pSV131-230 & 99 & + & - & n.d. \\
\hline pSV131-237 & 106 & + & - & + \\
\hline pSV131-241 & 110 & + & + & + \\
\hline pSV131-249 & 118 & + & + & + \\
\hline pSV131-252 & & + & + & + \\
\hline
\end{tabular}

Tab. 2.3: Ergebnisübersicht aller getesteten L-Konstrukte

Es wurden 18 Mutanten zunächst auf ihre Fähigkeit, das deletierte große Hüllprotein in COS7-Zellen zu exprimieren, überprüft. L-Konstrukte, deren Sezernierung in das Zellmedium nachgewiesen werden konnte, wurden anschließend auf Virionenbildung im Zellmedium von HuH7-Zellen mittels endogener Polymerasereaktion getestet. Mutanten, bei denen der Nachweis des L-Proteins in COS7-Zellen nicht gelang, wurden zunächst nicht weiter überprüft (n.d.).Die Bezeichnung der Mutante gibt die Lage der Deletion wieder (z.B. 131-219 heisst, hier wurde AS 132-218 deletiert).

Aus den vorangegangenen Zellkultur-Experimenten konnten 5 L-Konstrukte isoliert werden, bei denen komplette Virionen im Zellkulturüberstand von HuH7-Zellen mittels der endogenen Polymerasereaktion nachgewiesen werden konnten. Von den übrigen getesteten Mutanten konnte die Expression das L-Proteins entweder gar nicht oder nur im Lysat von 
COS7-Zellen nachgewiesen werden.

Es zeigte sich, dass nur die L-Konstrukte, deren Deletion im Bereich der Aminosäuren 205 bis 230 lagen, überhaupt in der Lage waren, ihr verkürztes Hüllprotein in das Zellmedium von COS7-Zellen zu sezernieren. Von den Mutanten pSV131-196 und pSV131-237 konnte das L-Protein nur im Lysat, nicht jedoch im Medium nachgewiesen werden. Die deletierten großen Hüllproteine der L-Konstrukte, deren Deletionsendpunkt zwischen den Aminosäuren 214 und 230 lag, konnten sowohl im Lysat wie auch im Medium nachgewiesen werden. Daraufhin wurde der Bereich zwischen AS 220 und AS 237 näher untersucht.

\subsection{Konstruktion von Deletionsplasmiden im Bereich von AS 220 bis 237 mittels PCR}

Um zu überprüfen in wie weit man das L-Protein C-terminal verkürzen kann, damit es noch in COS7-Zellen nachgewiesen werden kann und anschließend seine Fähigkeit zu überprüfen, das HBV-Nukleokapsid umhüllen $\mathrm{zu}$ können und komplette Virionen produzieren $\mathrm{zu}$ können, wurden vier weitere Plasmide konstruiert deren Deletionsendpunkte sich im Bereich der Aminosäuren 220 und 237 befanden.. Hierzu wurden erneut mittels PCR Fragmente des Plasmids pSVL amplifiziert. Die senseOligonukleotide wurden wiederum so gewählt, dass ein Thymin am 5'-Ende für die Entstehung eines Kodons für die Aminosäure Leucin nach Ligation der amplifizierten Fragmente mit dem PstI/MBN und SpeI vorbehandelten Plasmid pSVL sorgte. Es konnte bereits nachgewiesen werden, dass die Sekretion subviraler Partikel durch Austausch der positiv geladenen Argininreste an den Aminosärepositionen 245, 251 und 253 des großen Hüllproteins mit ungeladenen Aminosäureresten wie Leucin oder Alanin verhindert wurde $^{[61]}$. Umgekehrt sollte daher die zufällige Entstehung geladener Aminosäurereste nach Religation an der Fusionsstelle ausgeschlossen werden. Die PCR wurde mit dem in Tab. 2.2 angegebenen Temperaturprogramm unter Verwendung des antisense-Oligonukleotids \#244 durchgeführt. Die Länge der entstandenen Fragmente wurde durch Auftragen eines Aliquots jedes Reaktionsansatzes auf ein analytisches Agarosegel überprüft. Nach Aufreinigung der PCR-Produkte mit dem „Qiaquick PCR Purification Kit“ der Firma Qiagen, Hilden, wurden diese anschließend $1 \mathrm{~h}$ mit dem Restriktionsenzym SpeI inkubiert, um ein einheitliches 3'-Ende aller Fragmente zu erhalten. Die Ligation der Fragmente mit dem mit PstI/MBN und SpeI vorbehandelten Plasmid pSVL erfolgte nach deren Isolierung 
aus einem 1\%-igen Agarosegel durch Ausschneiden der Gelstücke und anschließender Aufreinigung mit dem „Qiaquick Gel Extraction Kit“ der Firma Qiagen, Hilden. Nach Inkubation der Ligationsansätze bei $16^{\circ} \mathrm{C}$ für $12 \mathrm{~h}$ wurden diese zur Transformation kompetenter E. coli Zellen benutzt. Die Selektion der so konstruierten Plasmide erfolgte durch Animpfen von $3 \mathrm{ml}$ TB-Amp-Kulturen mit zufällig ausgewählten Kolonien, Anreicherung der DNA in analytischem Maßstab und anschließendem Kontrollverdau mit den Restriktionsenzymen EcoRI und EcoRV. Plasmide deren EcoRI/EcoRV-Fragment kleiner als $1000 \mathrm{Bp}$ war, wurden daraufhin sequenziert und, nachdem sicher gestellt war, dass es sich um die erwartete Sequenz handelte, in präparativem Maßstab angereichert (4.2.2.2).

\subsection{1 Überprüfung der Konstrukte auf Expression des L-Proteins in COS7-Zellen}

Zunächst wurden COS7-Zellen mit je $2 \mu \mathrm{g}$ der neu konstruierten Deletionsplasmide pSV131-222, pSV131-228, pSV131-232 und pSV131-234 transient transfiziert. Am zweiten Tag nach der Transfektion wurde die Hüllproteinbildung durch radioaktive Markierung der Zellen überprüft. Nach Isolierung der Proteine durch Immunpräzipitation aus den lysierten Zellen einer Kulturschale von $2 \mathrm{~cm}$ Durchmesser mit je $1 \mu \mathrm{l}$ anti-HBs wurden sie über ein SDS-Gel aufgetrennt und anschließend mittels Phosphoimager scanning nachgewiesen. In Abb. 2.12 ist der Nachweis der in COS7-Zellen radioaktiv markierten Proteine gezeigt. Es wurden auch für alle vier L-Konstrukte Doppelbanden mit entsprechend ihrer Verkürzung geringeren Molekulargewichten detektiert. Eine Positivkontrolle für das undeletierte L-Protein bei 42 und 39 kDa fehlt in dieser Abbildung. 


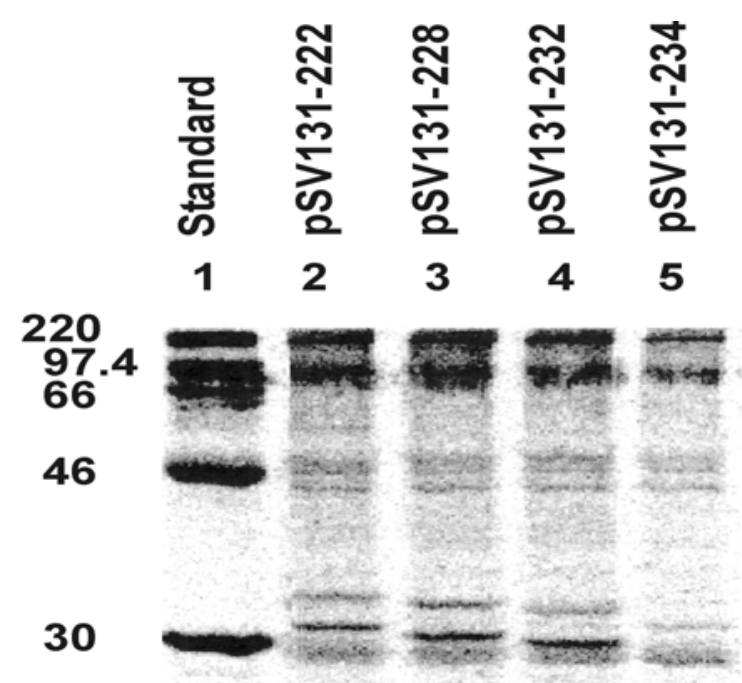

21.5

14.3

Abb. 2.12: Nachweis deletierter L-Proteine nach Transfektion von COS7-Zellen

Nach eintägiger Exposition des getrockneten Gels erfolgte die Analyse mittels Phosphoimager scanning. In Spur 1 ist der ${ }^{14} \mathrm{C}$-markierte Proteinstandard aufgetragen. Die Zahlen links bezeichnen die Molekulargewichte der Proteine des Standards. Die übrigen vier Spuren wiesen Doppelbanden der verkürzten L-Proteine für ihre unglykosylierte und glykosylierte Form oberhalb von $30 \mathrm{kDa}$ auf.

\subsection{2 Überprüfung der Sezernierung deletierter L-Proteine nach Cotransfektion von COS7-Zellen}

Nachdem es gelungen war, die Synthese der deletierten großen Hüllproteine der vier Konstrukte im Lysat von COS7-Zellen nachzuweisen, wurde überprüft, ob der Einbau der so deletierten L-Proteine in subvirale Partikel ebenfalls noch stattfand und diese auch im Zellmedium nachzuweisen waren. Um dies zu überprüfen, wurden COS7-Zellen mittels DEAE-Dextran transient cotransfiziert. Die L-Konstrukte wurden zusammen mit dem Sexprimierenden Plasmid pSVX24H in einem Mengen-Verhältnis von 5:1 eingesetzt. Zwei Tage nach der Transfektion wurde die Expression des großen Hüllproteins durch radioaktive Markierung im Pulse-Chase-Experiment (4.2.4.4) untersucht. Die radioaktive Markierung erfolgte durch Einbau von ${ }^{35}$ S-markiertem Cystein/Methionin. Nach einem 
weiteren Tag wurden sowohl die Zelllysate wie auch die Zellkulturüberstände mit je $1 \mu 1$ anti-HBs immunpräzipitiert. Nach Auftrennung der Proteine über SDS-PAGE (4.2.4.6) erfolgte der Nachweis der deletierten L-Proteine mittels Autoradiographie (4.2.4.8).

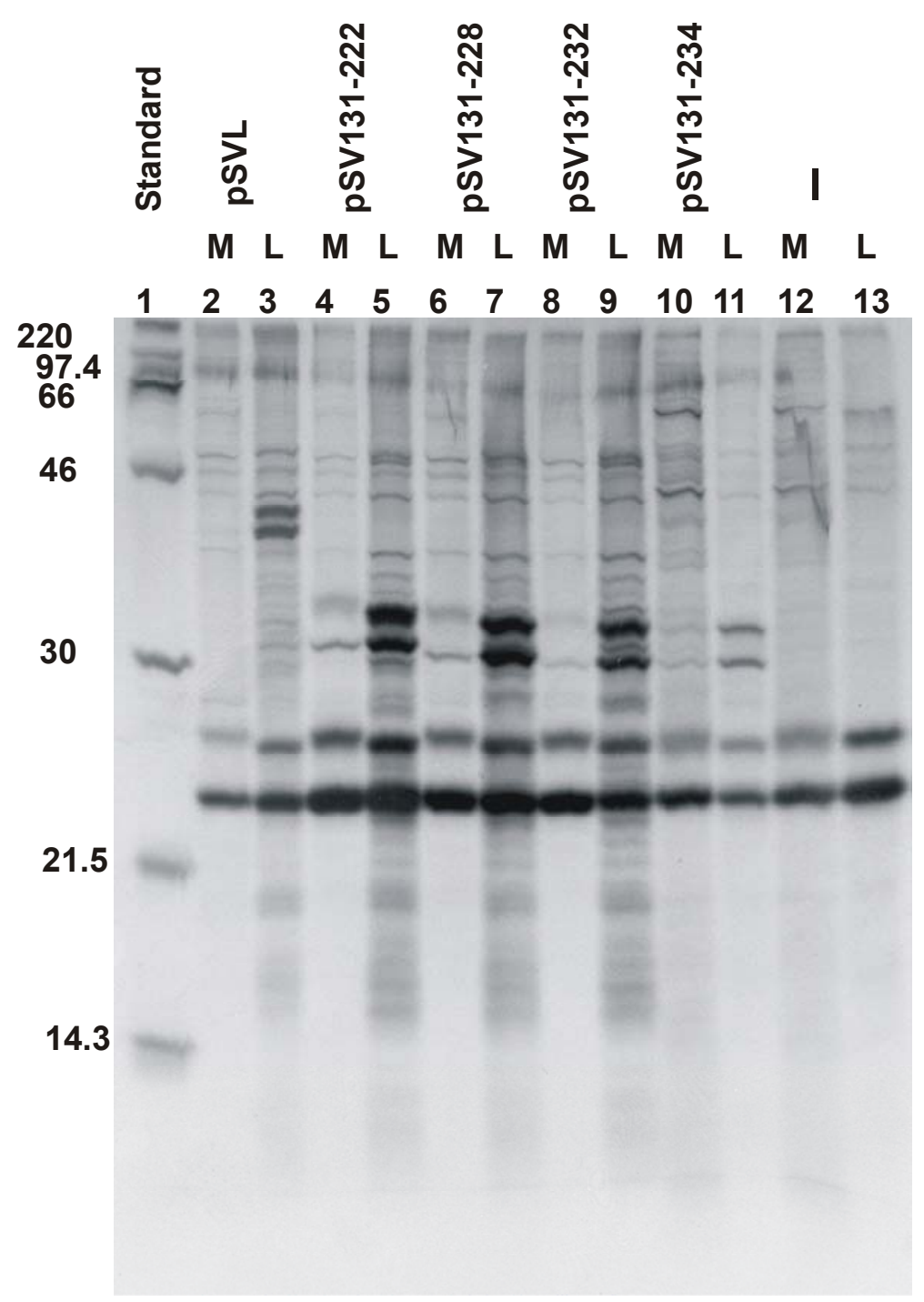

Abb. 2.13: Nachweis der L-Proteinbildung in Zelllysat- und Medium von COS7-Zellen nach Cotransfektion mit pSVBX24H

Die Entwicklung des Autoradiogramms erfolgte nach 4-tägiger Exposition des Gels bei $-70^{\circ} \mathrm{C}$. In Spur 1 ist der ${ }^{14} \mathrm{C}$-markierte Proteinstandard aufgetragen. Die Zahlen links geben die Molekulargewichte der Proteine des Standards wieder. Spuren mit gerader Nummerierung (2, 4, 6 u.s.w) enthielten die Zellkulturüberstände, Spuren mit ungerader Nummerierung ( $3,5,7$, u.s.w) die Zelllysate. In den Spuren 12 und 13 wurden die Proteine nach Transfektion der COS7-Zellen mit pSVBX24H allein aufgetragen. Alle Spuren wiesen erwartungsgemäß das S-Protein in seiner glykosylierten und unglykosylierten Form bei 24 und $27 \mathrm{kDa}$ auf. Es wurden außerdem für alle verkürzten L-Konstrukte Doppelbanden sowohl im Lysat wie auch im Medium detektiert. 
Abb. 2.13 zeigt neben der zu erwartetenden Doppelbande für das undeletierte L-Protein von pSVL im Lysat auch für die übrigen L-Konstrukte Doppelbanden mit entsprechend geringeren Molekulargewichten. Es konnten außerdem alle vier deletierten L-Proteine auch im Zellkulturüberstand nachgewiesen werden. Die Doppelbanden der Plasmide pSV131232 und pSV131-234 im Medium waren jedoch in ihrer Intensität etwas schwächer, als die der beiden anderen L-Konstrukte. Somit konnte nachgewiesen werden, dass Deletionen im Bereich zwischen den Aminosäuren 205 und 234, mit Ausnahme des Konstrukts pSV131210, die Synthese des großen Hüllproteins und seine Sezernierung in das Zellmedium nicht verhindern. Es sollte nun überprüft werden, ob die neu erzeugten Deletionsplasmide ebenfalls in der Lage waren das HBV-Nukleokapsid zu umhüllen und zur Sekretion komplette Virionen in das Zellmedium beizutragen.

\subsection{Nachweis kompletter Virionen durch endogene Polymerasereaktion nach Cotransfektion von HuH7-Zellen}

Zur Überprüfung der vier Deletionsplasmide auf Synthese funktioneller Nukleokapside und Nachweis der Sekretion kompletter Virionen, wurden HuH7-Zellen mit je $1 \mu \mathrm{g}$ pSVHBV1.5L $\mathrm{L}^{-}$und jeweils $1 \mu \mathrm{g}$ des L-Konstrukts mittels der $\mathrm{CaCl}_{2}$-Methode transfiziert (4.2.3.4). Zusätzlich wurde die Mutante pSV131-237 in diesem Experiment mitgeführt, bei der der Nachweis des großen Hüllproteins in sezernierten subviralen Partikeln nicht gelungen war. Um zu überprüfen, ob dieses Negativergebnis eventuell auf mangelnde Empfindlichkeit des Nachweissystems zurückzuführen war, sollte das Vorhandensein kompletter Virionen im Zellmedium durch endogene Polymerasereaktion (4.2.4.9) untersucht werden. Fünf Tage nach der Transfektion wurden die Lysate und Zellkulturüberstände geerntet und mit je $1 \mu \mathrm{l}$ anti-HBc (Zelllysat) und anti-HBs (Zellmedium) immunpräzipitiert. Die $3 \times$ mit PBS gewaschenen Präzipitate wurden einer endogenen Polymerasereaktion unterzogen. Die radioaktiv markierte DNA wurde durch Phenol-Chloroform-Extraktion und zweimaliger $\mathrm{NH}_{4} \mathrm{Ac}$ /Ethanol-Fällung gereinigt. Das DNA-Pellet wurde in $10 \mu 1$ TE-Puffer resuspendiert und mit $2 \mu 16 \times$ Probenauftragspuffer (4.1.1) versehen. Zur Detektion funktioneller Nukleokapside und sekretierter Virionen wurden die Proben getrennt nach Lysat und Medium auf zwei 1\%-ige Agarosegele aufgetragen. Nach zweistündiger Elektrophorese bei $100 \mathrm{~V}$ wurden die Gele unter Vakuum 
bei $70^{\circ} \mathrm{C}$ getrocknet. Die radioaktiv markierte virale DNA in den Kapsiden (Abb. 2.14.a) und den Virionen (2.14.b) wurde durch Autoradiographie nachgewiesen.

\section{a) Lysate}

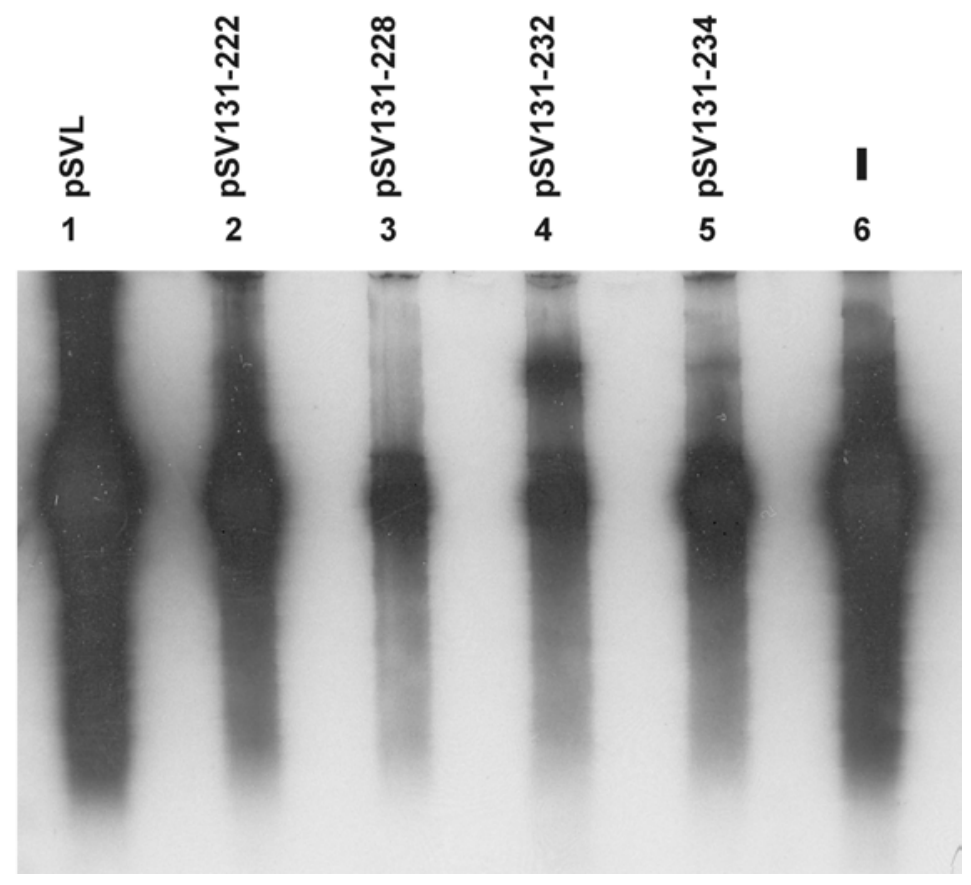

Abb. 2.14.a: Nukleokapsid-Nachweis aus Zelllysaten von HuH7-Zellen.

In die endogene Polymerasereaktion, durch die HBV-DNA in Nukleokapsiden radioaktiv markiert wird, wurde das Lysat und das Medium von den mit den LKonstrukten und pSVHBV1.5 $\mathrm{L}^{-}$cotransfizierten HuH7-Zellen eingesetzt. Abb. 2.14.a zeigt den Nachweis funktioneller Nukleokapside aus den Lysaten sowohl von der mitgeführten Positivkontrolle pSVL (Spur 1), wie auch von allen untersuchten deletierten L-Konstrukten (Spuren 2-5). Spur 6 zeigt das Lysat der nur mit pSVHBV1.5 $\mathrm{L}^{-}$allein transfizierten Zellen.

Die Signale der 4 deletierten L-Konstrukte aus dem Zelllysat zeigten an, dass die Bildung intakter Nukleokapside nach Cotransfektion mit pSVHBV1.5 $\mathrm{L}^{-}$möglich war. Für die Reaktionsansätze aus den Zellkulturüberständen konnte neben der mitgeführten Positivkontrolle des nicht deletierten großen Hüllproteins in pSVL sehr schwache Signale von den Deletionsplasmiden erhalten werden, so dass diese in der Lage waren, das Kapsid $\mathrm{zu}$ umhüllen und komplette Virionen aus der Zelle in das Medium zu sekretieren (Abb. 2.14.b) 


\section{b) Zellkulturüberstände}

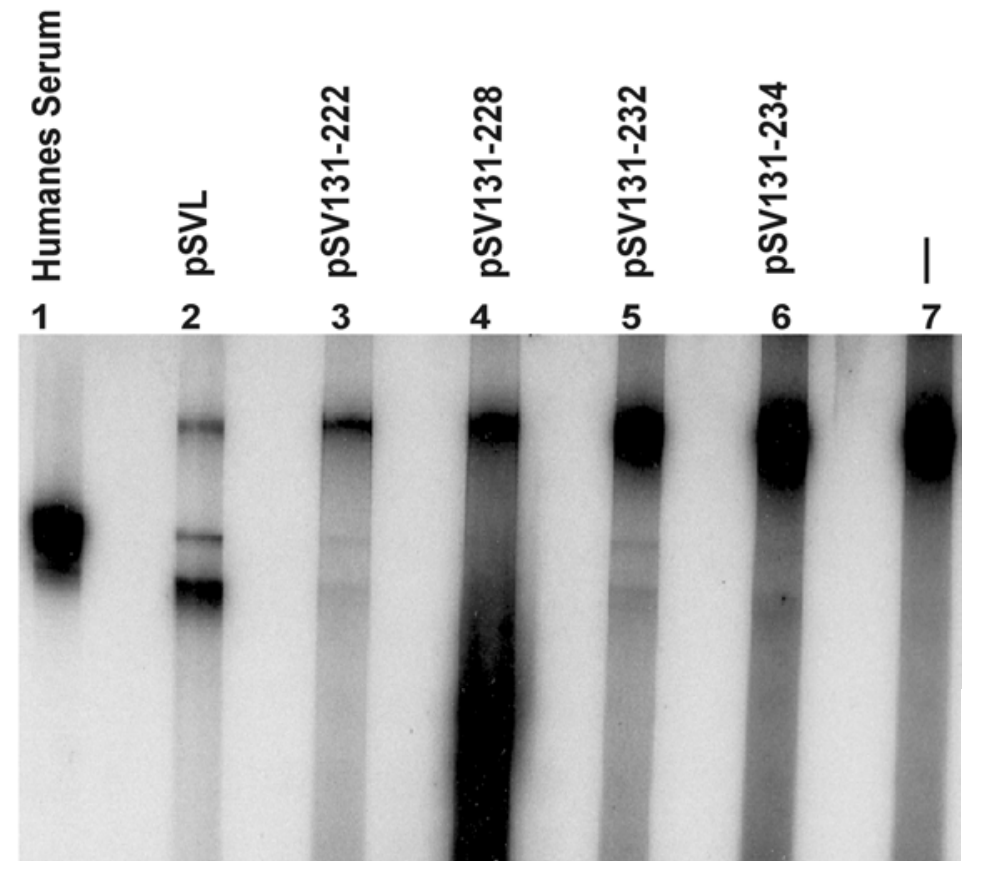

Abb. 2.14.b: Nachweis von Virionen aus dem Zellmedium transfizierter HuH7-Zellen

Die Detektion der Signale für die gebildeten Virionen nach Cotransfektion von HuH7Zellen mit pSVHBV1.5L' und pSVL (Spur 2) sowie den 4 L-Konstrukten (Spuren 3-6) erfolgte nach 5-tägiger Exposition des Gels bei $-70^{\circ} \mathrm{C}$. In Spur 7 wurde nach Transfektion mit pSVHBV1.5L allein erwartungsgemäß kein Signal erhalten. In Spur 1 ist radioaktiv markierte HBV-DNA aus humanem Serum aufgetragen.

\subsection{Bedeutung der in das L-Protein eingeführten Deletionen für die Sekretion subviraler Partikel}

Zahlreiche animale Viren besitzen eine lipidhaltige Hülle, die viruskodierte transmembrane Glykoproteine enthält. Sie spielt im Vermehrungszyklus dieser Viren eine wichtige Rolle, da sie sowohl an der Ausschleusung reifer Virionen aus der infizierten Zelle wie auch an deren Aufnahme durch weitere Wirtszellen beteiligt ist. Man geht davon aus, dass die Bildung des Hepatitis B Virions durch direkte Interaktion zwischen den viralen Hüllproteinen und dem entstehenden viralen Nukleokapsid vermittelt wird. Im Gegensatz $\mathrm{zu}$ einigen anderen Virusfamilien, wie den Retroviren, besitzt das Hepatitis B Virus kein sogenanntes Matrixprotein, dass die Interaktion zwischen Nukleokapsid und Hülle vermittelt $^{[62]}$. Prinzipiell sind zytoplasmatisch lokalisierte Domänen von Hüllproteinen zu einer solchen Interaktion in der Lage. So konnte beispielsweise für das Semliki Forest Virus (SFV) gezeigt werden, dass eine direkte Wechselwirkung zwischen dem E2Oberflächenprotein und dem Nukleokapsid stattfindet, die für dessen Umhüllung 
unerläßlich ist ${ }^{[63]}$. Bei dem Hepatitis B Virus ist der große N-terminale Bereich des LProteins auf der zytosolischen Seite der ER-Membran lokalisiert. In früheren Arbeiten konnte bereits gezeigt werden, dass die Veränderung der transmembranen Topologie durch Einführen einer „Signalsequenz“ an den N-Terminus des L-Proteins, die eine luminale Exposition der PräS-Domänen bewirkt, zwar weiterhin die Synthese subviraler Partikel sowie reifer Core-Partikel, erlaubt aber die Bildung von kompletten Virionen verhindert ${ }^{[53]}$. Desweiteren konnte gezeigt werden, dass die N-terminalen 97 Aminosäuren deletiert werden können, ohne dass dies die Virusmorphogenese inhibiert ${ }^{[57]}$, jedoch die Substitution des Bereiches zwischen Aminosäure 98 und 124 die Virionenbildung nicht mehr gestattet $^{[59]}$. Diese Ergebnisse demonstrieren die Bedeutung der zytoplasmatischen Exposition der Domäne von Aminosäure 98 bis zum Beginn des Signals II bei Aminosäure 253.

In der vorliegenden Arbeit sollte daher untersucht werden, in wie weit sich weiter Cterminal von Aminosäure 124 befindliche Mutationen auf die Bildung subviraler Partikel und kompletter Virionen auswirken. Es wurden daher zunächst über einen weiten Bereich des L-Proteins, der sowohl die PräS2- wie auch die S-Domäne umfasste, ungerichtete Mutationen in der Sequenz erzeugt (2.1). Die Mutagenese wurde in einem, von den im LGen natürlich vorkommenden Restriktionsschnittstellen PstI (nt 21) und SpeI (nt 677) begrenzten, Sequenzabschnitt durchgeführt. Der erste Schritt war die Spaltung des Plasmids pSVL mit dem Restriktionsenzym PstI. Durch den exonukleolytischen Abbau in die Enden der linearisierten DNA hinein, anschließender Behandlung mit dem Restriktionsenzym SpeI und der folgenden Religation entstanden Deletionen im Bereich der beiden Schnittstellen. Die Aminosäure an der Fusionsstelle konnte von der Wildtypsequenz abweichen und durch eine beliebige andere ersetzt sein. Daraufhin wurde überprüft, ob die so verkürzten großen Hüllproteine in subvirale Partikel eingebaut werden konnten und durch Sezernierung im Medium nachweisbar waren. Dieser Nachweis wurde durch Cotransfektion von COS7-Zellen mit dem S-exprimierenden Plasmid pSVBX24H durchgeführt. Durch radioaktive metabolische Markierung und anschließende Immunpräzipitation mit einem polyklonalen Serum, welches die Antigenitäten aller drei Hüllproteine erkennt, konnten alle Proteinformen der verkürzten L-Konstrukte in Gegenwart des kleinen Hüllproteins im Zellkulturüberstand detektiert werden. Von den zuvor durch Sequenzierung genotypisch charakterisierten L-Konstrukten wurden zunächst elf zur Transfektion von COS7-Zellen eingesetzt (2.2.1). Die Hüllproteinbildung konnte bei 8 der 11 L-Konstrukte im Zelllysat nachgewiesen werden. Bei den drei Plasmiden, bei 
denen der Nachweis des L-Proteins nicht gelang, lagen die Endpunkte der Deletion jeweils im Bereich der transmembranen Signalsequenz I. Die vor dieser Domäne deletierten Hüllproteine und ebenfalls auch diejenigen, deren hydrophobe Signalsequenz komplett deletiert war, konnten im Lysat nachgewiesen werden. Es konnten jedoch wiederum nur 2 von ihnen, wahrscheinlich in subvirale Partikel eingebaut, im Medium nachgewiesen werden (2.2.2). Eine Möglichkeit der Erklärung bestand darin, dass die Deletion eine inkorrekte Faltung des Proteins bewirkte und es somit am ER zurückgehalten wurde. Daher kamen diese L-Konstrukte für die Überprüfung auf Bildung kompletter Virionen nicht in Frage. Es wurden daraufhin durch PCR gezielt weitere Deletionen in dem Aminosäurebereich eingeführt, in dem die Sezernierung der zuvor überprüften L-Proteine in das Medium nachgewiesen werden konnte. An der Fusionsstelle wurde ein Kodon für die Aminosäure Leucin erzeugt, um das zufällig Entstehen geladener Aminosäurereste zu verhindern. Es konnte bereits gezeigt werden, dass Verkürzungen von 4 bis 6 Aminosäuren im N-terminalen Bereich des kleinen Hüllproteins bis Aminosäureposition 55 die Sekretion des S-Proteins nicht beeinflusst, Deletionen ähnlicher Größe im Bereich der Aminosäuren 57 und 78 jedoch die S-Protein-Synthese und/ oder die Protein-Stabilität schwächen ${ }^{[64]}$. Entsprechend wurden sieben weitere Deletionsmutanten erzeugt deren Endpunkte im Bereich der Aminosäuren 205-252 lagen, was der Domäne zwischen den Aminosäuren 42 und 89 im kleinen Hüllprotein entspricht. In Übereinstimmung mit den für das S-Protein gewonnen Erkentnissen konnten die L-Proteine der Konstrukte pSV131-237, pSV131-241 und pSV131-252 nur im Lysat nicht aber in im Medium nachgewiesen werden, wohingegen es gelang, 3 der 4 im N-Terminus der S-Schleife verkürzten L-Proteine auch im Medium nachzuweisen. Das deletierte L-Protein des Konstrukts pSV131-210 war aus unbekannten Gründen nicht nachweisbar. Durch anschließende Erzeugung von 4 weiteren deletierten LKonstrukten mittels PCR konnte gezeigt werden, dass L-Proteine mit Deletionsendpunkten zwischen Aminosäure 205 und 234, mit Ausnahme des Konstrukts pSV131-210, noch im Zellmedium nachgewiesen werden konnten (2.8.2). Bei den erzeugten L-Proteine ab einem Deletionsendpunkt bei Aminosäure 237 gelang dieser Nachweis nicht mehr. Zur Übersicht sind in Abb. 2.15 alle in COS7-Zellen phänotypisch charakterisierten L-Konstrukte mit ihren Deletionsanfangs- und -endpunkten gezeigt. 


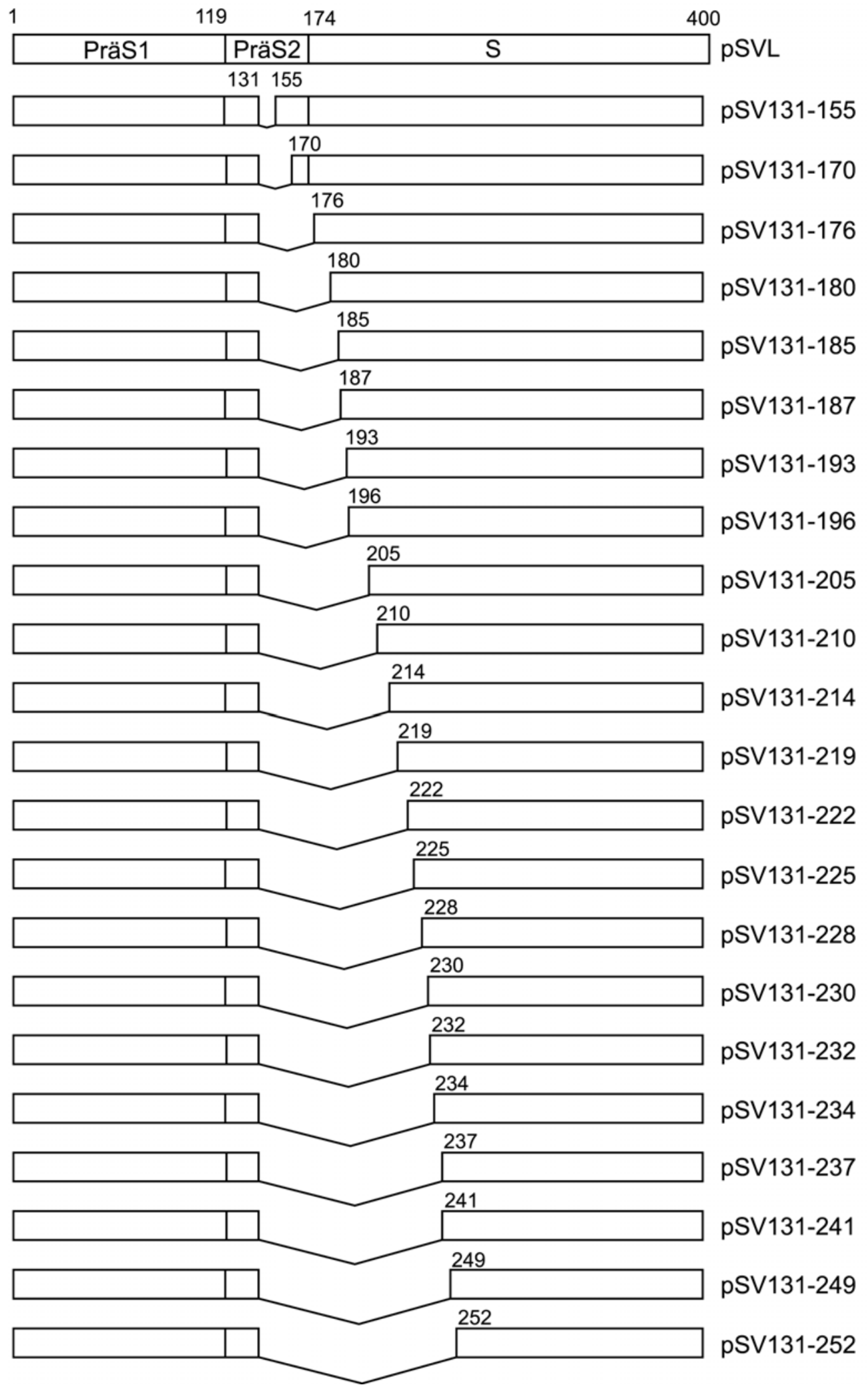

Abb. 2.15: Übersicht über alle erzeugten und in COS7-Zellen phänotypisch charakterisierten LKonstrukte. 


\subsection{Einfluss der deletierten L-Proteine auf die Virusbildung}

Die eingeführten Deletionen in das große Hüllprotein des HBV ergaben eine Einteilung in vier verschiedene Bereiche. L-Konstrukte, deren Deletionsendpunkte vor der Domäne der transmembranen hydrophoben Signalsequenz I lagen (pSV131-155, pSV131-170 und pSV131-176), konnten in ihrer glykosylierten und unglykosylierten Form im Lysat von COS7-Zellen nachgewiesen werden, jedoch wurden sie nicht in sekretierte subvirale Partikel eingebaut. Die verkürzten L-Proteine mit Deletionsendpunkten innerhalb dieser Domäne (pSV131-180, pSV131-185 und pSV131-187) konnten weder im Medium noch im Lysat von COS7-Zellen nachgewiesen werden mit Ausnahme des Konstrukts pSV131-193, welches zwei schwache Banden auf dem Autoradiogramm aufwies. Die Deletionsendpunkte der Plasmide, deren L-Protein sowohl im Lysat wie auch im Medium nachgewiesen werden konnte, erstreckten sich auf den Aminosäurebereich 205-234. Die Proteine der Deletionsplasmide mit einem Endpunkt ab Aminosäure 237 bis zum Anfang von Signal II konnten wiederum nur in den Lysaten detektiert werden.

Obwohl das L-Protein über alle Hüllproteindomänen verfügt, konnte in Untersuchungen zur Virusmorphogenese nachgewiesen werden, dass zur Bildung kompletter Virionen die Anwesenheit des S-Proteins unerlässlich ist ${ }^{[56][65]}$. Mit einem Peptid-Bindungsansatz konnte später gezeigt werden, dass die Aminosäuren 56-80 des S-Proteins an das Nukleokapsid banden $^{[66]}$. Es sollte daher mit den deletierten L-Proteinen, deren Nachweis im Zellkulturüberstand gelungen war, überprüft werden, ob das große Hüllprotein ebenfalls über eine Domäne verfügt, die direkt mit dem Nukleokapsid in Wechselwirkung tritt und somit die Bildung von Virionen unterstützt.

Hierzu wurden HuH7-Zellen mit den Konstrukten pSV131-205, pSV131-214, pSV131219, pSV131-222, pSV131-225, pSV131-228, pSV131-230, pSV131-232 und pSV131-234 zusammen mit einem HBV-Genom, das kein L-Protein exprimieren kann, cotransfiziert. Durch anschließende endogene Polymerasereaktion konnte in den Lysaten die Bildung intakter Nukleokapside für alle Transfektionen nachgewiesen werden. Es wurden Signale mit vergleichbarer Stärke zur mitgeführten Positivkontrolle pSVL erhalten. (Abb. 2.10.a und 2.14.a). Die für die Virionenbildung erhaltenen Ergebnisse machen deutlich, dass Deletionen in diesem Bereich eine Umhüllung des Kapsids zuließen und komplette Virionen im Zellmedium nachgewiesen werden konnten. Es konnte jedoch eine Abschwächung der Signale beobachtet werden. Die radioaktiv markierte virale DNA konnte von den Konstrukten pSV131-205, pSV131-214 und pSV131-219 mit ähnlich starker Intensität detektiert werden wie bei der Cotransfektion mit dem undeletierten L- 
Protein. Konstrukte, deren Deletionen weiter C-terminal angesiedelt waren, wiesen erheblich schwächere Signale auf. Nach Abtrennung nackter Core-Partikel mittels CsClGradientendichtezentrifugation aus dem Zellkulturüberstand der mit dem Deletionsplasmid pSV131-230 cotransfizierten HuH7-Zellen, konnte das Signal für die Virionen enthaltende Fraktion im Vergleich zur Positivkontrolle mit nur etwa 1\%-iger Intensität detektiert werden (Abb. 2.11).

Legt man für das S-Protein und die S-Domäne des großen Hüllproteins die gleiche Topologie zu Grunde, würde dieses Ergebnis im Widerspruch zu der Tatsache stehen, dass Deletionen im Bereich von AS 56-61 des S-Proteins die Bildung von Virionen verhindern. Die Deletion des entsprechenden Bereichs von AS 229-234 im großen Hüllprotein konnte die Virusproduktion zwar hemmen, jedoch nicht unterbinden. Vor kurzem konnte jedoch die Existenz topologischer Unterschiede zwischen der S-Domäne von L und dem S-Protein mit Hilfe eines bisher uncharakterisierten monoklonalen anti-S Antikörpers gezeigt werden $^{[67]}$.

Um auszuschließen, dass weiter C-terminal deletierte Plasmide nicht vielleicht doch in der Lage waren, die Virusbildung zu unterstützen und nur durch mangelnde Empfindlichkeit des Nachweissystems nicht im Medium von COS7-Zellen detektiert werden konnten, wurde zusätzlich das Plasmid pSV131-237 bei Prüfung auf Reproduzierbarkeit der Ergebnisse in bezug auf die Synthese kompletter Virionen in die Cotransfektion von HuH7Zellen, neben den bereits getesteten Deletionsplasmiden, eingesetzt. Es konnte jedoch kein Signal für dieses Konstrukt detektiert werden (Daten nicht gezeigt).

\subsection{Auswirkung des durch die eingeführten Deletionen veränderten Abstands zwischen ER-Membran und der Domäne von AS 98-124}

Durch frühere Untersuchungen der N-terminalen Region des großen Hüllproteins konnte bereits nachgewiesen werden, dass eine kleine Domäne im PräS-Bereich des L-Proteins zwischen AS 98-124 bei der Umhüllung des Nukleokapsids eine essentielle Rolle spielt ${ }^{[59]}$. Durch Einführung von Deletionen mit einem Anfangspunkt, der 7 AS C-.terminal dieser bereits kartierten Region liegt und Verkürzung der cytosolischen S-Schleife um bis zu 121 AS, sollte in dieser Arbeit überprüft werden, in wie weit die daraus resultierende Veränderung des Abstands zwischen der ER-Membran und der für die Umhüllung notwendigen PräS-Domäne bei der Virusbildung toleriert wird. Durch die sukzessive 
Einführung von Deletionen sollte nachgewiesen werden welcher Mindestabstand zur ERMembran gewahrt bleiben musste, damit die PräS-Domäne noch in der Lage ist, die potentielle Kontaktstelle auf der Kapsidoberfläche zu erreichen.

Getestet wurden zunächst nur L-Konstrukte die nach Transfektion von COS7-Zellen nach radioaktiver metabolischer Markierung nachweisbar waren. Wie bereits erwähnt, gelang dies nur bei Konstrukten, deren Deletionsendpunkte im Bereich zwischen AS 205 und 234 lagen. Durch anschließende endogene Polymerasereaktion sollte der Nachweis auf Virusbildung erbracht werden. Die Detektion kompletter Virionen gelang bis zu einer Verkürzung der S-Schleife um 103 AS. Weiter C-terminal deletierte L-Konstrukte konnten nicht im Medium von COS7-Zellen nachgewiesen werden. Der Nachweis auf Virionen nach Transfektion von HuH7-Zellen und anschließender endogener Polymerasereaktion verlief ebenfalls negativ.

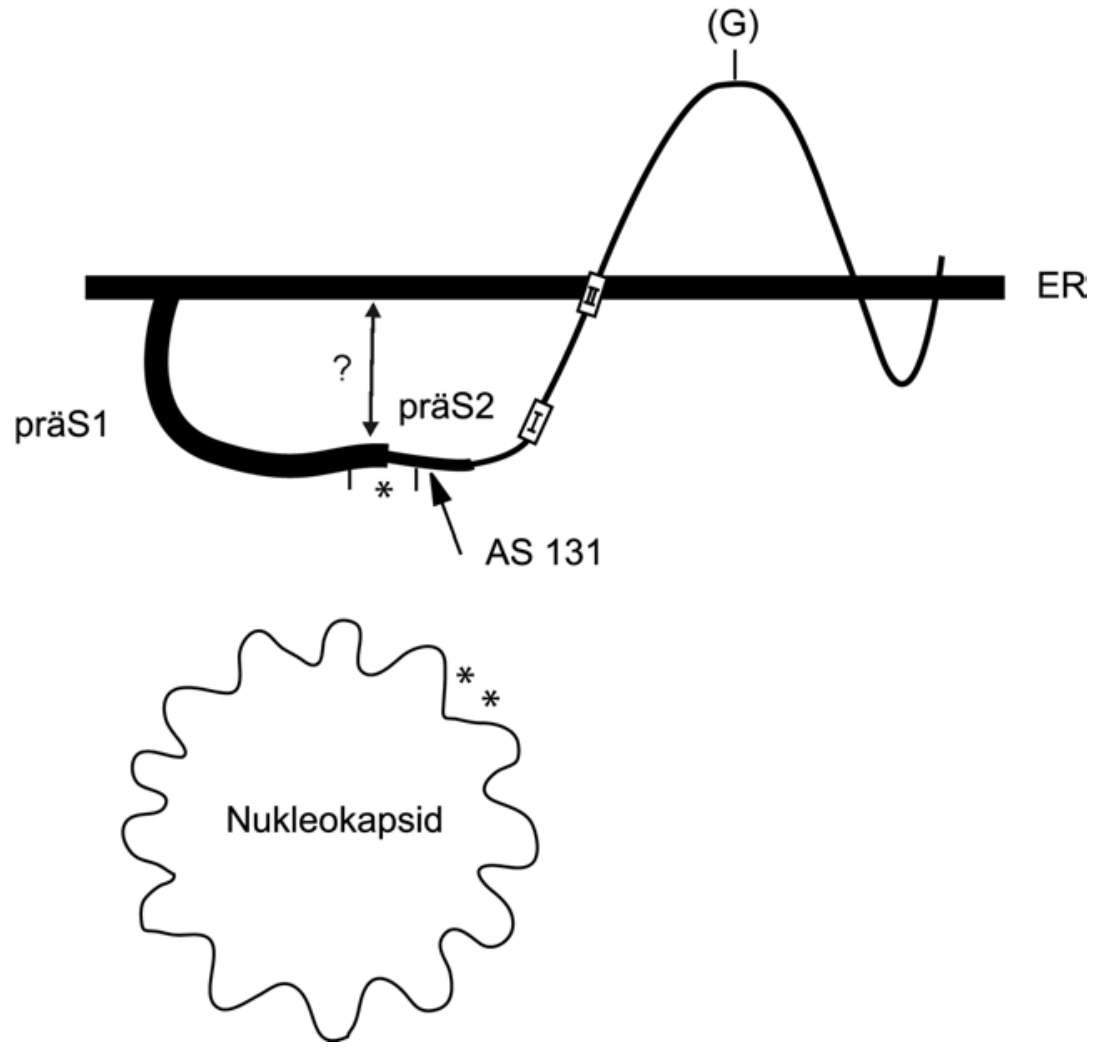

Abb. 2.16: Modell der in Wechselwirkung tretenden Domänen von L-Protein und Nukleokapsid.

Die Abbildung zeigt eine vereinfachte Darstellung von L-Protein und Nukleokapsid. Die mit einem $*$ gekennzeichnete Region zwischen AS 98-124 interagiert direkt mit einer möglichen Kontaktstelle am Nukleokapsid (**) bei dessen Umhüllung. Der Pfeil kennzeichnet den Anfangspunkt der in dieser Arbeit in das L-Protein eingeführten Deletionen. Die Endpunkte wurden in einer Region von AS 155 bis zum Beginn der Signalsequenz II (AS 253) angesiedelt. Der Doppepfeil kennzeichnet den Abstand zwischen ER-Membran und der Kontaktstelle zum Nukleokapsid. 
Mit den vorliegenden Ergebnissen konnte gezeigt werden, dass ein Abstand von nur 26 Aminosäuren von der ER-Membran für Domäne zwischen AS 98-124 noch ausreichend ist, um mit dem Kapsid in Wechselwirkung treten zu können und die Sekretion kompletter Virionen aus der Zelle zu ermöglichen.

\subsection{Ausblick}

Für den komplexen Vorgang der Virusbildung konnte bereits eine direkte Interaktion einer kleinen Domäne des S-Proteins und dem Bereich zwischen AS 98-124 der PräS2-Domäne des großen Hüllproteins mit dem Nukleokapsid nachgewiesen werden. Die Ergebnisse der vorliegenden Arbeit legen die Vermutung nahe, dass die hier untersuchte Region des großen Hüllproteins von AS 170 bis 252 keine unmittelbare Rolle im Verpackungsprozeß des Kapsids spielt. Dies könnte zum einen erklären, warum das L-Protein allein nicht für das Virus Assembly ausreicht, sondern die Anwesenheit von S benötigt und zum anderen geben sie einen weiteren Hinweis darauf, dass das S-Protein und die S-Domäne des großen Hüllproteins unterschiedliche Topologien aufweisen. Es konnte jedoch durch sukzessive Verkürzung der S-Schleife und der damit einhergehenden Veränderung des Abstandes zwischen der ER-Membran und der für die Umhüllung des Kapsids essentiellen Region gezeigt werden, dass ein Abstand von 26 Aminosäuren ausreichend ist, um den Kontakt zum Kapsid herzustellen. In Ermangelung einer Röntgenkristallstruktur kann über die konformative Natur der Hüllproteine weiterhin nur spekuliert werden. 


\section{Zusammenfassung}

In der vorliegenden Arbeit sollte durch phänotypische Charakterisierung von deletierten L-Protein-Konstrukten die Bedeutung der noch nicht charakterisierten Domäne von AS 170 bis 253 des großen Hüllproteins des Hepatitis B Virus für die Bildung kompletter Virionen aufgeklärt werden.

Hierzu wurden die erzeugten Deletionsplasmide zunächst auf ihre Fähigkeit hin überprüft, im Lysat und Zellkulturüberstand von COS7-Zellen durch radioaktive metabolische Markierung stabil exprimiert zu werden. Es zeigte sich, dass vor allem Deletionen, die im Bereich der hydrophoben transmembranen Signalsequenz I eingeführt wurden, die Expression gänzlich verhinderten. Die so deletierten großen Hüllproteine konnten weder im Lysat noch im Zellkulturüberstand nachgewiesen werden.

Der Nachweis deletierter L-Proteine im Zellmedium gelang nur bei den Konstrukten, deren Deletionsendpunkte im Bereich von AS 205-243 lagen.

Es konnte außerdem in Cotransfektionsversuchen mit einem HBV-Genom, welches einen L-Defekt aufwies, in HuH7-Zellen gezeigt werden, dass alle verkürzten L-Proteine, die im Zellkulturüberstand von COS7-Zellen nachgewiesen werden konnten, auch zur transKomplementation des L-Dekfekts durch Nachweis sezernierter Viren befähigt waren. Die Quantifizierung der gebildeten Virionen ergab jedoch, dass im Vergleich zum nicht deletierten L-Protein die Virusbildung durch deletierte L-Konstrukte stark eingeschränkt war.

Ein Nachweis auf direkte Interaktion des in dieser Arbeit untersuchten Bereichs des großen Hüllproteins mit dem Hepatitis B Virus-Nukleokapsid konnte nicht erbracht werden.

Durch die in die S-Schleife eingeführten Deletionen, die eine Abstandsveränderung zwischen der ER-Membran und der für die Umhüllung des Kapsids notwendige PräSDomäne von AS 98-124 zur Folge hatte, war es möglich zu zeigen, dass bis zu einem Abstand von 26 Aminosäuren eine Umhüllung des Kapsids, durch Nachweis sekretierter Virionen im Medium,stattfand. 


\section{Experimenteller Teil}

\subsection{Material}

\subsubsection{Reagenzien, Lösungen und Puffer}

Die verwendeten Lösungsmittel und Salze sowie die gebräuchlichen Laborchemikalien wurden im Reinheitsgrad „,zur Analyse“ oder „reinst“, und soweit im Text nicht anders vermerkt von den Firmen Biometra (Göttingen), Boehringer (Mannheim), Merck (Darmstadt), Paesel \& Lorei (Frankfurt), Serva (Heidelberg) oder Sigma ( Deisenhofen) bezogen. Lösungen wurden generell mit doppelt destilliertem Wasser hergestellt.

\begin{tabular}{|c|c|c|}
\hline Puffer/ Lösungen & Zusammensetzung & Konzentration \\
\hline \multirow[t]{2}{*}{ Coomassie-Entfärber } & Methanol & $10 \%(\mathrm{v} / \mathrm{v})$ \\
\hline & Essigsäure & $5 \%(\mathrm{v} / \mathrm{v})$ \\
\hline \multirow[t]{3}{*}{ Coomassie-Färbebad } & Methanol & $50 \%(\mathrm{v} / \mathrm{v})$ \\
\hline & Essigsäure & $10 \%(\mathrm{v} / \mathrm{v})$ \\
\hline & Coomassie Brilliant Blue & $0,1 \%(\mathrm{w} / \mathrm{v})$ \\
\hline \multirow[t]{3}{*}{ HBS $(10 x), p H 7,1$} & $\mathrm{NaCl}$ & $1,4 \mathrm{M}$ \\
\hline & HEPES & $250 \mathrm{mM}$ \\
\hline & $\mathrm{Na}_{2} \mathrm{HPO}_{4} \times 2 \mathrm{H}_{2} \mathrm{O}$ & 7,5 mM \\
\hline Laufpuffer $(10 \mathrm{x})$ & Tris & $0,25 \mathrm{M}$ \\
\hline \multirow[t]{2}{*}{ für SDS-PAGE } & Glycin & $1,92 \mathrm{M}$ \\
\hline & SDS & $1 \%(\mathrm{w} / \mathrm{v})$ \\
\hline \multirow{3}{*}{$\begin{array}{l}\text { Lösung I } \\
\text { für die Plasmidpräparation }\end{array}$} & Glucose & $50 \mathrm{mM}$ \\
\hline & Tris-HCl, $\mathrm{pH} 8,0$ & $25 \mathrm{mM}$ \\
\hline & Na-EDTA, $\mathrm{pH} 8,0$ & $10 \mathrm{mM}$ \\
\hline Lösung II & $\mathrm{NaOH}$ & $0,2 \mathrm{~N}$ \\
\hline für die Plasmidpräparation & SDS & $1 \%(\mathrm{w} / \mathrm{v})$ \\
\hline Lösung III & $\mathrm{K}^{+}$ & $3 \mathrm{M}$ \\
\hline für die Plasmidpräparation & $\mathrm{Ac}^{-}$ & $5 \mathrm{M}$ \\
\hline
\end{tabular}




\begin{tabular}{|c|c|c|}
\hline $\begin{array}{l}\text { Lösung IV } \\
\text { für die Plasmidpräparation }\end{array}$ & $\mathrm{LiCl}$ & $5 \mathrm{M},-20^{\circ} \mathrm{C}$ \\
\hline $\begin{array}{l}\text { Lösung V } \\
\text { für die Plasmidpräparation }\end{array}$ & RNAse A & $20 \mu \mathrm{g} / \mathrm{ml}$ in $1 \times \mathrm{TE}$ \\
\hline $\begin{array}{l}\text { Lösung VI } \\
\text { für die Plasmidpräparation }\end{array}$ & $\begin{array}{l}\text { Polyethylenglycol } 6000 \\
\mathrm{NaCl}\end{array}$ & $\begin{array}{l}13 \%(\mathrm{w} / \mathrm{v}) \\
1,6 \mathrm{M}\end{array}$ \\
\hline $\begin{array}{l}\text { Lysispuffer zur } \\
\text { Proteinisolierung aus } \\
\text { Zellkultur }\end{array}$ & $\begin{array}{l}\text { Tris-HCl, } \mathrm{pH} 7,5 \\
\mathrm{NaCl} \\
\mathrm{MgCl}_{2} \\
\text { Nonidet } \mathrm{P} 40\end{array}$ & $\begin{array}{l}50 \mathrm{mM} \\
150 \mathrm{mM} \\
5 \mathrm{mM} \\
0,2 \%(\mathrm{v} / \mathrm{v})\end{array}$ \\
\hline PBS inkomplett & $\begin{array}{l}\mathrm{NaCl} \\
\mathrm{Na}_{2} \mathrm{HPO}_{4} \\
\mathrm{KH}_{2} \mathrm{PO}_{4}\end{array}$ & $\begin{array}{l}180 \mathrm{mM} \\
8,5 \mathrm{mM} \\
2,2 \mathrm{mM}\end{array}$ \\
\hline $\begin{array}{l}\text { Polymerase-Master-Mix } \\
\text { für die endogene } \\
\text { Polymerasereaktion }\end{array}$ & $\begin{array}{l}\mathrm{MgCl}_{2} \\
\beta \text {-Mercaptoethanol } \\
\text { Nonidet P40 } \\
\text { dGTP, dATP, dTTP } \\
\alpha^{32} \mathrm{P}-\mathrm{dCTP}, 3000 \\
\mathrm{Ci} / \mathrm{mmol}\end{array}$ & $\begin{array}{l}20 \mathrm{mM} \\
0,1 \%(\mathrm{w} / \mathrm{v}) \\
0,5 \%(\mathrm{v} / \mathrm{v}) \\
\text { je } 0,4 \mathrm{mM} \\
0,06 \mu \mathrm{M}\end{array}$ \\
\hline $\begin{array}{l}\text { Polymerase-Puffer }(2 \mathrm{x}) \text {, } \\
\text { inkomplett }\end{array}$ & $\begin{array}{l}\text { Tris-HCl, pH 7,5 } \\
\mathrm{NH}_{4} \mathrm{Cl} \\
\text { Na-EDTA, pH 8,0 }\end{array}$ & $\begin{array}{l}100 \mathrm{mM} \\
155 \mathrm{mM} \\
2 \mathrm{mM}\end{array}$ \\
\hline $\begin{array}{l}\text { Probenauftragspuffer }(2 \mathrm{x}) \\
\text { für SDS-PAGE }\end{array}$ & $\begin{array}{l}\text { Tris-HCl, pH 6,8 } \\
\text { SDS } \\
\text { Glycerin } \\
\text { Bromphenolblau } \\
\text { DTT (frisch zugeben) }\end{array}$ & $\begin{array}{l}0,25 \mathrm{M} \\
12 \%(\mathrm{w} / \mathrm{v}) \\
20 \%(\mathrm{v} / \mathrm{v}) \\
0,06 \%(\mathrm{w} / \mathrm{v}) \\
10 \%(\mathrm{w} / \mathrm{v})\end{array}$ \\
\hline $\begin{array}{l}\text { Probenpuffer }(6 \mathrm{x}) \text { für } \\
\text { Agarosegelektrophorese }\end{array}$ & $\begin{array}{l}\text { TAE } \\
\text { Bromphenolblau } \\
\text { Xylencyanol } \\
\text { Glycerin }\end{array}$ & $\begin{array}{l}6 \mathrm{x} \\
0,04 \%(\mathrm{w} / \mathrm{v}) \\
0,04 \%(\mathrm{w} / \mathrm{v}) \\
30 \%(\mathrm{v} / \mathrm{v})\end{array}$ \\
\hline Proteinase K-Puffer $(2 \mathrm{x})$ & $\begin{array}{l}\text { SDS } \\
\text { Tris-HCl, pH 7,5 } \\
\text { Na-EDTA, pH 8,0 }\end{array}$ & $\begin{array}{l}2 \%(\mathrm{w} / \mathrm{v}) \\
20 \mathrm{mM} \\
20 \mathrm{mM}\end{array}$ \\
\hline
\end{tabular}




\begin{tabular}{|c|c|c|}
\hline $\begin{array}{l}\text { Sammelgelpuffer }(4 \mathrm{x}) \\
\text { für SDS-PAGE Gele }\end{array}$ & $\begin{array}{l}\text { Tris-HCl, } \mathrm{pH} 6,8 \\
\text { SDS }\end{array}$ & $\begin{array}{l}0,5 \mathrm{M} \\
0,4 \%(\mathrm{w} / \mathrm{v})\end{array}$ \\
\hline TAE $(50 \mathrm{x})$ & $\begin{array}{l}\text { Tris-Acetat, } \mathrm{pH} \mathrm{7,8} \\
\text { EDTA }\end{array}$ & $\begin{array}{l}2 \mathrm{M} \\
50 \mathrm{mM}\end{array}$ \\
\hline $\operatorname{TE}(50 x)$ & $\begin{array}{l}\text { Tris-HCl, pH 8,0 } \\
\text { Na-EDTA, pH 8,0 }\end{array}$ & $\begin{array}{l}0,5 \mathrm{M} \\
50 \mathrm{mM}\end{array}$ \\
\hline $\begin{array}{l}\text { Transfektionspuffer für } \\
\text { COS7-Zellen }\end{array}$ & $\begin{array}{l}\text { DEAE-Dextran } \\
\text { Chloroquin }\end{array}$ & $\begin{array}{l}10 \mathrm{mg} / \mathrm{ml} \\
2,5 \mathrm{mM}\end{array}$ \\
\hline $\begin{array}{l}\text { Transformationspuffer I } \\
\text { (TFB I) }\end{array}$ & $\begin{array}{l}\text { Kaliumacetat } \\
\text { Glycerin } \\
\mathrm{KCl} \\
\mathrm{CaCl}_{2} \\
\mathrm{MnCl}_{2}\end{array}$ & $\begin{array}{l}30 \mathrm{mM} \\
15 \%(\mathrm{w} / \mathrm{v}) \\
100 \mathrm{mM} \\
10 \mathrm{mM} \\
50 \mathrm{mM}, \mathrm{pH} 5,8 \mathrm{mit} \\
\text { Essigsäure einstellen }\end{array}$ \\
\hline $\begin{array}{l}\text { Transformationspuffer II } \\
\text { (TFB II) }\end{array}$ & $\begin{array}{l}\text { MOPS } \\
\mathrm{CaCl}_{2} \\
\mathrm{KCl} \\
\text { Glycerin }\end{array}$ & $\begin{array}{l}10 \mathrm{mM} \\
75 \mathrm{mM} \\
10 \mathrm{mM} \\
15 \%(\mathrm{v} / \mathrm{v})\end{array}$ \\
\hline $\begin{array}{l}\text { Trenngelpuffer }(4 \mathrm{x}) \\
\text { für SDS-PAGE Gele }\end{array}$ & $\begin{array}{l}\text { Tris-HCl, } \mathrm{pH} 8,8 \\
\text { SDS }\end{array}$ & $\begin{array}{l}1,5 \mathrm{mM} \\
0,1 \%(\mathrm{w} / \mathrm{v})\end{array}$ \\
\hline
\end{tabular}




\subsubsection{Zellkulturmedien und -platten}

\begin{tabular}{|l|l|l|}
\hline \multicolumn{2}{|l|}{ Zellkultur } \\
\hline $\begin{array}{l}\text { Dulbecco's Modified Eagle } \\
\text { Medium (DMEM) }\end{array}$ & Gibco BRL, Eggenstein & \\
\hline DMEM/Met/Cys- & ICN Biomedicals, Inc., Ohio & \\
\hline Fötales Kälberserum (FKS) & Seromed Biochrom KG & $10 \%$ (v/v) \\
\hline Antibiotikum-Antimykotikum & Gibco BRL, Eggenstein & $1 \%$ (v/v) \\
\hline $\begin{array}{l}\text { Gewekulturschalen, } \\
100 \text { mm x 20 mm }\end{array}$ & Corning/Dunn, Asbach & alle Zelllinien \\
\hline $\begin{array}{l}\text { Gewebekulturplatten, 6 well, } \\
\text { mit flachem Boden }\end{array}$ & Corning/Dunn, Asbach & zur Transfektion \\
\hline
\end{tabular}

\begin{tabular}{|c|c|c|}
\hline Bakterienkultur & & \\
\hline Luria Broth (LB) & $\begin{array}{l}\text { Bacto-Trypton } \\
\text { Bacto-Hefeextrakt } \\
\mathrm{NaCl}\end{array}$ & $\begin{array}{l}1 \%(\mathrm{w} / \mathrm{v}) \\
0,5 \%(\mathrm{w} / \mathrm{v}) \\
0,5 \%(\mathrm{w} / \mathrm{v})\end{array}$ \\
\hline $\begin{array}{l}\text { LB-Amp-Platten } \\
\text { (ca. } 15 \mathrm{ml} \text { pro } 10 \mathrm{~cm} \text { Schale) }\end{array}$ & $\begin{array}{l}\text { Bacto-Hefeextrakt } \\
\text { Bacto-Trypton } \\
\mathrm{NaCl} \\
\text { Agar (Difco, Detroit, USA) } \\
\text { Ampicillin (Na-Salz, } \\
\text { Boehringer, Mannheim) }\end{array}$ & $\begin{array}{l}0,5 \%(\mathrm{w} / \mathrm{v}) \\
0,1 \%(\mathrm{w} / \mathrm{v}) \\
1 \%(\mathrm{w} / \mathrm{v}) \\
1,5 \%(\mathrm{w} / \mathrm{v}) \\
100 \mu \mathrm{g} / \mathrm{ml}\end{array}$ \\
\hline Terrific Broth (TB) & $\begin{array}{l}\text { Bacto-Trypton } \\
\text { Bacto-Hefeetrakt } \\
\text { Glycerin }(87 \%) \\
\mathrm{K}_{2} \mathrm{HPO}_{4} \text { × } 3 \mathrm{H}_{2} \mathrm{O}\end{array}$ & $\begin{array}{l}1,2 \%(\mathrm{w} / \mathrm{v}) \\
2,4 \%(\mathrm{w} / \mathrm{v}) \\
0,4 \%(\mathrm{v} / \mathrm{v}) \\
70 \mathrm{mM}\end{array}$ \\
\hline TYM-Broth & $\begin{array}{l}\text { Bacto-Trypton } \\
\text { Bacto-Hefeextrakt } \\
\mathrm{NaCl} \\
\mathrm{MgCl}_{2}\end{array}$ & $\begin{array}{l}2 \%(\mathrm{w} / \mathrm{v}) \\
0,5 \%(\mathrm{w} / \mathrm{v}) \\
0,1 \mathrm{M} \\
0,01 \mathrm{M}\end{array}$ \\
\hline
\end{tabular}




\subsubsection{Materialien für Gelelektrophoresen}

peqGOLD Universal Agarose
peqLab, Biotechnologie GmbH, Erlangen

Die Agarose wurde vor der Verwendung als 0,7-2 \%ige (w/v) Lösung in $1 \times$ TAE aufgekocht.

\begin{tabular}{|l|l|}
\hline Acrylamid $(2 \mathrm{x})$ & Serva, Heidelberg \\
\hline Bisacrylamid $(2 \mathrm{x})$ & Serva, Heidelberg \\
\hline
\end{tabular}

Acrylamid für die Sequenzgelelektrophorese wurde als 40 \%ige (w/v) Stammlösung (38\% Acrylamid $/ 2 \%$ Bisacrylamid) angesetzt, mit einer Spatelspitze Amberlite (Sigma, Deisenhofen) für 30 min gerührt, sterilfiltriert und im Kühlschrank aufbewahrt. Acrylamid für die Proteingelelektrophorese wurde als 30,8 \%ige (w/v) Stammlösung (30\% Acrylamid/0,8 \%Bisacrylamid) angesetzt und im Kühlschrank aufbewahrt.

\subsubsection{Enzyme}

\begin{tabular}{|l|l|}
\hline Bal 31 Exonuklease & New England Biolabs, Schwalbach \\
\hline DNAseI & Boehringer, Mannheim \\
\hline Pfu-DNA-Polymerase & Stratagene GmbH, Heidelberg \\
\hline Proteinase K & Amresco, Ohio \\
\hline $\begin{array}{l}\text { Restriktionsendonukleasen mit } \\
\text { Puffern }\end{array}$ & New England Biolabs, Schwalbach \\
\hline RNAse A & Boehringer, Mannheim \\
\hline T4 DNA-Ligase & MBI Fermentas GmbH, St. Leon-Rot \\
\hline $\begin{array}{l}\text { Trypsin/EDTA-Lösung, }(10 \mathrm{x}) \\
0,5 / 0,2 \% \text { (w/v) in PBS ohne } \mathrm{Ca}^{2+} \text { und } \\
\mathrm{Mg}^{2+}\end{array}$ & \\
\hline
\end{tabular}




\subsubsection{Restriktionsendonukleasen}

\begin{tabular}{|c|c|}
\hline Restriktionsenzym & Erkennungssequenz und Spaltstellen \\
\hline EcoRI & $\begin{array}{l}5^{\prime} \ldots \text { G|AATTC } \ldots 3^{\prime} \\
3^{\prime} \ldots \text { CTTAA } \mid \text { G...5 }\end{array}$ \\
\hline EcoRV & $\begin{array}{l}5^{\prime} \ldots \text { GAT } \mid \text { ATC } \ldots 3^{\prime} \\
3^{\prime} \ldots \text { CTA|TAG....5' }\end{array}$ \\
\hline PstI & $\begin{array}{l}5^{\prime} \ldots \text { CTGCA } \mid \mathrm{G} \ldots .3^{\prime} \\
3^{\prime} \ldots \mathrm{G} \mid \text { ACGTC ...5' }\end{array}$ \\
\hline SpeI & $\begin{array}{l}5^{\prime} \ldots \text { A|CTAGT...3' } \\
3^{\prime} \ldots \text { TGATC } \mid \text { A....5' }\end{array}$ \\
\hline
\end{tabular}

\subsubsection{Oligonukleotide}

Folgende Oligonukleotide wurden für die PCR oder für die Sequenzierung eingesetzt.

\begin{tabular}{|l|l|}
\hline Primer & Sequenz $5^{\prime}$-> $3^{\prime}$ \\
\hline$\# 0237$ & TCTCGTGGTGGACTTC \\
\hline$\# 0238$ & TTCTCAATTTTCTAGGG \\
\hline$\# 0239$ & TGCAGTCCCCAACCTCC \\
\hline$\# 0240$ & TCAATCACTCACCAACC \\
\hline$\# 0241$ & TTCCTCCAATTTGTCC \\
\hline$\# 0242$ & TTCCTGGTTATCGCTGG \\
\hline$\# 0243$ & TTATCATATTCCTCTTC \\
\hline$\# 0244$ & GAAAATTGGTAACAGCGG \\
\hline$\# 0278$ & TCCAAAATTCGCAGTCCCC \\
\hline$\# 0279$ & TAACCTCCAATCACTCACC \\
\hline$\# 0280$ & TCTCACCAACCTCCTGTCC \\
\hline$\# 0281$ & TAACCTCCTGTCCTCCAATTTG \\
\hline$\#$ VB 5 & GGGGAAGCTTATGTCCACCAATCGGCAG \\
\hline
\end{tabular}




\subsubsection{Längenstandards für Gelelektrophoresen}

\begin{tabular}{|l|l|}
\hline $\begin{array}{l}\text { Proteinstandard Rainbow }{ }^{\mathrm{TM}}\left[{ }^{14} \mathrm{C}\right] \\
\text { (methylated protein molecular weight } \\
\text { marker), radioaktiv markiert }\end{array}$ & Amersham-Buchler, Braunschweig \\
\hline
\end{tabular}

\begin{tabular}{|l|l|}
\hline DNA-Längenstandards \\
\hline$\lambda$-DNA, BstEII-gespalten & New England Biolabs, Schwalbach \\
\hline Gene Ruler $^{\mathrm{TM}} 100$ bp DNA Ladder & MBI Fermentas GmbH, St. Leon-Rot \\
\hline
\end{tabular}

\subsubsection{Plasmide}

\begin{tabular}{|l|l|}
\hline Plasmidname & Beschreibung \\
\hline pSVBX24H ${ }^{[55]}$ & $\begin{array}{l}\text { Das Plasmid ist aus dem Vektor pSV65 (PERSING et al., } \\
\text { 1986) hervorgegangen. Es kodiert, nach Einfügen eines 1,9 } \\
\text { kb großen HBV-DNA-Fragments über die } \\
\text { Restriktionsschnittstellen PstI (nt 25) und BamHI (nt 1398), } \\
\text { für die Expression des kleinen HBV-Hüllproteins unter } \\
\text { Kontrolle des frühen SV40 Promotors. Die BamHI - } \\
\text { Schnittstelle bei Nukleotid 1398 in der HBV-Sequenz wurde } \\
\text { durch partiellen Verdau, Auffüllen der Enden durch Klenow- } \\
\text { DNA-Polymerase und einer nachfolgenden Ligation entfernt. }\end{array}$ \\
\hline pSVL $^{[68]}$ & $\begin{array}{l}\text { In den Vektor pBLUESCRIPT KS (+) (Stratagene, } \\
\text { Heidelberg) wurde hinter den SV40 Promotor aus dem } \\
\text { Plasmid pSV65 (PERSING et. al., 1986) das BstEII } \\
\text { (nt 2819)/ BspMII (nt 2327)-HBV-DNA-Fragment inseriert, } \\
\text { in dem dann die Startcodons für die M- und S- Gene in ACG } \\
\text { mutiert wurden. }\end{array}$ \\
\hline
\end{tabular}




\begin{tabular}{|l|l|}
\hline pSVHBV 1.5 $\mathrm{L}^{-}$ & $\begin{array}{l}\text { In den Vektor pSVHBV } 1.5 \text { wurde aus dem Plasmid } \\
\text { pRVHBV } 1.5 \mathrm{~L}^{-} \text {das BstEII/EcoRI-Fragment inseriert, in } \\
\text { dem ein Stopcodon in PräS1 erzeugt wurde, so daß das große } \\
\text { Hüllprotein nicht exprimiert werden kann. }\end{array}$ \\
\hline
\end{tabular}

\subsubsection{Escherichia-coli-Stamm}

\begin{tabular}{|l|l|}
\hline Bakterienstamm & Genotyp \\
\hline DH5 $\alpha^{[69]}$ & $\begin{array}{l}\text { supE44D, lacU 169 ( } \$ 80 \text { lacZDM15), hscR17, recA, endA1, } \\
\text { gyrA96, thi-1, rel A1 }\end{array}$ \\
\hline
\end{tabular}

\subsubsection{Antikörper}

\begin{tabular}{|l|l|l|}
\hline Antikörper & Spezifität & Hersteller \\
\hline gt anti-HBs & $\begin{array}{l}\text { Polyklonales Serum aus der Ziege, das } \\
\text { die Hüllproteine des HBV erkennt }\end{array}$ & DAKO, USA \\
\hline rb anti-HBc & $\begin{array}{l}\text { Polykonales Serum aus dem } \\
\text { Kaninchen, das HBcAg erkennt }\end{array}$ & DAKO, USA \\
\hline $\begin{array}{l}\text { ms antiLHBs } \\
\text { MA 18/7) }\end{array}$ & $\begin{array}{l}\text { Monoklonaler Antikörper aus der Maus } \\
\text { der spezifisch gegen das Epitop } \\
\text { Aminosäure 25-47 in der PräS1- } \\
\text { Domäne gerichtet ist }\end{array}$ & $\begin{array}{l}\text { Abt. Medizinische } \\
\text { Mikrobiologie, Göttingen }\end{array}$ \\
\hline
\end{tabular}




\subsubsection{Zelllinien}

\begin{tabular}{|l|l|}
\hline $\begin{array}{l}\text { COS7- } \\
\text { Zellen }^{[70]}\end{array}$ & $\begin{array}{l}\text { Durch Transformation mit Deletionsmutanten des Simian Virus } 40 \\
\text { (SV40) immortalisierte Affennierenzellen. Sie bilden konstitutiv das } \\
\text { große T- Antigen des Virus und replizieren deshalb mit hoher Effizienz } \\
\text { transfizierte Plasmide, die den SV40- origin enthalten. Diese Zelllinie ist } \\
\text { nur transient transfizierbar. }\end{array}$ \\
\hline $\begin{array}{l}\text { HuH7- } \\
\text { Zellen }^{[71]}\end{array}$ & $\begin{array}{l}\text { Humane Leberparenchymzellen eines primären Karzinoms, die sowohl } \\
\text { transient wie auch stabil mit der Kalziumphosphatmethode transfizierbar } \\
\text { sind. Nach Transfektion mit einem genomischen HBV-Konstrukt setzt } \\
\text { diese Zelllinie nackte Core-Partikel und Virionen frei. }\end{array}$ \\
\hline
\end{tabular}

\subsubsection{Geräte}

\begin{tabular}{|l|l|}
\hline ABI 373 A DNA-Sequenzer & Applied Biosystems Ltd., Weinheim \\
\hline $\begin{array}{l}\text { Autoradiographie } \\
\text { Film BIOMAX MR }\end{array}$ & Eastman Kodak Co, USA \\
\hline Brutschrank $\mathrm{CO}_{2}$-Auto-Zero & Heraeus, Hannover \\
\hline $\begin{array}{l}\text { Dialyseschläuche, } 16 \mathrm{~mm} \text { Durchmesser, } \\
\text { ca. } 10 \text { cm lang }\end{array}$ & Serva, Heidelberg \\
\hline Entwickler und Fixierbad & Cronex TD, Sigma, Deisenhofen \\
\hline Geltrockner & Biotec Fischer, Reiskirchen \\
\hline GeneAmp PCR System 960 und 9500 & Perkin Elmer \\
\hline $\begin{array}{l}\text { Laufkammer für } \\
\text { Agarosegelelektrophoresen }\end{array}$ & Eigenbau \\
\hline Magnetrührer & IKA, Schütt, Göttingen \\
\hline pH-Meter & Schott Geräte GmbH, Hofheim \\
\hline Refraktometer & Zeiss, Jena \\
\hline Schüttler Certomat U & B. Braun, Biotech, Melsungen \\
\hline Schwenker 3016 & GFL, Burgwedel \\
\hline $\begin{array}{l}\text { Sofortbildfotographie } \\
\text { Orangefilter Hoya G }\end{array}$ & Polaroid Corp., USA \\
\hline
\end{tabular}




\begin{tabular}{|l|l|}
\hline $\begin{array}{l}\text { Polaroidfilme Typ 665, 667 } \\
\text { Polaroid-Sofortbildkamera-System } \\
\text { Ultraviolett-Schirm Chroma } 41(254 \mathrm{~nm})\end{array}$ & $\begin{array}{l}\text { Polaroid Corp., USA } \\
\text { Polaroid Corp., USA } \\
\text { Eastman Kodak Co., USA }\end{array}$ \\
\hline Spektralphotometer DU 70 & Beckmann, München \\
\hline Vortexgerät & Bender\&Hobein AG, Schweiz \\
\hline $\begin{array}{l}\text { Waagen } \\
\text { Feinwaage handy }\end{array}$ & $\begin{array}{l}\text { Sartorius, Göttingen } \\
\text { Sartorius, Göttingen }\end{array}$ \\
\hline Wasserbad & GFL, Burgwedel \\
\hline Whatman Papier & Schleicher und Schuell, Dassel \\
\hline $\begin{array}{l}\text { Zentrifugen } \\
\text { Eppendorf Tischzentrifuge 5415 C } \\
\text { Kühlzentrifuge 5402 } \\
\text { Kühlzentrifuge RC-3B } \\
\text { Kühlzentrifuge 30 RF } \\
\text { Ultrazentrifuge L8-60M } \\
\text { Festwinkelrotor Ti 70.1 }\end{array}$ & $\begin{array}{l}\text { Eppendorf, Hamburg } \\
\text { Eppendorf, Hamburg } \\
\text { DuPont, Deutschland } \\
\text { Hettich, Tuttlingen } \\
\text { Beckman, München } \\
\text { Beckman, München }\end{array}$ \\
\hline
\end{tabular}

\subsubsection{Radioisotope}

Für Proteinanalysen (4.2.4.4) wurde ${ }^{35} \mathrm{~S}-$ Methionin/Cystein (Easy Tag Express ${ }^{35} \mathrm{~S}$-Protein labeling mix, NEG-772, $1000 \mathrm{Ci} / \mathrm{mmol}$ ) und für die endogene Polymerasereaktion (4.2.4.9) ${ }^{32} \mathrm{P}-$ Desoxycytosintriphosphat (alpha- ${ }^{32} \mathrm{P}-\mathrm{dCTP}$, NEG-013H, $3000 \mathrm{Ci} / \mathrm{mmol}$ ) von der Firma NEN, Bad Homburg, eingesetzt. 
4.2 Methoden

\subsubsection{Mikrobiologische Methoden}

\subsubsection{Anzucht des E. coli-Stammes DH5 $\alpha$}

Der Bakterienstamm DH5 $\alpha$ (4.1.9) wurde in sterilem LB- oder TB-Medium (4.1.2 ) bei $37^{\circ} \mathrm{C}$ unter Schütteln angezogen. Die Selektion plasmidtragender Stämme erfolgte über das Antibiotikum Ampicillin (Konzentration $100 \mu \mathrm{g} / \mathrm{ml}$ ).

\subsubsection{Herstellung kompetenter E. coli-Zellen ${ }^{[69]}$}

Die Fähigkeit von Bakterien zur Aufnahme freier DNA, ändert sich mit deren physiologischem Zustand. Während der exponentiellen Wachstumsphase der Zellen ist die Ausprägung am stärksten, sinkt danach aber schnell ab.

Eine Einzelkolonie des entsprechenden Bakterienstammes wurde für 2 Stunden in $5 \mathrm{ml}$ sterilem TYM-Broth (4.1.2) bei $37^{\circ} \mathrm{C}$ und $220 \mathrm{UpM}$ auf einem Schüttler inkubiert. Die gesamte Vorkultur wurde in $100 \mathrm{ml}$ TYM-Broth überimpft und die so erhaltene Hauptkultur unter denselben Bedingungen inkubiert, bis sie eine optische Dichte von 0,5 bei einer Wellenlänge von $500 \mathrm{~nm}$ aufwies. Zur Ernte wurde die Hauptkultur bei 3000 UpM und RT für 5 min zentrifugiert.

Das Bakterienpellet wurde in $40 \mathrm{ml}$ sterilem Transformationspuffer I (4.1.1) resuspendiert und für 30 min auf Eis inkubiert. Danach wurde die Bakteriensuspension erneut unter den oben beschriebenen Bedingungen zentrifugiert und das erhaltene Bakteriensediment in $4 \mathrm{ml}$ sterilem Transformationspuffer II (4.1.1) sanft resuspendiert. Die Bakteriensuspension wurde anschließen in Reaktionsgefäße (Eppendorf) portioniert, in flüssigem Stickstoff schockgefroren und bis zu ihrer Verwendung bei $-70^{\circ} \mathrm{C}$ aufbewahrt. 


\subsubsection{Transformation von E. coli-Zellen mit Plasmid-DNA ${ }^{[69]}$}

Als Transformation bezeichnet man die Übertragung von freier löslicher DNA in ein Bakterium. Hierzu müssen die Bakterien über eine entsprechende Kompetenz (4.2.1.2) verfügen.

Zur Transformation wurde der Bakterienstamm DH5 $\alpha$ als Rezipient für rekombinante DNA eingesetzt. Zunächst wurden schockgefrorene, kompetente Zellen auf Eis aufgetaut. Pro Transformationsansatz wurden $50 \mu$ l kompetente Zellen mit 10 ng DNA für 30 min auf Eis inkubiert. Anschließend erfolgte eine Inkubation für 1 min bei $42^{\circ} \mathrm{C}$. Nachdem der Ansatz 2 min auf Eis abgekühlt wurde, erfolgte die Zugabe von $250 \mu$ LB-Medium (4.1.2) und anschließende Inkubation für 1 Stunde bei $37^{\circ} \mathrm{C}$. Es wurden $0,2 \mathrm{ml}$ des Transformationsansatzes auf LB-Amp-Platten (4.1.2) ausplattiert und für $16 \mathrm{~h}$ bei $37^{\circ} \mathrm{C}$ inkubiert.

\subsubsection{Arbeiten mit DNA}

\subsubsection{Isolierung von DNA im analytischen Maßstab ${ }^{[72][73]}$}

1,5 ml einer TB-Amp-Übernachtkultur wurden für 2 min bei RT, $4000 \mathrm{UpM}$ sedimentiert, der Überstand verworfen und das Zellpellet in $100 \mu 1$ Lösung I (4.1.1) vollständig resuspendiert. Durch Zugabe von $200 \mu$ Lösung II (4.1.1) wurden die Bakterien unter vorsichtigem Invertieren des Reaktionsgefäßes vollständig lysiert. Nach 5 min Inkubation auf Eis wurde das Lysat mit $150 \mu$ Lösung III (4.1.1) versetzt, kurz geschüttelt und für weitere $5 \mathrm{~min}$ auf Eis inkubiert. Das Lysat wurde dann für $10 \mathrm{~min}$ bei $13000 \mathrm{UpM}$ zentrifugiert und der Überstand in ein neues Gefäß überführt. Die Nukleinsäure wurde mit Ethanol (4.2.2.5) präzipitiert und das Pellet in $50 \mu \mathrm{H}_{2} \mathrm{O}$ gelöst und bis zur weiteren Verwendung bei $-20^{\circ} \mathrm{C}$ aufbewahrt.

Plasmid-DNA mit hoher Reinheit wurde mit dem QIAGEN-Mini-DNA Kit hergestellt. Die Reinigung erfolgt dabei chromatographisch über kleine Säulen, die nach dem Prinzip des Anionenaustauschers funktionieren. Sie sind gefüllt mit einem modifizierten Silicagel, welches mit einer hydrophilen Substanz benetzt worden war, um unspezifische Bindungen 
zu verhindern. Die Präparation der Plasmid-DNA wurde wie von der Firma Qiagen angegeben durchgeführt.

\subsubsection{Isolierung der DNA im präparativen Maßstab ${ }^{[72][73]}$}

Um größere Mengen relativ reiner Plasmid-DNA zu erhalten, wurden $100 \mu 1$ einer transformierten E. coli-Bakterienvorkultur in $30 \mathrm{ml} \mathrm{TB}$-Amp-Medium (4.1.2) überimpft und für $12 \mathrm{~h}$ bei $37^{\circ} \mathrm{C}$ schüttelnd über Nacht inkubiert. Die Hauptkultur wurde in ein Falkonröhrchen überführt und die Bakterien bei 4000 UpM für 15 min sedimentiert. Der Überstand wurde verworfen und das Sediment in $5 \mathrm{ml}$ Lösung I (4.1.1) resuspendiert. Die Bakterien wurden anschließend durch $10 \mathrm{ml}$ Lösung II (4.1.1) unter vorsichtigem Invertieren des Gefäß alkalisch lysiert. Die Suspension wurde durch Zugabe von 7,5 ml Lösung III (4.1.1) neutralisiert, so daß nach kräftigem Schütteln die chromosomale DNA und Proteine ausfielen. Nach Zentrifugation für 5 min bei 4000 UpM wurde der Überstand in ein neues Falkonröhrchen überführt und mit Isopropanol gefällt (4.2.2.6). Der Überstand wurde verworfen und das Pellet in $3 \mathrm{ml}$ TE-Puffer (4.1.1) resuspendiert. Durch Zugabe von $3 \mathrm{ml}$ eiskalter Lösung IV (4.1.1) wurde die RNA gefällt und durch anschließende Zentrifugation bei 4000 UpM für 15 min sedimentiert. Die im Überstand befindliche DNA wurde nach Überführen in ein neues Falkonröhrchen erneut mit Isopropanol gefällt und durch Zentrifugation bei 4000 UpM für 10 min pelletiert. Das Sediment wurde in $3 \mathrm{ml}$ TEPuffer resuspendiert und die Plasmide anschließend durch PEG-Fällung (4.2.2.4) gereinigt.

\subsubsection{Phenol-Chloroform-Extraktion ${ }^{[72][73]}$}

Die Phenol-Chloroform-Extraktion wurde zum Entfernen von Proteinen aus Lösungen mit Nukleinsäuren eingesetzt.

Dazu wurde die DNA-haltige Lösung mit identischem Volumen Phenol/Chloroform/Isoamylalkohol (25:24:1) versetzt und gemischt. Zur Phasentrennung wurde die Probe 2 min bei $13000 \mathrm{UpM}$ zentrifugiert. Die wässrige Oberphase wurde abgenommen, mit Ethanol gefällt und anschließend in einer entsprechenden Menge TEPuffer aufgenommen. 


\subsubsection{PEG-Fällung ${ }^{[74]}$}

Zur Entfernung der restlichen RNA wurde das Pellet in $500 \mu$ TE/RNAse-Puffer aufgenommen und 30 min bei RT inkubiert. Die Fällung der DNA erfolgte durch Zugabe von $500 \mu$ PEG 6000-Lösung (4.1.1) für 30 min auf Eis. Die gefällte DNA wurde 10 min bei $4^{\circ} \mathrm{C}$ und $13000 \mathrm{UpM}$ sedimentiert und in $400 \mu$ TE-Puffer resuspendiert. Nach PhenolChloroform-Extraktion (4.2.2.3) und Ethanolfällung (4.2.2.5) wurde die DNA in $500 \mu 1$ TE-Puffer gelöst, die Konzentration bestimmt (4.2.2.7) und bei $-20^{\circ} \mathrm{C}$ aufbewahrt.

\subsubsection{Ethanolfällung ${ }^{[72][73]}$}

Für die Fällung wurde die DNA-haltige Lösung mit 0,1 Volumen Acetatpuffer (3 M) und dem doppelten Volumen Ethanol gemischt und 10 min auf Eis gestellt. Anschließend wurde bei $13000 \mathrm{UpM}$ und $4^{\circ} \mathrm{C}$ zentrifugiert. Die sedimentierte DNA wurde mit $70 \%$ igem Ethanol gewaschen, um mitgefällte Salze zu lösen. Nach Trocknung der DNA wurde diese in TE-Puffer aufgenommen.

\subsubsection{Isopropanolfällung ${ }^{[72][73]}$}

Die Isopropanolfällung ist eine salzfreie Fällungsreaktion. Dabei wurde durch Zugabe des 0,7-fachen Volumens Isopropanol die DNA für 10 min bei RT gefällt. Die anschließende Sedimentation erfolgt bei RT und 13000 UpM für $10 \mathrm{~min}$. Die pelletierte DNA wird in TEPuffer aufgenommen und bis zu ihrer weiteren Verwendung bei $-20^{\circ} \mathrm{C}$ aufbewahrt.

\subsubsection{Konzentrationsbestimmung von DNA und Proteinen}

Die Bestimmung der Konzentration von Nukleinsäuren ist zum einen durch die photometrische Analyse, zum anderen durch die Ethidiumbromid-Fluoreszenzabschätzung möglich. Die photometrische Analyse erfolgte im Spektralphotometer DU 70 (4.1.12) mit einer Quarzküvette. Zu jeder Messung wurde ein Referenzwert ermittelt (Messung des Lösungsmittels, in dem die Probe gelöst ist: TE-Puffer oder $\mathrm{H}_{2} \mathrm{O}$ ). Die Messung wurde bei 
einer Wellenlänge von $260 \mathrm{~nm}$ durchgeführt, weil das Absorptionsspektrum der Nukleotide AMP und UMP ein Maximum bei 260 nm besitzt. Bei allen Proben wurde zusätzlich die Extinktion bei einer Wellenlänge von $280 \mathrm{~nm}$ gemessen, dem Absorptionsmaximum der Aminosäure Tryptophan. Über den Quotient aus beiden Messungen (260 nm/280 nm) kann der Reinheitsgrad der Nukleinsäurelösung in bezug auf den Proteingehalt bestimmt werden. Im optimalen Fall sollte dieser Quotient bei 2 liegen.

Die Konzentration der Nukleinsäure errechnet sich nach folgender Formel:

$$
\begin{aligned}
\mathbf{c}= & \mathbf{E}_{260} \times \mathbf{f} \times \mathbf{K}(\mu \mathbf{g} / \mathbf{m l}) \\
\mathrm{c}= & \text { Konzentration } \\
\mathrm{E}= & \text { Extinktion (abzüglich des Referenzwertes }) \\
\mathrm{f}= & \text { Verdünnungsfaktor } \\
\mathrm{K}= & \text { Faktor: Die Konzentration, die in bei einer Schichtdicke von } \\
& 1 \mathrm{~cm} \text { einer } \mathrm{OD}_{260}=1 \text { entspricht. }
\end{aligned}
$$

Eine $\mathrm{OD}_{260}$ von 1 entspricht einer Konzentration von $50 \mu \mathrm{g} / \mathrm{ml}$ doppelsträngiger DNA,

$37 \mu \mathrm{g} / \mathrm{ml}$ einzelsträngiger DNA, $40 \mu \mathrm{g} / \mathrm{ml}$ einzelsträngiger RNA und $33 \mu \mathrm{g} / \mathrm{ml}$ Oligonukleotiden. Die angegebenen Zahlenwerte entsprechen somit dem Faktor K.

Bei der Ethidiumbromid-Fluoreszenzabschätzung wurde eine Nukleinsäurelösung neben Standardlösungen bekannter Konzentration ( $\lambda$-DNA) auf ein Agarosegel aufgetragen. Im Vergleich zum Standard wurde dann die Konzentration auf Grund der Fluoreszenzstärke abgeschätzt. Der Vorteil dieser Methode liegt darin, daß auch sehr geringe Mengen (bis ca.10 ng) nachgewiesen werden können.

\subsubsection{Agarosegelelektrophorese ${ }^{[74]}$}

Die Gelelektrophorese ermöglicht es, geladene Moleküle entsprechend ihrer Größe und Konformation aufzutrennen. Die „Laufstrecke“ von DNA-Fragmenten in einem elektrischen Feld entspricht ihrem Molekulargewicht und ihrer Konformation. Die Laufgeschwindigkeit der DNA-Fragmente ist abhängig von der angelegten Spannung, der Konzentration der Agarose im Gel und der Temperatur. DNA-Moleküle sind auf Grund ihrer Phosphatgruppen negativ geladen und wandern in einem elektrischen Feld in Richtung der Anode. Zur analytischen und präparativen Auftrennung von

DNA-Fragmenten wurden Agarose-Gelelektrophoresen in horizontalen Kammern eigener Bauart durchgeführt. Für analytische Zwecke wurden Gele mit 20-40 ml Volumen 
(Trennstrecke 7-8 cm) und für präparative Gele, wegen der größeren aufzutragenden Volumina, mit doppeltem Volumen und breiteren Taschen gegossen. Die AgaroseKonzentrationen variierten dabei zwischen 0,8 und $2 \%$ (w/v in TAE-Puffer). Die Anfärbung der Nukleinsäure im Agarose-Gel erfolgte durch Zugabe von $3 \mu 1$ Ethidiumbromid $(10 \mathrm{mg} / \mathrm{ml})$ zu etwa $30 \mathrm{ml}$ einer auf $60^{\circ} \mathrm{C}$ erwärmten Agarose-Lösung. Die DNA-Proben wurden vor dem Auftragen mit 1/5 Volumen 6 x Probenpuffer (4.1.1) gemischt. Dies diente zum Beschweren der Probe und zur Markierung der Lauffront. Als Elektrophoresepuffer diente 1 x TAE Puffer (4.1.1), in dem die mit den Proben beschickten Gele bei einer Spannung zwischen 90 und 120 V etwa 45 min bis zu 1.5 h belassen wurden. Dann wurden die DNA-Banden in den Gelen auf einem UV-Transilluminator (Chroma 41) bei $254 \mathrm{~nm}$ sichtbar gemacht und die Gele mit einer Polaroidkamera zur Dokumentation fotografiert.

\subsubsection{Spalten von DNA mittels Restriktionsendonukleasen ${ }^{[74]}$}

Restriktionsendonukleasen erkennen kurze DNA-Sequenzen und schneiden doppelsträngige DNA an bestimmten Stellen innerhalb oder außerhalb dieser Erkennungssequenzen. Meist handelt es sich hierbei um Palindromsequenzen. Die Erkennungssequenzen und Schnittstellen der verwendeten Restriktionsendonukleasen sind unter (4.1.5) aufgeführt. Die Behandlung von DNA mit Restriktionsendonukleasen ist eine häufige Methode in der Molekularbiologie, um z.B. Restriktionskarten von Plasmiden und Bakteriophagen herzustellen. Darüberhinaus werden sie eingesetzt, um genomische DNA zu fragmentieren und sie dann einer elektrophoretischen Trennung zu unterziehen. In dieser Arbeit wurden Restriktionsenzyme hauptsächlich dazu benutzt, definierte DNA-Fragmente zur Klonierung zu erhalten und zur Kontrolle und Charakterisierung von Plasmiden. Die Fähigkeit von Restriktionsenzymen zur DNA-Spaltung ist abhängig von der Temperatur sowie der Salzkonzentration im Reaktionsansatz. In Abhängigkeit vom jeweiligen Restriktionsenzym entstehen bei der Spaltung unterschiedliche Enden. Man unterscheidet zwischen stumpfen Enden (,,blunt-ends“) und komplementären einzelsträngigen Enden, die als kohäsive Enden (,sticky-ends“) bezeichnet werden.

Die Spaltung von DNA wurde in einem Gesamtvolumen von $20 \mu$ d durchgeführt. Der Reaktionsansatz bestand aus zu schneidender DNA, dem jeweiligen Restriktionsenzym und 1/10 Volumen des dazugehörigen $10 \times$ konzentrierten Puffers. Die Menge an 
einzusetzender Restriktionsendonuklease ist über die Einheit („Unit“ $\left.{ }^{“}=U\right)$ definiert. Das Volumen der Enzymlösung sollte 1/10 des Gesamtvolumens nicht überschreiten. Die Einheit U für ein Restriktionsenzym ist definiert als diejenige minimale Aktivität, die ausreicht, um in einer Stunde $1 \mu \mathrm{g} \lambda$-DNA vollständig in seine Fragmente zu zerlegen. Die Kontrolle der Restriktion erfolgte elektrophoretisch in Agarosegelen.

\subsubsection{Behandlung mit Exonuklease Bal31}

Bal31 ist eine Exonuklease, die 3'-und 5'-Enden von DNA abbaut. Da für die geplanten Experimente nur eine bestimmte Anzahl von Nukleotiden in einer statistischen Verteilung entfernt werden sollten, mußte die einzusetzende Enzymmenge und die weiteren Versuchsbedingungen vorher ausgetestet werden. Die Reaktionen wurden mit folgendem Ansatz bei $37^{\circ} \mathrm{C}$ durchgeführt:

\begin{tabular}{|l|l|}
\hline Reaktionsansatz & $5 \times$ Bal31-Puffer \\
\hline $5 \mu 1 \mathrm{DNA}(5 \mu \mathrm{g})$ & $3 \mathrm{M} \mathrm{NaCl}$ \\
$20 \mu \mathrm{l} 5 \times$ Bal31-Puffer & $60 \mathrm{mM} \mathrm{CaCl}_{2}$ \\
$1 \mu \mathrm{Bal} 31(0,1 \mathrm{U})$ & $60 \mathrm{mM} \mathrm{MgCl}_{2}$ \\
$74 \mu \mathrm{H}_{2} \mathrm{O}$ & $100 \mathrm{mM}$ Tris-HCl, $\mathrm{pH} 8,0$ \\
& $1 \mathrm{mM} \mathrm{Na}-\mathrm{EDTA}, \mathrm{pH} 8,0$ \\
\hline
\end{tabular}

Abhängig von der zu degradierenden Basenpaarzahl wurde zwischen 5 und 15 min inkubiert. Die Reaktion wurde durch Zugabe von $20 \mu \mathrm{l}$ Na-EGTA $(10 \mathrm{mM}, \mathrm{pH}$ 8,0), $80 \mu \mathrm{l}$ TE-Puffer und einer anschließenden Phenol-Chloroform-Extraktion (4.2.2.3) gestoppt. Nach Inkubation bei $65^{\circ} \mathrm{C}$ für 5 min und einer weiteren Phenol-Chloroform-Extraktion wurde die Nukleinsäure mit Ethanol präzipitiert (4.2.2.5). Um die Größe der Degradation zu überprüfen, wurde ein Aliquot auf ein 2 \%iges Agarosegel aufgetragen. 


\subsubsection{Behandlung mit Mung Bean-Nuklease}

Mungbean-Nuklease ist ein Enzym, das in der Lage ist einzelsträngige DNA abzubauen.

Die Aktivität dieses Enzyms wurde ausgenutzt um beispielsweise nach Schneiden mit einem Restriktionsenzym das überstehende 3'- oder 5'-Enden zu entfernen und stumpfe Enden für eine anschließende Ligation zu erhalten.

Zuerst wurde die DNA mit einem Restriktionsenzym vollständig geschnitten. Anschließend wurde sie mit Ethanol gefällt (4.2.2.5), in einem entsprechenden Volumen $\mathrm{H}_{2} \mathrm{O}$ resuspendiert und mit Mungbean-Nuklease zur Reaktion gebracht.

Die Reaktion wurde in folgendem Ansatz durchgeführt und 30 min bei $30^{\circ} \mathrm{C}$ inkubiert:

\begin{tabular}{|l|l|}
\hline Reaktionsansatz & $10 \times$ Mung Bean-Puffer \\
\hline $20 \mu \mathrm{l}$ DA & $50 \mathrm{mM} \mathrm{NaAc}, \mathrm{pH} 5.0$ \\
$3 \mu 110 \times$ Mung Bean-Puffer & $300 \mathrm{mM} \mathrm{NaCl}$ \\
$1 \mu \mathrm{l} 1 \mathrm{U}$ Mung Bean-Nuklease & $10 \mathrm{mM} \mathrm{ZnSO}_{4}$ \\
$6 \mu 1 \mathrm{H}_{2} \mathrm{O}$ & \\
\hline
\end{tabular}

Die Inaktivierung des Enzyms erfolgte durch anschließende Phenol-Chloroform-Extraktion (4.2.2.3).

\subsubsection{DNA-Extraktion aus Agarosegelen}

Die Auftrennung von DNA-Fragmenten im Agarosegel wurde genutzt, um DNA mit spezifischer Länge im präparativen Ansatz $\mathrm{zu}$ isolieren. Nach Spaltung mit Restriktionsendonukleasen (4.2.2.9) wurde das gewünschte Fragment bei möglichst kurzer Beleuchtung mit UV-Licht mit einem Skalpell exakt aus dem Gel ausgeschnitten. Anschließend wurde die DNA aus der Gelmatrix unter Verwendung des „QIAquick Gel Extraction kit“" (QIAGEN, Hilden) nach dem Protokoll des Herstellers extrahiert. 


\subsubsection{Ligation ${ }^{[74]}$}

Die T4-DNA-Ligase katalysiert unter Hydrolyse von ATP die Verknüpfung von 3' OH- und 5'Phosphat-Enden über eine Phosphodiesterbindung und ist so in der Lage, Fremd-DNA in ein Plasmid zu integrieren. Bei der Ligation wird unterschieden zwischen „blunt-end“ und „,sticky-end“-Ligationen. Die Effizienz der T4-DNA-Ligase ist bei der „,blunt-end“-Ligation wesentlich geringer als bei der „sticky-end“-Ligation, daher erfordert die „blunt-end“Ligation eine längere Reaktionszeit und den Einsatz von ca. der 10-fachen Menge an T4DNA-Ligase.

Ist die Linearisierung des Vektors und die Präparation des einzusetzendes Fragments (Insert) mit dem Restriktionsenzym erfolgt, welches „sticky-ends“ hervorbringt, so besitzen die Enden der Fragmente eine spezifische Affinität zueinander und können ohne Vorbehandlung in den Vektor ligiert werden. Zu inserierende Fragmente, die mittels PCR (4.2.2.13) erhalten wurden, wurden mit Pfu-Polymerase (4.1.4) amplifiziert, die „,bluntends" erzeugt.

Das Verhältnis von einzubringender DNA (Insert) und Vektor-DNA beeinflußt den Erfolg der Ligation und kann nach folgender Formel ermittelt werden.:

$$
\begin{aligned}
\mathbf{z} & =\mathbf{V} \times \mathbf{y} \times \mathbf{I n s e r t}(\mathbf{k b}) / \text { Vektor }(\mathbf{k B}) \\
\mathrm{z} & =\text { einzusetzende Insertmenge in } \mathrm{ng} \\
\mathrm{y} & =\text { die Menge an Vektor-DNA in ng } \\
\mathrm{V} & =\text { Verhältnis von Insert zu Vektor (z.B. 1:1, 3:1 oder10:1) }
\end{aligned}
$$

Die Ligation wurde in einem Gesamtvolumen von $10 \mu l$ durchgeführt. Die Mengenverhältnisse von Vektor und Insert wurden nach der oben genannten Formel ermittelt. Es wurden in der Regel ca. 20 ng Vektor eingesetzt. Die Reaktionsansätze wurden anschließend für die Transformation (4.2.1.3) eingesetzt. Die Orientierung der eingefügten Fremd-DNA im Plasmid wurde durch das Bestimmen eines Restriktionsmusters (4.2.2.9) überprüft. Ein positives Plasmid wurde daraufhin sequenziert (4.2.2.15)

\subsubsection{Polymerase-Kettenreaktion (polymerase chain reaction, $\mathrm{PCR})^{[75]}$}

Die Polymerase-Kettenreaktion ist eine schnelle und sensitive Methode, um in vitro ein bestimmtes DNA-Fragment enzymatisch zu amplifizieren. Im Reaktionsansatz müssen die zu amplifizierende doppelsträngige DNA, zwei einzelsträngige Oligonukleotid-Primer 
(sense und antisense) sowie alle vier Desoxyribonukleosid-Triphosphate (dNTPs) vorhanden sein. Weiterhin befindet sich noch als Enzym die thermostabile DNAPolymerase im Reaktionsansatz. Im Falle dieser Arbeit wurde Pfu-Polymerase zur Amplifikation von Fragmenten mit „blunt-ends“ verwendet. Die Primerkonzentration ist dabei um ein Vielfaches höher als die der $\mathrm{zu}$ amplifizierenden DNA. Die Primer hybridisieren jeweils am gegenüberliegenden DNA-Strang, und ihre 3'-Enden zeigen zueinander. Der Vervielfältigungsprozeß unterliegt drei aufeinander folgenden Temperaturschritten, die in einem progammierbaren Thermocycler (4.1.12) ablaufen. Der erste Schritt bewirkt die Denaturierung des Doppelstranges in beide Einzelstränge, so daß sich in Schritt zwei, dem „Annealing“, die Primer an die Einzelstränge anlagern können und mittels der Polymerase der letzte Schritt, die Vervollständigung des Einzelstranges in 5'-> 3'-Richtung komplementär zum Matrizenstrang, vollzogen wird (Elongation). Es entstehen so zwei Doppelstränge aus zwei Einzelsträngen.

Die PCR wurde gemäß folgender Tabelle durchgeführt.

\begin{tabular}{|l|l|}
\hline PCR-Puffer $(10 \mathrm{x})$ & $10 \mu \mathrm{l}$ \\
\hline $\begin{array}{l}\text { Nukleotide (dATP, dCTP, dGTP, } \\
\text { dTTP })\end{array}$ & je $250 \mu \mathrm{M}$ \\
\hline Primer & je 20 pmol \\
\hline Pfu-DNA-Polymerase & $0,5 \mathrm{U}$ \\
\hline DNA & $10-100 \mathrm{ng}$ \\
\hline $\mathrm{H}_{2} \mathrm{O}$ & ad $100 \mu \mathrm{l}$ \\
\hline
\end{tabular}

Die Reaktionskomponenten wurden mit Ausnahme der Template-DNA für alle Ansätze als Gemisch angesetzt und dann auf die Reaktionsgefäße verteilt. Die zyklischen Temperaturprogramme wurden entsprechend der Oligonukleotidkombination variiert. Die Annealingtemperatur wurde entsprechend dem Primer mit der niedrigsten Schmelztemperatur gewählt, das Zeitintervall für die Fragmentverlängerung richtete sich nach der Länge des zu erwartenden Produkts. Pro 1000 Nukleotiden Fragmentlänge wurden 60 sek für den Elongationsschritt gewählt.

Die PCR zur Vervielfältigung von HBV-DNA wurde in einem Thermocycler (TC 9600 Perkin Elmer) mit folgendem Temperaturprogramm durchgeführt. 


\begin{tabular}{|l|l}
\hline 30 sek $96^{\circ} \mathrm{C}$ & 35 Zyklen \\
20 sek $45-60^{\circ} \mathrm{C}$ & \\
60 sek (pro $1000 \mathrm{Bp}), 72^{\circ} \mathrm{C}$ & \\
\hline
\end{tabular}

\subsubsection{Aufreinigung von PCR-Produkten}

Wenn durch die PCR ein einzelnes Produkt amplifiziert wurde, konnte dieses ohne präparative Gelelektrophorese aufgereinigt werden. Für Reaktionen mit Restriktionsenzymen mußte das DNA-Fragment von eventuell störenden Reaktionskomponenten der PCR getrennt werden. Dieses geschah unter Verwendung des „QIAquick PCR Purification Kit“ der Firma Qiagen (Hilden). Die Durchführung folgte dem Protokoll des Herstellers. Das DNA-Fragment wurde mit $50 \mu$ TE-Puffer von der Säule eluiert.

\subsubsection{Sequenzierung von DNA ${ }^{[76]}$}

Die Sequenzierung erfolgte durch die Methode nach Sanger. Sequenziert wird dabei nur ein Strang der DNA. Entsprechend wird nur ein Oligonukleotid-Primer in die Sequenzierreaktion eingesetzt, welcher sich an einen Strang der DNA anlagert zu dem er komplementär ist. Anschließend werden dann durch eine DNA-Polymerase Desoxyribonukleotide (dNTP) an das freie 5'Phosphat-Ende des Primers addiert. Somit wächst die Kette, die jedoch durch gleichzeitige Anwesenheit einer kleinen Menge Didesoxyribonukleotid (ddNTP), denen das 3'OH fehlt, regelmäßig abgebrochen wird. Anstelle des $3^{\prime} \mathrm{OH}$ tragen die ddNTP vier unterschiedliche RhodaminFluoreszenzfarbmarkierungen. (dyeddNTP). (Tab. 4.1) 


\begin{tabular}{|l|l|l|}
\hline & Bezeichnung & $\begin{array}{l}\text { Absorptions-/ } \\
\text { Emmissions- } \\
\text { Max. }\end{array}$ \\
\hline Didesoxy-A & ${\mathrm{N}, \mathrm{N}^{\prime} \text {-diethyl-2',7'-dimethyl-6-carboxyrhodamin }}$ & $520 / 545 \mathrm{~nm}$ \\
\hline Didesoxy-C & 6-carboxy-rhodamin & $585 / 605 \mathrm{~nm}$ \\
\hline Didesoxy-G & 6-carboxyrhodamin 110 & $500 / 530 \mathrm{~nm}$ \\
\hline Didesoxy-T & $\begin{array}{l}\text { N,N,N',N'-tetramethyl-2',7'-dimethyl-6- } \\
\text { carboxyrhodamin }\end{array}$ & $555 / 580 \mathrm{~nm}$ \\
\hline
\end{tabular}

Tab. 4.1: Didesoxyribonukleotide (ddNTP) und die entsprechenden RhodaminFluoreszensfarbmarkierungen

Der Einbau der dyeddNTP und der damit verbundene Kettenabbruch geschehen zufällig. Im Laufe der Reaktion entsteht eine Serie von Ketten mit den unterschiedlichsten Längen. Die Auftrennung der so entstandenen farbstoffmarkierten Ketten erfolgt in einem denaturierenden 6 \%igen Polyacrylamidgel. Die Detektion geschieht dabei mit einem Argonlaser und einem Photomultiplier.

Die Sequenzierungsreaktion wurde gemäß den Angaben des Herstellers durchgeführt.

\begin{tabular}{|l|l|}
\hline DNA & $600-1000 \mathrm{ng}$ \\
\hline Oligonukleotid & 5 pmol \\
\hline Sequenziermix (Puffer, dNTP, dyeddNTP, Polymerase) & $6 \mu 1$ \\
\hline $\mathrm{H}_{2} \mathrm{O}$ & $\mathrm{ad} 17 \mu \mathrm{l}$ \\
\hline
\end{tabular}

Die Sequenzierreaktion wurde in einem PCR-Gerät (TC 9600 Perkin Elmer) mit folgendem Temperaturprogramm durchgeführt.

\begin{tabular}{|l|l|}
\hline 30 sek $96^{\circ} \mathrm{C}$ & 25 Zyklen \\
20 sek $45-60^{\circ} \mathrm{C}$ (je nach Primer) & \\
$4 \min 60^{\circ} \mathrm{C}$ & \\
\hline
\end{tabular}


Nach der Sequenzierreaktion wurden $50 \mu$ Ethanol und $2 \mu 1$ Natriumacetatpuffer $(3 \mathrm{M}, \mathrm{pH}$ 4,7) zur Fällung der Fragmente zugegeben, die Probe gemischt und 10 min auf Eis gekühlt. Die Sedimentation erfolgte bei $4^{\circ} \mathrm{C}$ und 13000 UpM. Das Pellet wurde mit $100 \mu 170 \%$-igem Ethanol gewaschen, getrocknet und in $4 \mu 1$ Formamid-EDTA-Puffer gelöst. Vor dem Auftragen mußten die Proben noch denaturiert werden. Hierzu wurden sie für 2 min auf $96^{\circ} \mathrm{C}$ erhitzt, wodurch die doppelsträngige DNA aufgeschmolzen und einzelsträngige DNA erhalten wurde. Um eine erneute Zusammenlagerung der Einzelstränge zu verhindern, wurden die Proben anschließend auf Eis gelagert. Zudem verhindert die Anwesenheit von Formamid nach der Denaturierung ein erneutes Hybridisieren. Nun konnten die so erhaltenen Einzelstränge nach ihrer Größe aufgetrennt und analysiert werden. Die Auswertung der Rohdaten erfolgte automatisch mit der Software des Gerätes.

\subsubsection{Arbeiten mit Zellkultur}

Sämtliche Arbeiten mit Zellkulturen wurden unter einer Sterilbank durchgeführt. Zum Umsetzen, Transfizieren und Waschen der Zellen wurden stets auf $37^{\circ} \mathrm{C}$ erwämte Lösungen verwendet. Die Inkubation der Zellen erfolgte im Brutschrank bei $37^{\circ} \mathrm{C}$ und $5 \% \mathrm{CO}_{2}$ Atmosphäre. Als Kulturmedium wurde DMEM mit 10\% (v/v) FKS (4.1.2) und Antibiotikum-Antimykotikum (4.1.2) verwendet.

\subsubsection{Subkultivierung von Zellen}

Die Zellen wurden zur Erhaltung alle 2-3 Tage umgesetzt. Hierzu wurden die adhärent wachsenden Zellen mit $10 \mathrm{ml}$ PBS gewaschen, mit $3 \mathrm{ml}$ Trypsin/EDTA (4.1.4) in PBS abgelöst und nach kurzer Inkubation bei $37^{\circ} \mathrm{C}$ im Brutschrank in $8 \mathrm{ml}$ Medium aufgenommen und durch Auf- und Abpipettieren vereinzelt. Danach wurden sie um den Faktor 4-6 verdünnt in frischem Medium ausgesät und bis zur weiteren Verwendung bei $37^{\circ} \mathrm{C}$ unter $5 \% \mathrm{CO}_{2}$-Luftgemisch gehalten. 


\subsubsection{Transiente Transfektion eukaryontischer Zellen}

Zwölf Stunden vor der Transfektion wurden die Zellen subkultiviert (4.2.3.1). Die Zelldichte sollte am Tag der Transfektion ca. $60 \%$ erreicht haben.

Die folgenden Angaben beziehen sich auf Gewebekulturschalen mit $2 \mathrm{~cm}$ Durchmesser.

Bei Verwendung anderer Kulturschalen mußten die eingesetzten Volumina entsprechend abgeändert werden. Vor der Transfektion wurden die Zellen mit PBS gewaschen.

\subsubsection{Transfektion von COS7-Zellen mit DEAE-Dextran}

Zwei $\mu \mathrm{g}$ der zu transfizierenden DNA wurden mit $40 \mu$ DEAE-Dextran/Chloroquin (4.1.1) und $2 \mathrm{ml} \mathrm{DMEM/FKS} \mathrm{gut} \mathrm{vermischt} \mathrm{und} \mathrm{auf} \mathrm{die} \mathrm{gewaschenen} \mathrm{Zellen} \mathrm{gegeben.} \mathrm{Nach} \mathrm{ca.} 4$ h Inkubation bei $37^{\circ} \mathrm{C}$ im Brutschrank wurde das Transfektionsmedium entfernt und die Zellen mit einer 10\%igen DMSO-Lösung in PBS versetzt. Nach 2 min wurde diese Lösung entfernt, die Zellen mit PBS gewaschen, neues Kulturmedium zugegeben und für einen weiteren Tag im Brutschrank inkubiert.

\subsubsection{Transfektion von HuH7-Zellen mittels Kalziumphosphat}

Durch diese Methode wird sowohl der transiente wie auch der stabile Gentransfer in eukaryontische Zellen ermöglicht. Mittels dieser Methode werden DNA-KalziumphosphatPräzipitate hergestellt, die von den Zellen in einem Phagozytose-Prozeß aufgenommen werden.

Zur Herstellung dieser Präzipitate wurden $2 \mu \mathrm{g}$ Plasmid-DNA mit $100 \mu 1250 \mathrm{mM} \mathrm{CaCl} 2$ vermischt, tropfenweise zu $100 \mu 12 \times$ HBS-Lösung (4.1.1) gegeben und $30 \mathrm{~min}$ bei RT inkubiert. Dieses Gemisch wurde auf die mit $2 \mathrm{ml}$ frischem Medium versehenen Zellen getropft und $6-8 \mathrm{~h}$ bei $37^{\circ} \mathrm{C}$ im Brutschrank inkubiert. Anschließend wurde das Transfektionsmedium entfernt, die Zellen mit PBS gewaschen und frisches Medium hinzugegeben. Die Zellen wurden dann für mindestens vier weitere Tage im Brutschrank inkubiert. 


\subsubsection{Bestimmung des HBsAg-Titers}

Die Bestimmung des HBsAg-Titers im Überstand transfizierter eukaryontischer Zellen wurde freundlicherweise in der Diagnostikabteilung der Abteilung Virologie durchgeführt (HBsAg-Test der Firma Sorin Biomedica, Saluggia, Italien).

Für den ELISA wurden ca. $10 \mu \mathrm{l}$ des Zellüberstandes 2 - 4 Tage nach der Transfektion abgenommen und 1:50 in PBS verdünnt in den Test eingesetzt. Die Transfektion war erfolgreich, wenn die Zellen, die zuvor mit einem entsprechenden Plasmid transfiziert worden waren, eine HBsAg-Konzentration von etwa $20 \mathrm{ng} / \mathrm{ml}$ in den Überstand sezerniert hatten.

\subsubsection{Proteinchemische Arbeiten}

\subsubsection{Ernte und Aufreinigung des Zellkulturmediums}

Zum Nachweis der in das Zellmedium sekretierten Hüllproteine bzw. kompletten Virionen wurde das Medium 2 - 5 Tage nach der Transfektion abgenommen und durch Zentrifugation (5 min, $13000 \mathrm{UpM}$ ) geklärt. Anschließend wurde es in ein neues Röhrchen überführt und bis zur weiteren Untersuchung bei $4^{\circ} \mathrm{C}$ gelagert.

\subsubsection{Herstellung von Zelllysaten}

Nach Abnahme des Zellkulturüberstands wurden die Zellen zunächst mit $1 \mathrm{ml}$ PBS gewaschen, um extrazellulär anhaftendes Material zu entfernen. Die Lyse der Zellen geschah durch Detergenzbehandlung. Es wurde je $1 \mathrm{ml}$ Zellysispuffer (4.1.1) pro $20 \mathrm{~mm}$ Schale verwendet. Der Zellrasen wurde durch 10-minütiges Schwenken und anschließendes Auf- und Abpippettieren vom Schalenboden abgelöst. Danach wurde es einem Zentrifugationsschritt (5 min, $13000 \mathrm{UpM}$ ) unterworfen und der Überstand in ein neues Reaktionsgefäß überführt, wo er bis zur weiteren Verwendung bei $-20^{\circ} \mathrm{C}$ gelagert werden konnte. 


\subsubsection{Immunpräzipitation}

Die Immunpräzipitation ermöglicht eine rasche und effektive Isolierung von Antigen aus Zellkulturüberständen (4.2.4.1) und Zellysaten (4.2.4.2) von transfizierten Zellen über den Einsatz spezifischer Antikörper (4.1.10), die an Protein A/Sepharose (Sigma, Deisenhofen) gebunden sind. Zunächst wurden pro Ansatz 2,5 mg Protein A/Sepharose quellen gelassen, dann dreimal mit PBS gewaschen (gemischt, 30 sek bei 13000 UpM zentrifugiert). Nach der Quellung entsprach dies $10 \mu \mathrm{l} \mathrm{Gel.}$

Die Bindung der Antikörper an Protein A/Sepharose geschah nach Zugabe von $1 \mu 1$ Antikörperlösung $(1 \mathrm{mg} / \mathrm{ml})$ pro $10 \mu \mathrm{l} \mathrm{Gel} \mathrm{durch} \mathrm{anschließende} \mathrm{Inkubation} \mathrm{von} 4 \mathrm{~h}$ bei RT oder über Nacht bei $4^{\circ} \mathrm{C}$ im vertikal rotierenden Probenrotor. Der Komplex aus Protein $\mathrm{A} /$ Sepharose und Antkörper wurde $\mathrm{zu}$ der Antigenlösung gegeben und zur Immunpräzipitation $4 \mathrm{~h}$ bei RT oder über Nacht bei $4^{\circ} \mathrm{C}$ im Probenrotor inkubiert.

\subsubsection{Radioaktive metabolische Markierung von Zellen (pulse/chase)}

Zur Untersuchung von geringen Mengen der in Zellkultur exprimierten Proteine in Zellen wurden diese radioaktiv markiert. Im Gegensatz zu Bakterien und Hefen können die Säugetierzellen Methionin und Cystein nicht „de novo“ synthetisieren. Dem entsprechend kann zur metabolischen Markierung von Proteinen von außen ins Medium zugesetztes ${ }^{35} \mathrm{~S}-$ Methionin oder/und -Cystein benutzt werden. Um die Markierung zu verstärken, wurden die Zellen zuvor in einem Medium, dem die entsprechenden Aminosäuren fehlten, inkubiert. 24 Stunden nach der Transfektion (4.2.3.2) wurden die Zellen mit steriler PBSLösung gewaschen, pro bewachsener Gewebekulturschale 0,6 ml DMEM/Met" $/ \mathrm{Cys}^{-}$ zugegeben und für $40 \mathrm{~min}$ bei $37^{\circ} \mathrm{C}$ inkubiert. Danach erfolgte die Markierung (pulse) durch Zugabe von $88 \mu \mathrm{Ci}{ }^{35} \mathrm{~S}$-Methionin/Cystein pro Schale über einen Zeitraum von 30 min bei $37^{\circ} \mathrm{C}$. Danach wurde der radioaktive Zellüberstand abpipettiert und durch $1 \mathrm{ml}$ DMEM-Medium ersetzt. Bis zur Zelllyse (4.2.4.2) und einer anschließenden Immunpräzipitation (4.2.4.3) erfolgte eine Inkubation (chase) der Zellen für $24 \mathrm{~h}$ bei $37^{\circ} \mathrm{C}$ unter $5 \% \mathrm{CO}_{2}$-Luftgemisch. 


\subsubsection{Herstellung von SDS-Polyacrylamidgelen}

Zur Größenbestimmung und Analyse wurden radioaktiv markierte Proteine (4.2.4.4) in SDS-Polyacrylamidgelen im diskontinuierlichen Puffersystem aufgetrennt.

Die Auftrennung erfolgte in einem Sammel- und einem Trenngel. An der Grenze von Sammel- und Trenngel wurden die Proteine zu einer schmalen Bande komprimiert, um dann im Trenngel nach Größe aufgetrennt zu werden. Für die Gelelektrophorese wurden sogenannte „Studier“-Gele verwendet. Es wurden jeweils 2 Glasplatten zusammengesetzt, zum Abdichten der Abstandshalter (spacer) wurde Vaseline verwendet. Anschließend wurde das Trenngel zwischen die beiden Glasplatten bis ca. $1 \mathrm{~cm}$ unterhalb des Kammes gegossen und zum Abschluß vor Luftsauerstoff mit $20 \%(\mathrm{v} / \mathrm{v})$ Methanol überschichtet. Nach Auspolymerisieren des Trenngels wurde das Methanol abgegossen, das Sammelgel auf das Trenngel gegossen und der Kamm in die polymerisierende Lösung geschoben. Die Zusammensetzung der Gele entspricht der folgenden Tabelle (Tab. 4.2).

\begin{tabular}{|l|l|l|}
\hline & $5 \%$ Sammelgel & $13 \%$ Trenngel \\
\hline Acrylamid-Monomerlösung & $1,6 \mathrm{ml}$ & $10,3 \mathrm{ml}$ \\
\hline $\begin{array}{l}4 \times \text { Sammelgelpuffer } \\
(4.1 .1)\end{array}$ & $3 \mathrm{ml}$ & - \\
\hline $4 \times$ Trenngelpuffer $(4.1 .1)$ & - & $7,5 \mathrm{ml}$ \\
\hline $\mathrm{H}_{2} \mathrm{O}$ & $7,4 \mathrm{ml}$ & $12 \mathrm{ml}$ \\
\hline $10 \%(w / v)$ APS & $80 \mu \mathrm{l}$ & $200 \mu \mathrm{l}$ \\
\hline TEMED & $20 \mu \mathrm{l}$ & $50 \mu \mathrm{l}$ \\
\hline
\end{tabular}

Tab 4.2: Zusammensetzung eines SDS-PAGE-Geles

\subsubsection{SDS-Polyacrylamidgelelektrophorese (SDS-PAGE) ${ }^{[77]}$}

Vor Durchführung der Elektrophoresen wurden der untere spacer und Reste des Vakuumfettes entfernt. Das Gel wurde in die Elektrophoresekammer $(185 \mathrm{~mm} \times 275 \mathrm{~mm}$, Eigenbau Abt. Med. Mikrobiologie) eingespannt, diese mit SDS-Laufpuffer (4.1.1) befüllt und der Kamm entfernt. Die Taschen wurden zum Entfernen von Polyacrylamidresten mit 
einer Pipette ausgespült. Vor dem Auftragen der Proben wurden diese mit dem gleichen Volumen 2 x Probenpuffer (4.1.1) gemischt und für 5 min auf $95^{\circ} \mathrm{C}$ erhitzt, um die Proteine $\mathrm{zu}$ denaturieren und die Disulfidbrücken zu spalten. Die Auftrennung erfolgte bei einer Stromstärke von 5-20 mA.

\subsubsection{Coomassiefärbung}

Nach Beendigung der Elektrophorese wurden die Proteine durch Schwenken des Gels bei RT für 30 min in Coomassie-Blau-Lösung (4.1.1) gefärbt und anschließend Farbrückstände durch Schwenken für 45 min bei RT in einem Entfärbe-Bad (4.1.1) herausgewaschen. Danach wurde das Gel in Amplify-Lösung für weitere 15 min geschwenkt, auf WhatmanPapier überführt und unter Vakuum bei $80^{\circ} \mathrm{C}$ getrocknet.

\subsubsection{Autoradiographie}

Der Nachweis von radioaktiv markierten Proteinen erfolgte durch Exposition der getrockneten Gele auf Röntgenfilmen (Biomax, Sigma, Deisenhofen) bei $-70^{\circ} \mathrm{C}$ für 2 - 14 Tage.

Die Entwicklung des Films erfolgte durch Eintauchen für 2 min in ein Entwicklerbad (4.1.12). Der Film wurde anschließend kurz in 5 \%ige Essigsäure, eingetaucht um den Entwicklungsvorgang abzustoppen, und zur Fixierung für 4 min in ein Fixierbad (4.1.12) getaucht. Der Film wurde bei RT gewässert und luftgetrocknet.

\subsubsection{Endogene Polymerasereaktion (EPR)}

Die endogene Polymerasereaktion (EPR) ist ein Testsystem, mit dem die Aktivität der viralen Polymerase des HBV untersucht werden kann. Der Test dient als Nachweis von mit anti-HBc immunpräzipitierten Hepatitis B Nukleokapsiden aus Zellysaten und kompletten Virionen, die aus dem Zellkulturüberstand mit anti-HBs immunpräzipitiert wurden.

$\mathrm{Zu}$ den mit PBS gewaschenen Immunpräzipitaten erfolgte die Zugabe von $50 \mu 1$ Polymerase-Master-Mix (4.1.1). Die Lücke im unvollständig doppelsträngigen HBV- 
Genom wird durch die Aktivität der Polymerase mit den im Polymerase-Master-Mix vorhandenen Nukleotiden (dATP, dGTP, dTTP, $\alpha^{32}$ PdCTP) aufgefüllt. Der Ansatz inkubierte für $12 \mathrm{~h}$ bei $37^{\circ} \mathrm{C}$. Anschließend wurden $50 \mu$ l Proteinase K-Mix zugemischt und für $30 \mathrm{~min}$ bei $37^{\circ} \mathrm{C}$ inkubiert, um die DNA von Proteinen zu lösen. Durch Phenol/Chloroform-Extraktion (4.2.2.3) und eine zweimalige $\mathrm{NH}_{4}$-Acetat/EthanolPräzipitation (0,4 Volumen $10 \mathrm{M}$ Ammoniumacetat und 2,5 Volumen Ethanol), Inkubation für 15 min bei RT, anschließende Zentrifugation bei $13000 \mathrm{UpM}$ für 15 min wurde die DNA von nicht eingebauten radioaktiven Nukleotiden befreit. Das Pellet wurde nach Trocknung in $10 \mu \mathrm{l}$ TE-Puffer und $2 \mu \mathrm{l}$ Probenauftragspuffer gelöst und einer Agarosegelelektrophorese (4.2.2.8) unterzogen. Anschließend wurde das Gel unter Vakuum und Hitze getrocknet und die radioaktiv markierte DNA durch Autoradiographie (4.2.4.8) detektiert.

\subsubsection{Anreicherung von Virionen durch CsCl-Dichtegradientenzentrifugation}

Zur Konzentrierung der Virionen aus $10 \mathrm{ml}$ Kulturüberstand und zur Trennung der kompletten Virionen von nicht umhüllten nackten Core-Partikeln wurde das klare Zellkulturmedium einer isopyknischen CsCl-Dichtegradientenzentrifugation unterzogen. Hierzu wurden 3,88 $\mathrm{g} \mathrm{CsCl}$ in $10 \mathrm{ml}$ Medium gelöst und in ein Quick-SealZentrifugenröhrchen überführt. Das Medium wurde mit Bayol F überschichtet, das Röhrchen luftblasenfrei verschweißt und für $48 \mathrm{~h}$ bei $45000 \mathrm{UpM}$ und $20^{\circ} \mathrm{C}$ im TI-70Rotor ultrazentrifugiert. Der gebildete CsCl-Gradient wurde anschließend in $2 \mathrm{ml}$ Fraktionen geteilt, wobei zunächst das Bayol-Öl zusammen mit $400 \mu 1$ vom oberen Teil des Gradienten verworfen wurden.

\subsubsection{Dichtebestimmung des CsCl-Gradienten}

Virionen haben eine Dichte von 1,24 g/ml, diejenige der nackten Core-Partikel beträgt 1,35 g/ml. Die Dichte der Fraktionen des CsCl-Gradienten (4.2.4.10) wurde im Refraktometer gemessen. Dazu wurde der Brechungsindex von $5 \mu \mathrm{l}$ der 2 ml-Fraktion bestimmt. Durch Vergleich mit den Werten einer für den Gradienten aufgestellten Tabelle konnte die Dichte der Fraktionen bestimmt und die Virionen enthaltende Fraktion erfaßt werden. 


\subsubsection{Dialyse von CsCl-Fraktionen}

Die 2 ml-Fraktionen aus der isopyknischen Dichtezentrifugation (4.2.4.10) wurden gegen PBS dialysiert, um das $\mathrm{CsCl}$ aus den Fraktionen zu entfernen. Hierfür wurden diese in Dialyseschläuche überführt, die zuvor nach Angaben des Herstellers für $15 \mathrm{~min}$ in $1 \mathrm{mM}$ Na-EDTA-Salzlösung, pH 7 gekocht wurden. Die Dialyse der Fraktionen erfolgte stets für 2-3 h bei RT. 


\section{Literaturverzeichnis}

[1] J. Summers, J.M.Smolenc, R. Snyder, Proc. Natl. Acad. Sci.USA,75, 4533 (1978).

[2] P.L. Marion, L.S. Oshiro, D.C. Regnery, G.H. Scullard, W.S. Robinson, Proc. Natl. Acad. Sci USA, 77, 2941 (1980).

[3] L.E. Lanford, D. Chavez, K.M. Brasky, R.B.Burns, R. Rico-Hesse, Proc. Natl. Acad. Sci. USA, 95, 5757 (2000).

[4] W.S. Mason, G. Seal, J. Summers, J. Virol., 36, 829 (1980).

[5] R. Sprengel, E.F. Kaleta, H. Will, J. Virol., 62, 3832 (1988).

[6] R. J. H. Payne, M.A. Nowak, B.S. Blumberg, Proc. Natl. Acad. Sci. USA, 93, 6542 (1996).

[7] R. P. Beasley, L.Y. Hwang, C.C. Lin, C.S. Chien, Lancet, II, 1129 (1981).

[8] P. Tiollais, C. Pourcel, A. Dejean, Nature, 317, 489 (1985).

[9] W. S. Robinson, D. A. Clayton, R.L. Greenman, J. Virol., 13, 384 (1974).

[10] P. M. Kaplan, R. L. Greenman, J. L. Gerin, R. H. Purcell, W. S. Robinson, J. Virol., 12, 995 (1973).

[11] (1) W. Stibbe, W. H. Gerlich, Virology, 123, 436 (1982).

(2) K.H. Heermann, U. Goldmann, W. Schwartz, T. Seyfarth, H. Baumgarten, W. H. Gerlich, J. Virol., 52, 396 (1984).

(3) A. R. Neurath, S. B. H. Kent, N. Strick, P. Taylor, C. E. Steavens, Nature, 315, 154 (1985).

[12] D. S. Dane, C. H. Cameron, M. Briggs, Lancet, I, 695 (1970). 
[13] C. J. Kim, J. G. Tilles, j. Clin. Invest., 52, 1176 (1970).

[14] D. R. Milich, G. B. Thornton, A. R. Neurath, S. B. Kent, M. L. Michel, p. Tiollais, F. V.Chisari, Science, 228, 1195 (1985).

[15] (1) A. Franco, M. Paroli, U. Testa, R. Benvenuto, C. Peschle, F. Balsano, V. Barnaba, J. Exp. Med., 175, 1195 (1992).

(2) A. Budowska, P. Bedossa, F. Groh, A. Louise, J. Pillot, J. Virol., 69, 840 (1995).

(3) H. Mehdi, X. Yang, M. E. Peebles, Virology, 217, 58 (1996).

[16] R. J. Rigg, H. Schaller, J. Virol., 66, 2829 (1992).

[17] C. T. Bock, S. Schwinn, C. H. Schroder, I. Velhagen, H. Zentgraf, Virus-Genes, 12, 53 (1996).

[18] M. Kann, A. Bischof, W. H. Gerlich, J. Virol., 71, 4 (1997).

[19] J. Köck, H. J. Schlicht, J. Virol., 67, 4867 (1993).

[20] H. Will, W. Reiser, T. Weimer, E. Pfaff, M. Büscher, R. Sprengel, R. Cattaneo, H. Schaller, J. Virol., 61, 904 (1987).

[21] M. Junker-Niepmann, R. Bartenschlager, H. Schaller, EMBO J., 9, 3389 (1990).

[22] J. Summers, W.S. Mason, Cell, 29, 403 (1982).

[23] M. Nassal, H. Schaller, J. Viral Hepat, 3, 217 (1996).

[24] J. Tuttleman, C. Pourcel, J. Summers, Cell, 47, 451 (1986).

[25] T. Gerelsaikhan, J.E. Tavis, V. Bruss, J. Virol., 70, 4269 (1996).

[26] (1) V. Bruss, W. H. Gerlich, Virology, 163, 268 (1988).

(2) D. N. Standring, W. J. Rutter, H. E. Varmus, D. Ganem, J. Virol., 50, 563 (1984). 
[27] J. Wang, A. S. Lee, J. H. Ou, J. Virol., 65, 5080 (1991).

[28] (1) M. R. Brunetto, M. Stemmler, F. Schödel, H. Will, A. Ottobrelli, M. Rizetto, F. Bonino, Ital. J. Gastroenterol., 21, 151 (1989).

(2) M. R. Brunetto, M. M. Giarin, F. Oliveri, E. Chiaberge, M. Baldi, A. Alfarano, A. Serra, G. Saracco, H. Will, F. Bonino, Proc. Natl. Acad. Sci. USA, 88, 4186 (1991).

[29] D. R. Milich, J. Jones, J. L. Hughes, J. Price, A. K. Rayney, A. McLachlan, Proc. Natl. Acad. Sci. USA, 87, 6599 (1990).

[30] (1) A. Gallina, G. Bonelli, I. Zentilin, G. Rindi, M. Muttini, G. Milanesi, J. Virol., 63, 4645 (1989).

(2) F. Birnbaum, M. Nassal, J. Virol., 64, 3319 (1990).

[31] M. A. Petit, J. Pillot, J. Virol., 53, 543 (1985).

[32] (1) M. Feitelson, P. L. Marion, W. S. Robinson, J. Virol., 43, 741 (1982).

(2) W. H. Gerlich, U. Goldmann, R. Müller, W. Stibbe, W. Wolff, J. Virol. , 42, 761 (1982).

[33] H. J. Schlicht, R. Bartenschlager, H. Schaller, J. Virol., 63, 2995 (1989).

[34] A. Machida, H. Ohnuma, F. Tsuda, A. Yoshikawa, Y. Hoshi, T. Tanaka, S. Kishimoto, Y. Akahane, Y. Miyakawa, M. Mayumi, J. Virol., 65, 6024 (1991).

[35] M. Yu, J. Summers, J. Virol., 68, 4341 (1994).

[36] (1) C. T. Yeh, J. H. Ou, J. Virol., 65, 2327 (1991).

(2) M. Kann, W. H. Gerlich, J. Virol. , 68, 7993 (1994).

[37] R. Bartenschlager, H. Schaller, EMBO J., 11, 3413 (1992).

[38] B. J. Cohen, J. E. Richmond, Nature, 296, 677 (1982). 
[39] R. E. Lanford, L. Notvall, Virology, 176, 222 (1990).

[40] R.A. Crowther, N. A. Kiselev, B. Böttcher, J. A. Berriman, G. P. Borisova, V. Ose, P.Pumpens, Cell, 77, 943 (1994).

[41] J. Salfeld, E. Pfaff, M. Noah, H. Schaller, J. Virol., 63, 798 (1989).

[42] P. Pushko, M. Sällberg, G. Borisova, U. Ruden, V. Bichko, P. Vahren, P. Pumpens, L. Magnius, Virology, 202, 912 (1994).

[43] H. J. Schlicht, R. Bartenschlager, H. Schaller, J. Virol., 63, 2995 (1989).

[44] M. Nassal, J. Virol., 66, 4107 (1992).

[45] M. Seifer, D. N. Standring, J. Virol., 68, 5548 (1994).

[46] S.A. Wynne, R.A. Crowther, A.G. Leslie, Mol.Cell., 3, 771 (1999).

[47] J. F. Conway, N. Cheng, A. Zlotnik, P. T. Wingfield, S. J. Stahl, A. C. Steven, Nature, 386, 91 (1997).

[48] B. E. Eble, V. R. Lingappa, D. Ganem, Mol. Cell. Biol., 6, 1454 (1986).

[49] D. N. Peterson, J. Biol. Chem., 256, 6975 (1981).

[50] B. E. Eble, V. R. Lingappa, D. Ganem, J. Virol., 64, 1414 (1990).

[51] P. Valenzuela, M. Quiroga, J. Zaldivar, P. Gray, W. J. Rutter, Animal virus genetics, Acad. .Press, Inc., New York, 57 (1980).

[52] K. H. Heermann, U. Goldmann, W. Schwartz, T. Seyfarth, H. Baumgarten, W.H.Gerlich, J. Virol., 52, 396 (1984).

[53] (1) P. Ostapchuk, P. Hearing, D. Ganem, EMBO J., 13, 1048 (1994). 
(2) V. Bruss, K. Vieluf, J. Virol., 69, 6652 (1995).

(3) R. Prange, R. E. Streeck, EMBO J., 14, 247 (1995).

[54] V. Bruss, X. Lu, R. Thomssen, W. H. Gerlich, EMBO J., 13, 2273 (1994).

[55] (1) P. M. Kaplan, R. L. Greesman, J. L. Gerin, R. H. Purcell, W. S. Robinson, J Virol., 12, 995 (1973).

(2) W. H. Gerlich, W. S. Robinson, Cell, 21, 801 (1980).

[56] V. Bruss, D. Ganem, Proc. Natl. Acad. Sci., 88, 1059 (1991).

[57] V. Bruss, R. Thomssen, J. Virol., 68, 1643 (1994).

[58] K. Vieluf, Dissertation Göttingen, 1998.

[59] V. Bruss, J. Virol., 71, 9359 (1997).

[60] K. C. Cheng, G. L. Smith, B. Moss, J. Virol., 60, 337 (1986).

[61] H. Löffler-Mary, J. Dumortier, C. Klentsch-Zimmer, R. Prange, Virology, 270, 358 (2000).

[62] H. Garoff, R. Hewson, D.-J. E. Opstelten, Microbiol. Mol. Biol. Rev., 62, 1171 (1998).

[63] M. Suomalainen, P. Liljeström, H. Garoff, J. Virol., 66, 4737 (1992).

[64] R. Prange, R. Nagel, R. E. Streeck, J. Virol., 66, 5832 (1992).

[65] K. Ueda, T. Tsurimoto, K. Matsubara, J. Virol., 65, 3521 (1991).

[66] F. Poisson, A. Severac, C. Hourioux, A. Goudeau, P. Roingeard, Virology, 228, 115 (1997)

[67] F. R. Clayton, A. Owsianka, H. A. Patel, J.Gen.Virol., 82, 1533 (2001). 
[68] G. Wunderlich, Dissertation Göttingen, (1994).

[69] D. Hanahan, J. Mol. Biol., 166, 557 (1983).

[70] Y. Gluzman, Cell, 23, 175 (1980).

[71] H. Nakabayashi, K. Taketa, K, Miyano, T. Yamane, J. Sato, Cancer Res., 42, 3858 (1982).

[72] H. C. Birnboim, J. Doly, Nucleic Acids Res., 7, 1513 (1979).

[73] D. Ish-Horowicz, J. F. Burke, Nucleic Acids Res., 9, 2989 (1981).

[74] J. Sambrook, E. F. Fritsch, T. Maniatis, Molecular Cloning,, Cold Spring Harbor Laboratory Press, $\mathbf{1 . 4 0}$ (1989).

[75] H. A. Ehrlich, PCR Technology, Stockton Press, New York,(1989).

[76] F. Sanger, S. Nicklen, A. R. Coulsou, Proc. Natl, Acad. Sci,USA, 74, 5463 (1977).

[77] U. K. Laemmli, Nature, 227, 680 (1984). 


\section{Abbildungsverzeichnis}

Abbildung 1.1: Infektionszyklus des Hepatitis B Virus .....................................................

Abbildung 1.2 Modell des HBV Corepartikels (modifiziert) ............................................. 7

Abbildung 1.3: Darstellung der transmembranen Topologien der HBV-Hüllproteine .........9

Abbildung 2.1: Behandlung linearisierter DNA mit der Exonuklease Bal3 ........................ 12

Abbildung 2.2: Darstellung des Expressionsvektors pSVL.............................................. 13

Abbildung 2.3: Restriktionsanalyse einer Auswahl der durch Exonuklease Bal31 veränderten Plasmide .............................................................................. 14

Abbildung 2.4: Schematische Darstellung des Exonuklease-Abbaus ................................... 15

Abbildung 2.5: Nachweis ${ }^{35}$ S-markierter verkürzter L-Proteine nach Transfektion

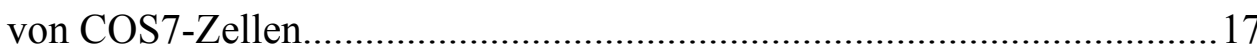

Abbildung 2.6: Nachweis der Hüllproteinexpression nach Cotransfektion von COS7-Zellen

Abbildung 2.7: Amplifikation verschieden großer Fragmente aus pSVL mittels PCR 21

Abbildung 2.8: Nachweis der durch PCR verkürzten L-Proteine nach Transfektion von COS7-Zellen.

Abbildung 2.9: Nachweis der aus Zellmedium und-lysat immunpräzipitierten deletierten L-Proteine nach Cotransfektion von COS7-Zellen .24

Abbildung 2.10 a: Endogene Polymerasereaktion nach Cotransfektion von HuH7-Zellen (Lysate). 26

Abbildung 2.10 b: Endogene Polymerasereaktion nach Cotransfektion von HuH7-Zellen (Zellkulturüberstände)

Abbildung 2.11: Nachweis von Virionen nach Transfektion von HuH7-Zellen durch CsCl-Dichtegradientenzentrifugation und endogener Polymerasereaktion

Abbildung 2.12: Nachweis deletierter L-Proteine nach Transfektion von COS7-Zellen 33

Abbildung 2.13: Nachweis der L-Proteinbildung in Zelllysat und -medium von COS7-Zellen nach Cotransfektion mit pSVBX24H 
Abbildung 2.14 a: Nukleokapsid-Nachweis aus Zelllysaten von HuH7-Zellen .36

Abbildung 2.14 b: Nachweis von Virionen aus dem Zellmedium transfizierter HuH7-Zellen 37

Abbildung 2.15: Übersicht über alle erzeugten und in COS7-Zellen phänotypisch charakterisierten L-Konstrukte 40

Abbildung 2.16: Modell der in Wechselwirkung tretenden Domänen von L-Protein und Nukleokapsid. 


\section{Tabellenverzeichnis}

Tabelle 2.1: Erzeugung von L-Konstrukten mit entsprechend ausgewählten Primern für das 5 '-Ende.........................................................20

Tabelle 2.2: Temperaturprogramm für die PCR …..........................................................20

Tabelle 2.3: Ergebnisübersicht aller getesteten Konstrukte..............................................30

Tabelle 4.1: Didesoxyribonukleotide (ddNTP) und die entsprechenden Rhodamin-Fluoreszenzfarbmarkierungen .67 


\section{Danksagung}

Herrn Prof. Dr. Thomssen und Herrn Prof. Dr. O. Götze danke ich für die freundliche Bereitstellung des Arbeitsplatzes im Hygiene-Institut Göttingen in der Abteilung Medizinische Mikrobiologie und ihre Unterstützung.

Für die Bereitschaft, das Erstreferat zu übernehmen, danke ich Herrn Prof. Dr. A. Zeeck.

Mein Dank gilt Herrn PD Dr. V. Bruß für die Themenstellung und für sein stetes Interesse am Fortgang meiner Arbeit.

Meinen besonderen Dank möchte ich Herrn Prof. Dr. O. Götze aussprechen, ohne dessen Gewährung von finanzieller Unterstützung die Fertigstellung dieser Arbeit nicht möglich gewesen wäre.

Allen Mitarbeitern des Arbeitskreises von Herrn PD Dr. Bruß möchte ich für ein angenehmes Arbeitsklima und ihre stete Hilfsbereitschaft danken. Mein besonderer Dank gilt meinem Kollegen Dirk Ponsel, der mir bei der Bedienung einiger Graphikprogramme mit Rat und Tat zur Seite stand.

Allen meinen Freunden und meiner Schwester Alex möchte ich für die angenehme Ablenkung während der Anfertigung dieser Arbeit danken

Nicht zuletzt gilt mein Dank meinem Freund Jens, sowie meinen Eltern, die mir den Rücken gestärkt und freigehalten haben. 


\section{Lebenslauf}

Name:

Geburtstag:

Geburtsort:

Staatsangehörigkeit:

\section{Schulbildung}

1975-1979

1979-1985

1985-1988

$6 / 1988$

\section{Studium}

$10 / 1988$

$7 / 1994$

6/1996-3/1997

$4 / 1997$

8/1997-3/2002

$2 / 2000-3 / 2002$

$9 / 2000-2 / 2002$
Michaela Schläger

15.11.1968

Kassel

deutsch

Grundschule Mergellstrasse in Kassel

Gymnasium Heinrich-Schütz-Schule in Kassel

Oberstufengymnasium Jacob-Grimm-Schule in Kassel

Erwerb der allgemeinen Hochschulreife

Aufnahme des Diplomstudienganges Chemie an der

Georg-August-Universität Göttingen

Diplomvorprüfung

Anfertigung der Diplomarbeit am Institut für Organische

Chemie im Arbeitskreis von Prof. Dr. L- Fitjer mit dem

Thema „, Experimentelle Überprüfung potentieller

Umlagerungswege zu $\Delta^{9,12}$-Capnellen“

Diplomprüfung

Wissenschaftliche Hilfskraft am Institut für Medizinische

Mikrobiologie

Anfertigung der vorliegenden Arbeit mit dem Thema

„Bedeutung des cytosolischen Teils des großen Hüllproteins

für die Umhüllung des Hepatitis B Nukleokapsids“" unter der Anleitung von Prof. Dr. med. R. Thomssen

Anstellung als Aushilfskraft bei der Firma Develogen,

Rudolf-Wissell-Str.28 in Göttingen 